ORNL/TM-12344

Dist. Category UC-530

Engineering Technology Division

\title{
ALMR Deployment Economic Analysis
}

\author{
J. G. Delene \\ L. C. Fuller \\ C. R. Hudson
}

June 1993

This document contains information of a preliminary nature. It is subject to revision or correction and therefore does not represent a final report.

Prepared by

OAK RIDGE NATIONAL LABORATORY

Oak Ridge, Tennessee 37831-6285

managed by

MARTIN MARIETTA ENERGY SYSTEMS, INC.

for the

U.S. DEPARTMENT OF ENERGY under contract DE-ACO5-84OR21400
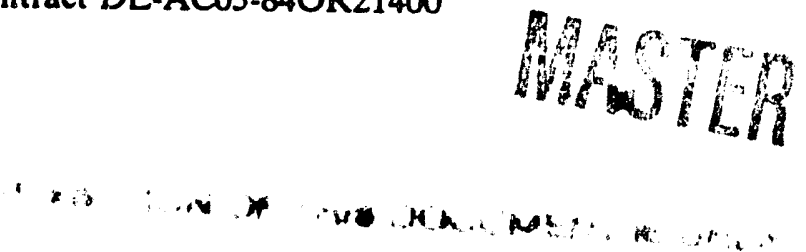
CONTENTS

EXECUTTVE SUMMARY $\ldots \ldots \ldots \ldots \ldots \ldots \ldots \ldots \ldots \ldots \ldots \ldots \ldots \ldots \ldots \ldots$

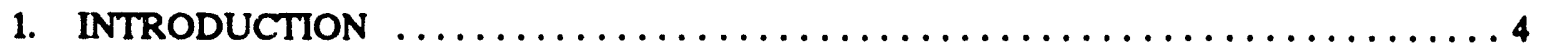

1.1 DEPLOYMENT ECONOMICS MODEL $\ldots \ldots \ldots \ldots \ldots \ldots \ldots \ldots \ldots \ldots$

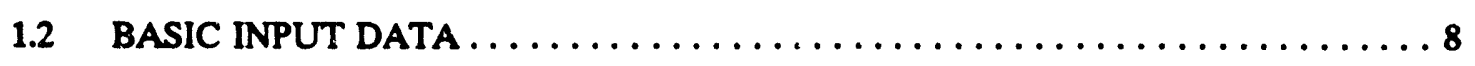

1.3 INPUT VARIATIONS $\ldots \ldots \ldots \ldots \ldots \ldots \ldots \ldots \ldots \ldots \ldots \ldots \ldots \ldots, 18$

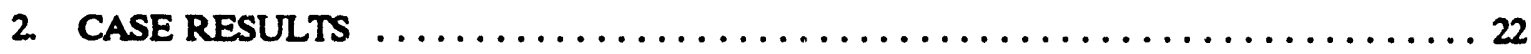

2.1 NO ALMR CASE $\ldots \ldots \ldots \ldots \ldots \ldots \ldots \ldots \ldots \ldots \ldots \ldots \ldots \ldots \ldots \ldots \ldots \ldots \ldots \ldots \ldots, 22$

2.2 BASE ALMR BURNER $\ldots \ldots \ldots \ldots \ldots \ldots \ldots \ldots \ldots \ldots \ldots \ldots \ldots \ldots \ldots \ldots \ldots \ldots \ldots, 22$

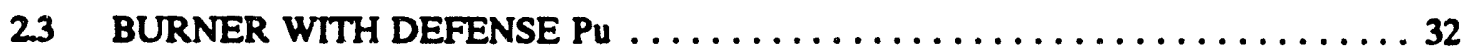

24 MAXIMUM DEPLOYMENT OF BURNER $\ldots \ldots \ldots \ldots \ldots \ldots \ldots \ldots \ldots, 32$

2.5 BURNER AT 75\% CAPACITY FACTOR $\ldots \ldots \ldots \ldots \ldots \ldots \ldots \ldots \ldots \ldots \ldots \ldots \ldots \ldots, 32$

2.6 BURNER AT 80\% CAPACITY FACTOR $\ldots \ldots \ldots \ldots \ldots \ldots \ldots \ldots \ldots \ldots \ldots \ldots \ldots \ldots$

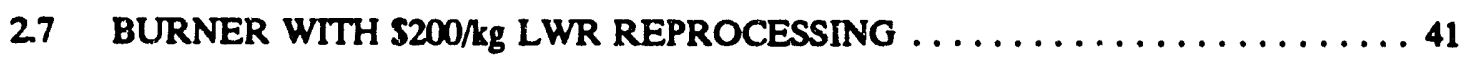

2.8 BURNER WITH S1000/kg LWR REPROCESSING $\ldots \ldots \ldots \ldots \ldots \ldots \ldots \ldots 41$

2.9 BURNER WITH 0.5 WASTE EQUIVALENT MASS FACTOR . . . . . . . . . 41

2.10 BURNER WITH 0.5 REPOSITORY DISPOSAL COST FACTOR ......... 41

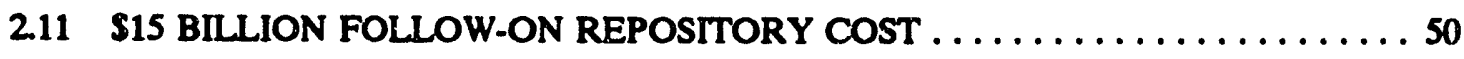

2.12 LWR REPROCESSING COST INCLUDED WITH WASTE SYSTEM ....... 50

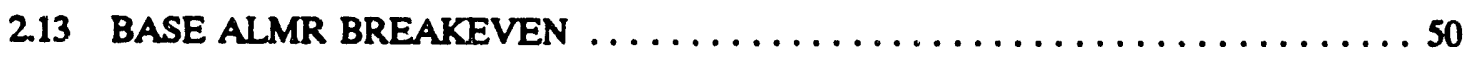

2.14 MAXIMUM DEPLOYMENT OF BREAKEVEN PLANT $\ldots \ldots \ldots \ldots \ldots \ldots .58$

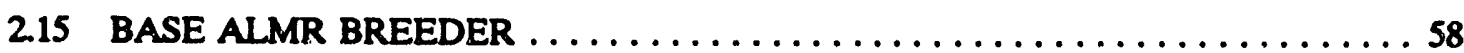

2.16 BREEDER PLANT WITH DEFENSE Pu $\ldots \ldots \ldots \ldots \ldots \ldots \ldots \ldots \ldots, 58$

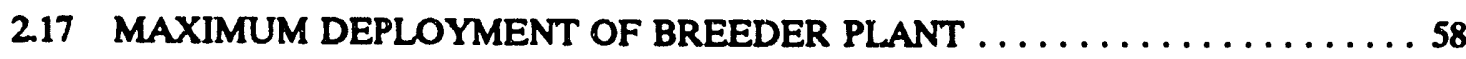

2.18 NO UTILIZATION OF INITIAL LWR SPENT FUEL STOCKS . . . . . . . . 59

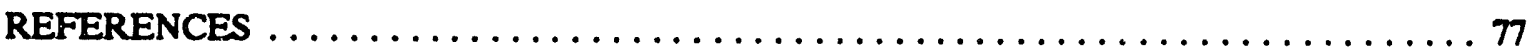

Appendix A. SPREADSHEET CASE NAMES $\ldots \ldots \ldots \ldots \ldots \ldots \ldots \ldots \ldots \ldots \ldots$

Appendix B. SPREADSHEET ROW DESCRIPTIONS $\ldots \ldots \ldots \ldots \ldots \ldots \ldots \ldots$ 


\section{LIST OF FIGURES}

Figure

Page

E.1. Equivalent heavy metal disposed of in repository: base case $\ldots \ldots \ldots \ldots \ldots \ldots \ldots 3$

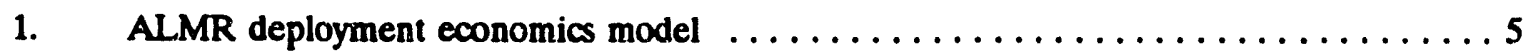

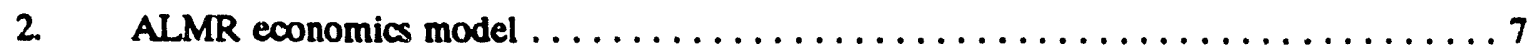

3. Annual energy generation, no ALMR case $\ldots \ldots \ldots \ldots \ldots \ldots \ldots \ldots \ldots \ldots$

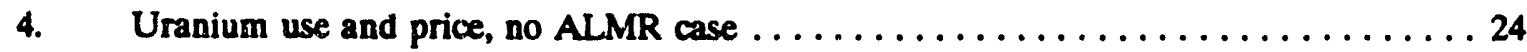

5. Equivalent heavy metal disposed of in repository, no ALMR case $\ldots \ldots \ldots \ldots \ldots 25$

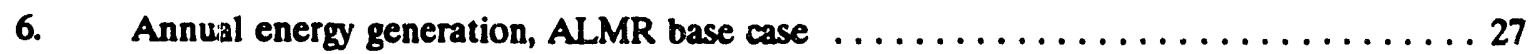

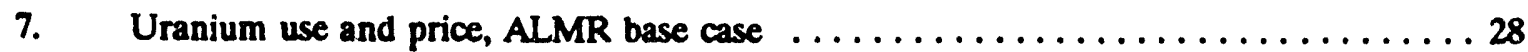

8. Equivalent heavy metal disposed of in repository, ALMR base case . . . . . . . . 29

9. Annual energy generation, ALMR breeder base case $\ldots \ldots \ldots \ldots \ldots \ldots \ldots \ldots$

10. Uranium use and price, ALMR breeder base case $\ldots \ldots \ldots \ldots \ldots \ldots \ldots \ldots \ldots$

11. Equivalent heavy metal disposed of in repository,

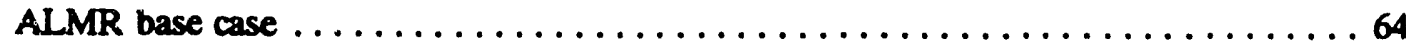

12. Annual energy generation, ALMR breeder maximum deployment $\ldots \ldots \ldots \ldots \ldots 9$

13. Uranium use and price, ALMR breeder maximum deployment $\ldots \ldots \ldots \ldots \ldots \ldots \%$

14. Equivalent heavy metal disposed of in repository,

ALMR breeder maximum deployment $\ldots \ldots \ldots \ldots \ldots \ldots \ldots \ldots \ldots \ldots \ldots$

15. Equivalent heavy metal disposed of in repository $\ldots \ldots \ldots \ldots \ldots \ldots \ldots \ldots$ 


\section{LIST OF TABLES}

Table

Page

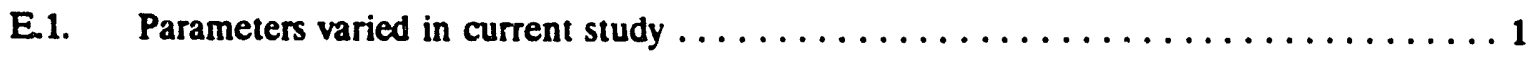

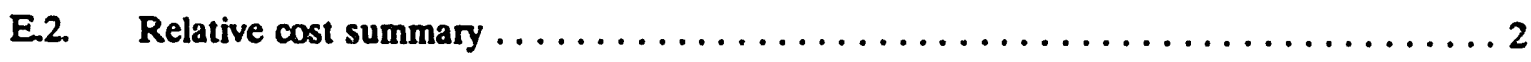

1. General information $\ldots \ldots \ldots \ldots \ldots \ldots \ldots \ldots \ldots \ldots \ldots \ldots \ldots$

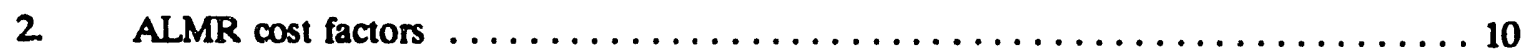

3. ALMR fuel cycle parameters $\ldots \ldots \ldots \ldots \ldots \ldots \ldots \ldots \ldots \ldots \ldots \ldots \ldots \ldots \ldots$

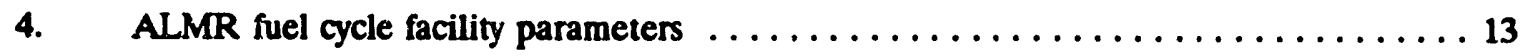

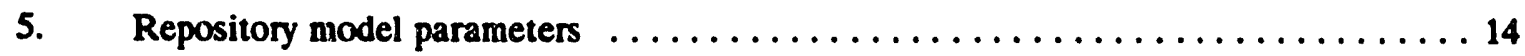

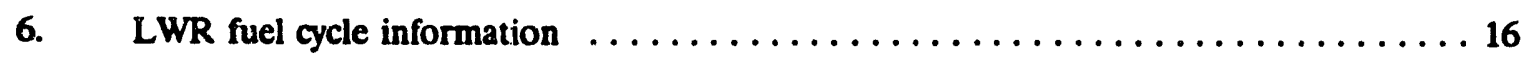

7. LWR fuel cycle parameters $\ldots \ldots \ldots \ldots \ldots \ldots \ldots \ldots \ldots \ldots \ldots \ldots \ldots \ldots$

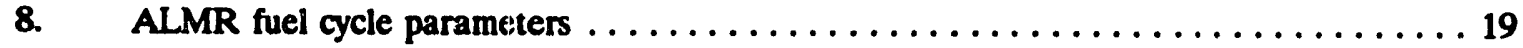

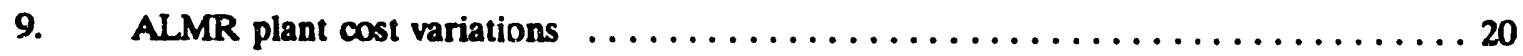

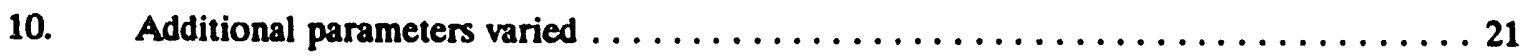

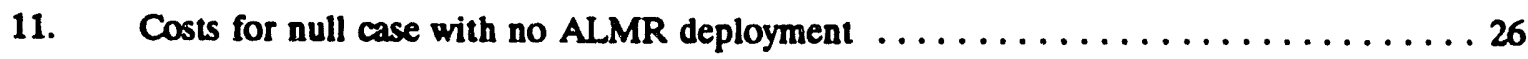

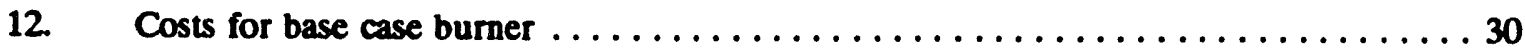

13. Cost summary: ALMR base case burner vs no ALMR case $\ldots \ldots \ldots \ldots \ldots \ldots \ldots$

14. Costs for burner with defense-related plutonium $\ldots \ldots \ldots \ldots \ldots \ldots \ldots \ldots \ldots$

15. Cost summary: ALMR burner with defense plutonium vs no ALMR case $\ldots \ldots \ldots 34$

16. Costs for burner with maximum deployment rate $\ldots \ldots \ldots \ldots \ldots \ldots \ldots \ldots$

17. Cost summary: ALMR burner with maximum deployment rate

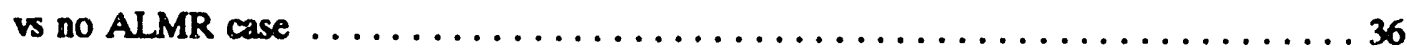

18. Costs for base case convertor with low (75.25\%) capacity factor $\ldots \ldots \ldots \ldots \ldots$

19. Cost summary: ALMR burner with low capacity factor vs no ALMR case $\ldots \ldots \ldots 38$

20. Costs for base case convertor with medium (80.63\%) capacity factor . . . . . . . 39

21. Cost summary: ALMR burner with medium capacity factor

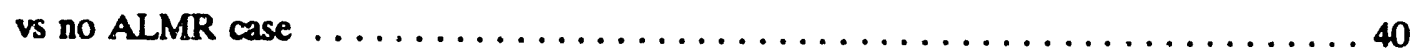

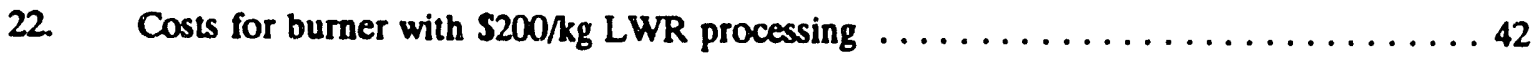

23. Cost summary: ALMR burner with $\$ 200 / \mathrm{kg}$ LWR processing

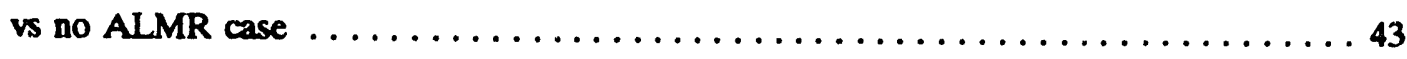

24. Costs for burner with $\$ 1000 / \mathrm{kg}$ LWR processing $\ldots \ldots \ldots \ldots \ldots \ldots \ldots \ldots$ 
25. Cost summary: ALMR burner with $\$ 1000 / \mathrm{kg}$ LWR processing

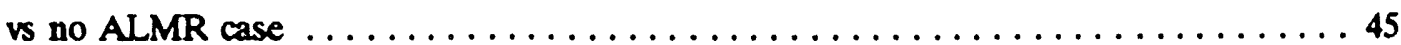

26. Costs for burner with 0.5 waste equivalent mass factor $\ldots \ldots \ldots \ldots \ldots \ldots \ldots \ldots$

27. Cost summary: ALMR burner with 0.5 waste equivalent mass factor

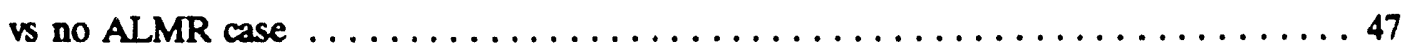

28. Costs for burner with 0.5 repository disposal cost factor $\ldots \ldots \ldots \ldots \ldots \ldots \ldots \ldots$

29. Cost summary: ALMR burner with 0.5 repository disposal cost factor

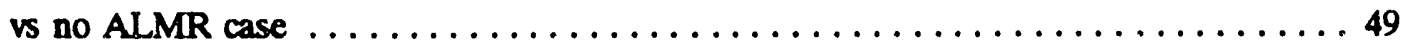

30. Costs for $\$ 15$ billion repository costs with no ALMR deployment $\ldots \ldots \ldots \ldots \ldots 51$

31. Costs for $\$ 15$ billion repository costs with ALMR burner deployment $\ldots \ldots \ldots \ldots 52$

32. Cost summary: ALMR burner vs no ALMR case for $\mathbf{S 1 5}$ billion

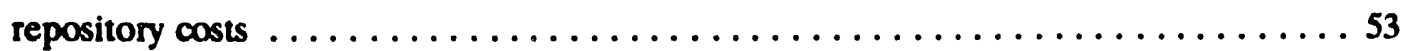

33. Costs with $L W R$ processing charge in repository costs $\ldots \ldots \ldots \ldots \ldots \ldots \ldots \ldots$

34. Cost summary: ALMR burner vs no ALMR case for $L W R$ processing

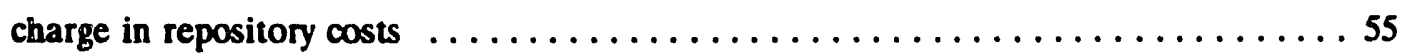

35. Costs for breakeven breeder with base parameters $\ldots \ldots \ldots \ldots \ldots \ldots \ldots \ldots \ldots$

36. Cost summary: ALMR breakeven breeder with base parameters

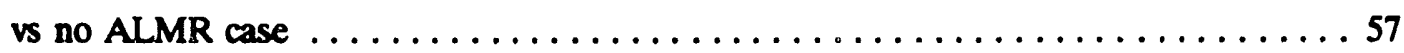

37. Costs for base case breakeven breeder with maximum deployment $\ldots \ldots \ldots \ldots \ldots 6$

38. Cost summary: base case breakeven breeder with maximum deployment

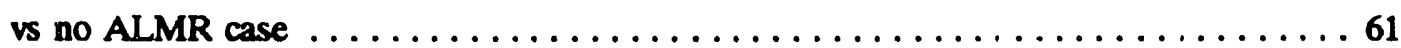

39. Costs for base ALMR breeder, breeding ratio $=1.24 \ldots \ldots \ldots \ldots \ldots \ldots \ldots \ldots$

40. Cost summary: base ALMR breeder vs no ALMR case $\ldots \ldots \ldots \ldots \ldots \ldots \ldots 6$

41. Costs for base ALMR breeder with defense plutonium $\ldots \ldots \ldots \ldots \ldots \ldots$

42. Cost summary: ALMR breeder with defense plutonium vs no ALMR case $\ldots \ldots \ldots 68$

43. Costs for ALMR breeder with maximum deployment rate $\ldots \ldots \ldots \ldots \ldots \ldots \ldots 72$

44. Cost summary: ALMR breeder with maximum deployment rate

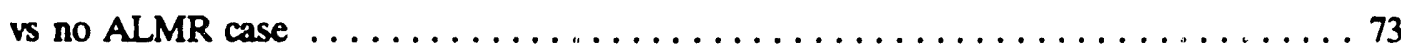

45. Costs for ALMR burner with no utilization of initial spent

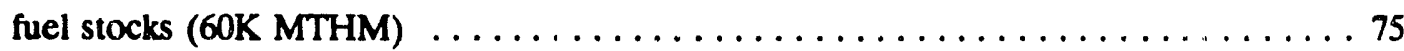

46. Cost summary: ALMR burner with no utilization of spent fuel stocks

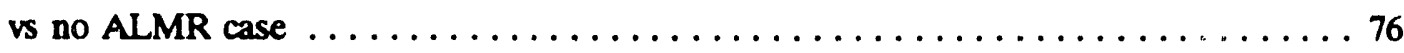

viii 


\section{EXECUTTVE SUMMARY}

This analysis seeks to model and evaluate the economics of the use of Advanced Liquid Metal Reactors (ALMR) as a component of this country's future electricity generation mix. The ALMR concept has the ability to utilize as fuel the fissile material contained in previously irradiated nuclear fuel (i.e., spent fuel). While not a requirement for the successful deployment of ALMR power plant technology, the reprocessing of spent fuel from light water reactors (LWR) is necessary for any rapid introduction of ALMR power plants. In addition, the reprocessing of LWR spent fuel may reduce the number of high level waste repositories needed in the future by burning the long-lived actinides produced in the fission process. With this study, the relative economics of a number of potential scenarios related to these issues are evaluated. While not encompassing the full range of all possibilities, the cases reported here provide an indication of the potential costs, timings, and relative economic attractiveness of ALMR deployment.

The model used to evaluate the ALMR deployment economics was developed by the Engineering Economic Evaluations Group at Oak Ridge National Laboratory. The model calculates year-by-year costs, net present value costs, and levelized generation costs during an analysis period of 2010-2070. Developed in Lotus spreadsheet format, the analysis reflects the deployments of ALMR and LWR power plants, ALMR fuel recycle facilities, LWR reprocessing facilities, and high-level waste repositories. Data used in the model were supplied by the DOE ALMR program participants.

As mentioned above, several cases have been evaluated. Three reactor core designs (burner, breakeven, breeder) reflecting different fuel utilization strategies were considered. In addition, other parameters were varied individually as shown in Table E.1.

Table E1. Parameters varied in current study

\begin{tabular}{lcl}
\hline \multicolumn{1}{c}{ Item } & $\begin{array}{c}\text { Base } \\
\text { Parameters }\end{array}$ & Parameter Variations \\
\hline Deploy ALMRs & Yes & No (null case) \\
Nominal capacity factor & 0.86 & $0.80,0.75$ \\
ALMR power in 2030, Gwe & 27 & Max achievable \\
Conversion/breeding ratio & 0.69 & $1.04,1.25$ \\
Pu available from weapons, MT & 0 & 100 \\
LWR fuel recovery cost, S/kgHM & 350 & 200,1000 \\
Cost to implement repository, SB & 7.2 & 15 \\
LWR processing waste & & \\
$\quad$ repository load factor & 0.25 & 0.5 \\
$\quad$ repository cost factor & 0.75 & Yes \\
LWR fuel processing costs & & No \\
charged to repository & &
\end{tabular}

-Parameters varied one at a time from base parameter set. 
In addition to calculating the year-by-year absolute costs for each case, a relative comparison to a null case, where no ALMRs are deployed and all nuclear generation is supplied by once-through uranium burning plants, was made. This provides a useful relative measure of the economic attractiveness of the various scenarios. The results of the comparison are shown in Table E.2, ordered in ascending economic benefit. The values shown in the table represent the economic benefit or savings (or penalty for the one negative value) relative to the null, no ALMR, case. The values in Table E. 2 are the differences in net present value between a particular ALMR case and the null case over the period 2010-2070. The wide range of $\$ 92$ billion (1992\$) indicates the economic sensitivity to particular assumptions. The $\$ 44$ billion penalty, if $\$ 1,000 / \mathrm{Kg} \mathrm{HM}$ processing costs are assumed, demonstrates the very sensitive nature of the LWR reprocessing cost assumption. At the other extreme, the breeding of additional fissile material within the ALMR permits additional ALMR plants to be deployed, thereby displacing uranium-burner plants, reducing the amount of LWR fuel to reprocess, reducing the upward price pressure on uranium ore, and making the existing uraniumburners cheaper to run.

Table E2 Relative cost summary

\begin{tabular}{lc}
\hline \multicolumn{1}{c}{ Case } & $\begin{array}{c}\text { Relative } \\
\text { Net present value } \\
2010-2070 \\
\text { (Billions } 1992 \$)\end{array}$ \\
\hline Burner with \$1000/kg LWR reprocessing & -43.74 \\
No utilization of initial LWR spent fuel stocks (60,000 MTHM) & 12.52 \\
Maximum deployment of base case burner & 14.09 \\
Burner at 75\% capacity factor & 14.99 \\
Burner at 80\% capacity factor & 16.30 \\
Base case ALMR burner & 16.63 \\
ALMR breakeven (breeding ratio = 1.04) & 19.54 \\
Maximum deployment of breakeven plant & 20.74 \\
LWR reprocessing cost included with waste system & 21.92 \\
Burner with defense Pu & 23.12 \\
Burner with \$200/kg LWR reprocessing & 30.57 \\
ALMR breeder (breeding ratio = 1.24) & 41.41 \\
Maximum deployment of breeder plant & 46.82 \\
Breeder plant with defense Pu & 48.10 \\
\hline
\end{tabular}

${ }^{a}$ Benefits compared to no ALMR case (null case).

One of the most striking observations of this set of cases involves the reduction in the number of repositories when ALMR plants are deployed. Because reprocessing removes the long-lived actinides (and their associated thermal load) from inclusion in a repository, more non-actinide material may be placed in the repository, thereby increasing the effective capacity of a repository. Figure E.1 shows the effective repository loading as a function of time for no ALMR deployment and the base case ALMR deployment. In the base case, the repository is assumed to accommodate four times the material in terms of initial heavy metal if the actinides are removed from the spent fuel. It is the Department of Energy's position that under no case does ALMR deployment displace the need for the first high-level waste repository and disposal of the current unprocessed spent fuel in that repository. The analysis in this study is focused on describing a range of economic performance using the stated assumptions. The study does not attempt to characterize likely or preferred deployment strategies. 


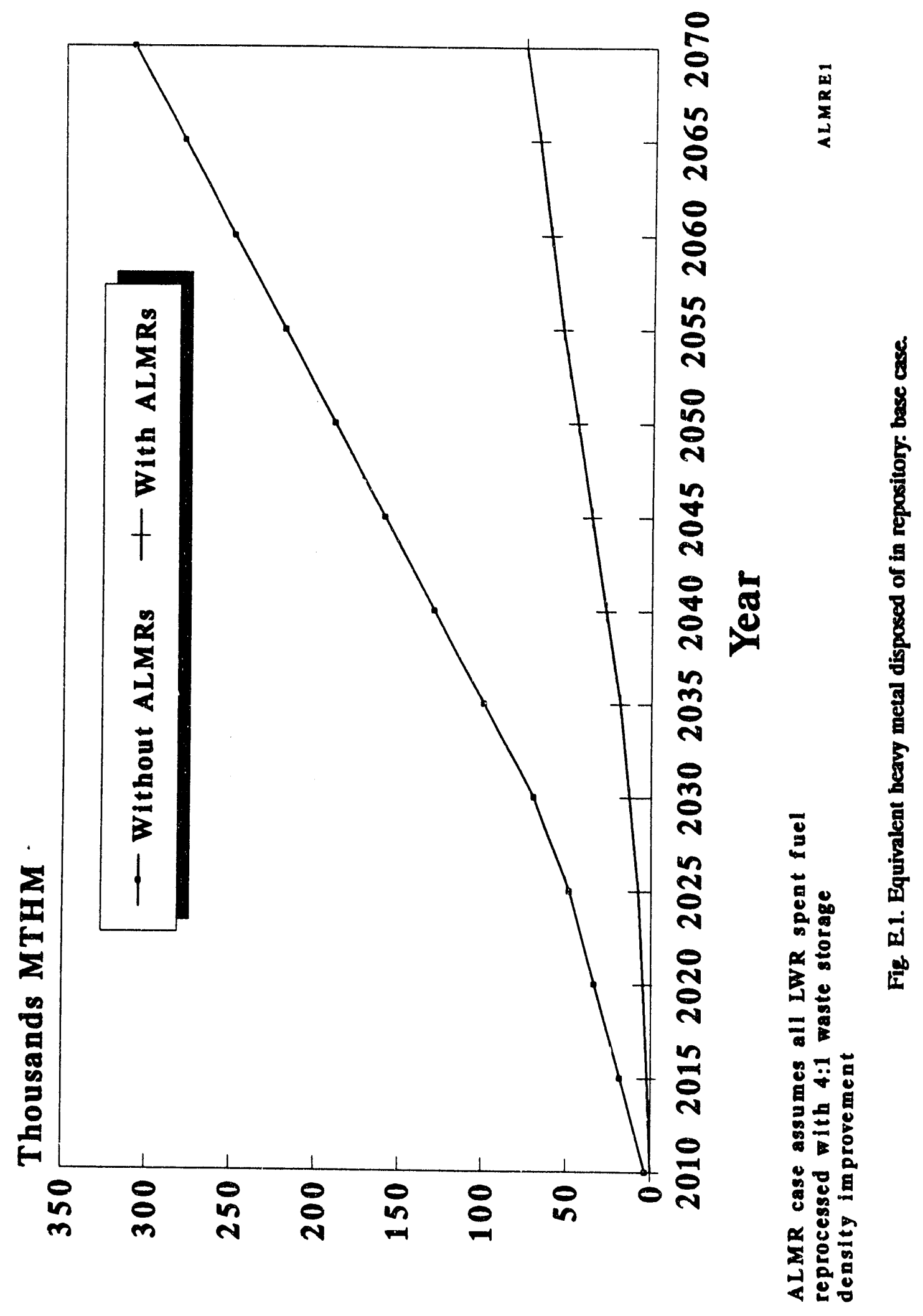




\section{INTRODUCTION}

Determining the relative economic value of various nuclear fuel cycle alternatives is an involved process. For cases that include fuel reprocessing, multiple potential sources of fissile material, and the determination of repository impacts, the model, by necessity, becomes large and complex. The Engineering Economic Evaluations Group at Oak Ridge National Laboratory was asked by the Department of Energy to develop an Advanced Liquid Metal Reactor (ALMR) deployment economics model and assess various cases of ALMR deployment. This report describes the model, and the input and results of several alternative scenarios.

\subsection{DEPLOYMENT ECONOMICS MODEL}

The ALMR deployment economics model combines ALMR deployment, fuel cycle logistics, and high level waste repository logistics together with cost information, cash flow and revenue requirements methodology to obtain year-by-year costs and levelized power generation costs under various scenarios of ALMR deployment. The model is implemented in a Lotus 123 spreadsheet. The current model starts with the first commercial ALMR deployment in the year 2010 and provides ALMR deployment and year-by-year cosis through the year 2070. A line-by-line description of the spreadsheet is given in Appendix B.

A pictorial description of the model is shown in Fig. 1. The ALMR is introduced into a nuclear power generation economy consisting of light water reactors (LWR). The maximum rate of ALMR deployment depends on the availability of fissile material which in turn depends on the reprocessing capacity and the quantity of spent LWR fuel available. The total nuclear power generation in any given year is that projected in the National Energy Strategy (NES) with extrapolations to the year 2070. Power not produced by ALMRs is assumed to come from LWRs. LWR spent fuel may either be disposed of directly or it can be reprocessed to obtain start-up fuel for ALMRs. An ALMR economy cannot exist without a source of start-up fuel. Actinides recovered from LWR spent fuel is a prime source for this material. Other potential sources of fissile material include surplus defense plutonium $(\mathrm{Pu})$ or highly enriched uranium. A deployment model for the LWR reprocessing facility is included in the overall model. Reprocessing capacity is brought on-line as needed to sustain the growth of ALMRs. The growth rate of LWR spent fuel reprocessing capacity is restricted by the availability of spent fuel as well as by the demand for ALMR fuel. The deployment of these plants is also constrained by the economic need to have full capacity operation over the life of the facility.

The recovered actinides are sent to the fabrication end of an ALMR fuel recycle facility for fabrication into ALMR fuel assemblies. The reprocessing wastes are sent to the high level waste repository for permanent disposal and the uranium recovered from the LWR spent fuel is sent to storage. There is no provision in the current model for the re-enrichment of this spent fuel for use in LWRs.

ALMR fuel recycle facilities are deployed when adequate ALMR spent fuel inventories are available. Deployment is based on the availability of spent ALMR fuel, the need for fresh ALMR assemblies, and the economic desirability for nearly full capacity operation. In the model, the demand for ALMR fuel assemblies is met first by fuel from the ALMR recycle facility. Reload assemblies are provided for first and if any assemblies are left, they are used to satisfy initial core requirements for newly started plants. The current model includes a provision for the use of defense $\mathrm{Pu}$ up to a 


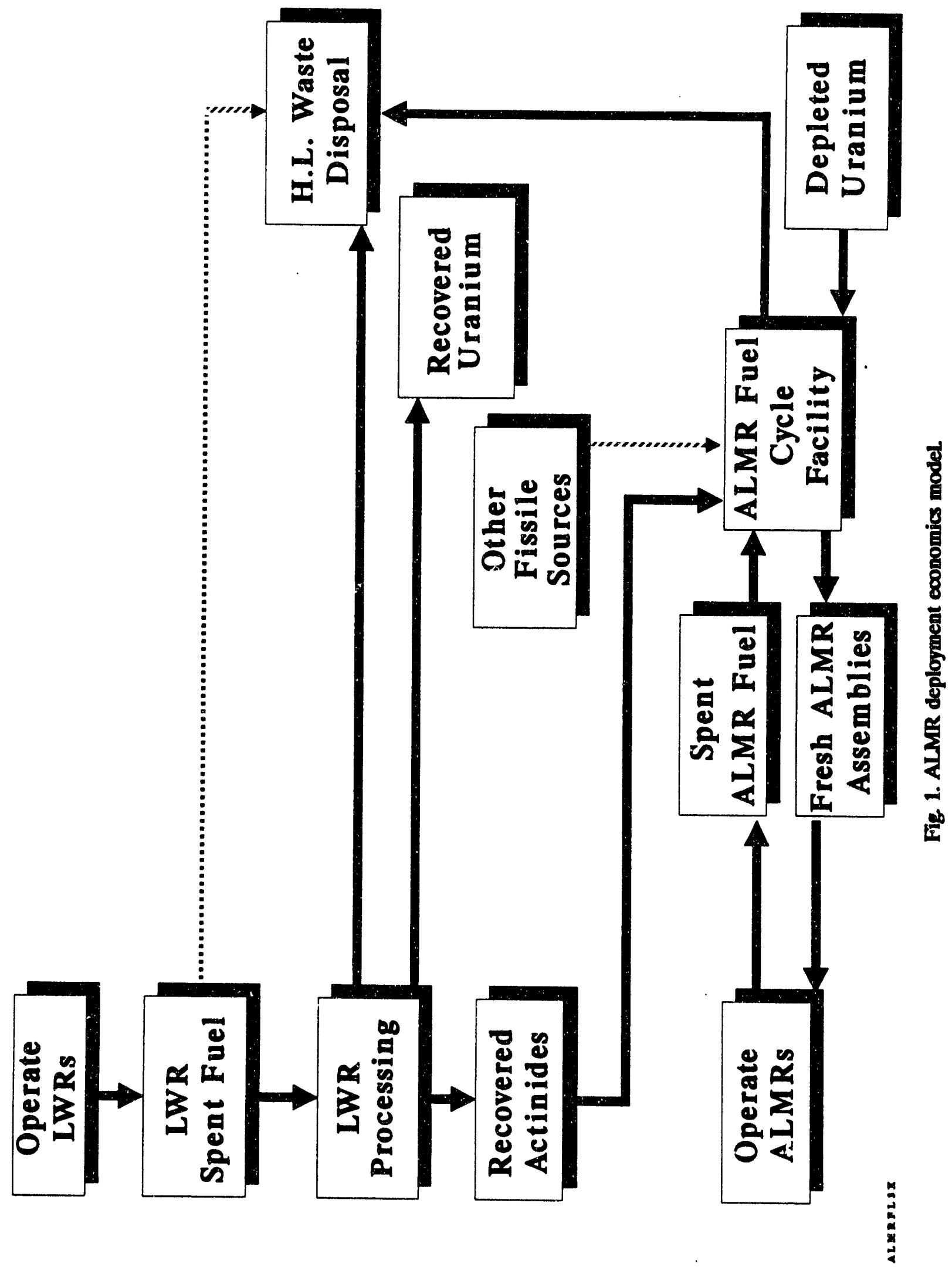


maximum amount assumed available. If the use of defense $\mathrm{Pu}$ is included, it is used to satisfy demand for fuel assemblies after the supply from the recycle facility is exhausted. The LWR reprocessing plant is the highest cost source in the current model and is the source of last resort for ALMR fuel. Waste from the ALMR fuel recycle facility is sent to the high level waste repository. In the current model depleted uranium is used as the source of any makeup uranium needed for the fuel assemblies. Although not currently reflected in the model, recovered uranium from the LWR reprocessing plant could be used as an alternative uranium source.

A pictorial view of the ALMR economics model is shown in Fig. 2. A utility revenue requirements approach is used to calculate the year-by-year costs for the ALMR plants. Each plant coming on-line produces a future stream of cost associated with capital investment, operation and maintenance $(O \& M)$, final decommissioning of the plant, and for fuel. The basic revenue requirements method is discussed in the Nuclear Energy Cost Data Base ${ }^{1}$ (NECDB). ALMR fuel cycle costs are based on the cost of the fuel assemblies purchased by the operating utilities. This assembly cost is capitalized and depreciated for tax purposes over the 5-year tax life currently allowed for nuclear fuel. The initial core fuel is depreciated for book purposes over a 30 year period whereas reload fuel is depreciated for book purposes over a fuel life of 5-years.

The fuel cycle facility (ALMR fuel recycle) plant is assumed to be industrially owned in the base set of calculations. The initial investment in this plant and its annual costs are modeled explicitly and a levelized cost of product (ALMR fuel assemblies) is calculated using an assumed 30-year plant life. The cost information for this plant was obtained from ALMR program information. ${ }^{2}$ The cost structure for an LWR spent fuel reprocessing plant was not modeled explicitly. Instead, an input reprocessing cost in terms of $\$ / \mathrm{kg}$ of heavy metal $(\$ / \mathrm{kgHM})$ was used. Defense program plutonium was assumed to be provided at a zero net cost to the ALMR. The cost of fuel assembly hardware was added to the cost of recovery to obtain the overall fuel assembly costs. Costs were estimated for the ALMR economy as a whole, and the cost of any specific reactor is not broken out separately in the model.

The LWK fuel cycle cost was estimated based on a revenue requirements calculation and 30-year mass flow requirements for an advanced LWR. The 30-year levelized unit fuel cost (mills/kWh) as a function of each fuel commodity price (i.e., uranium, conversion, enrichment and fabrication) was calculated. This sensitivity of levelized cost to commodity price was then used together with the annual power generation and the unit price of the commodity each year to obtain year-by-year fuel costs for the LWR. The capital, O\&M, and decommissioning costs for the LWR plants operating in the same time frarne as the ALMR plants were not modeled explicitly. Instead it was assumed that these costs will be the same for the two types of reactors.

The first repository and MRS system is assumed to be installed prior to the start-up of the first ALMR. The implementation and cost of subsequent repositories, and repository operating costs are estimated based on the quantity and type of high level waste disposal. These annual costs are considered to be part of the overall fuel cycle and are added to the annual costs from the ALMR and LWR fuel cycles after removal of the $1-\mathrm{mill} / \mathrm{kWh}$ waste disposal fee. The model calculates the total fuel/waste cost explicitly and independently of the assumed waste disposal fee. The reported costs are therefore net of the waste disposal fee.

The year-by-year costs are combined into Net Present Values (NPV), and these are levelized over the amount of ALMR or total nuclear energy produced in the same time period. Comparisons of these NPVs and levelized costs between any two scenarios gives the net savings or cost of implementing a specific strategy. 


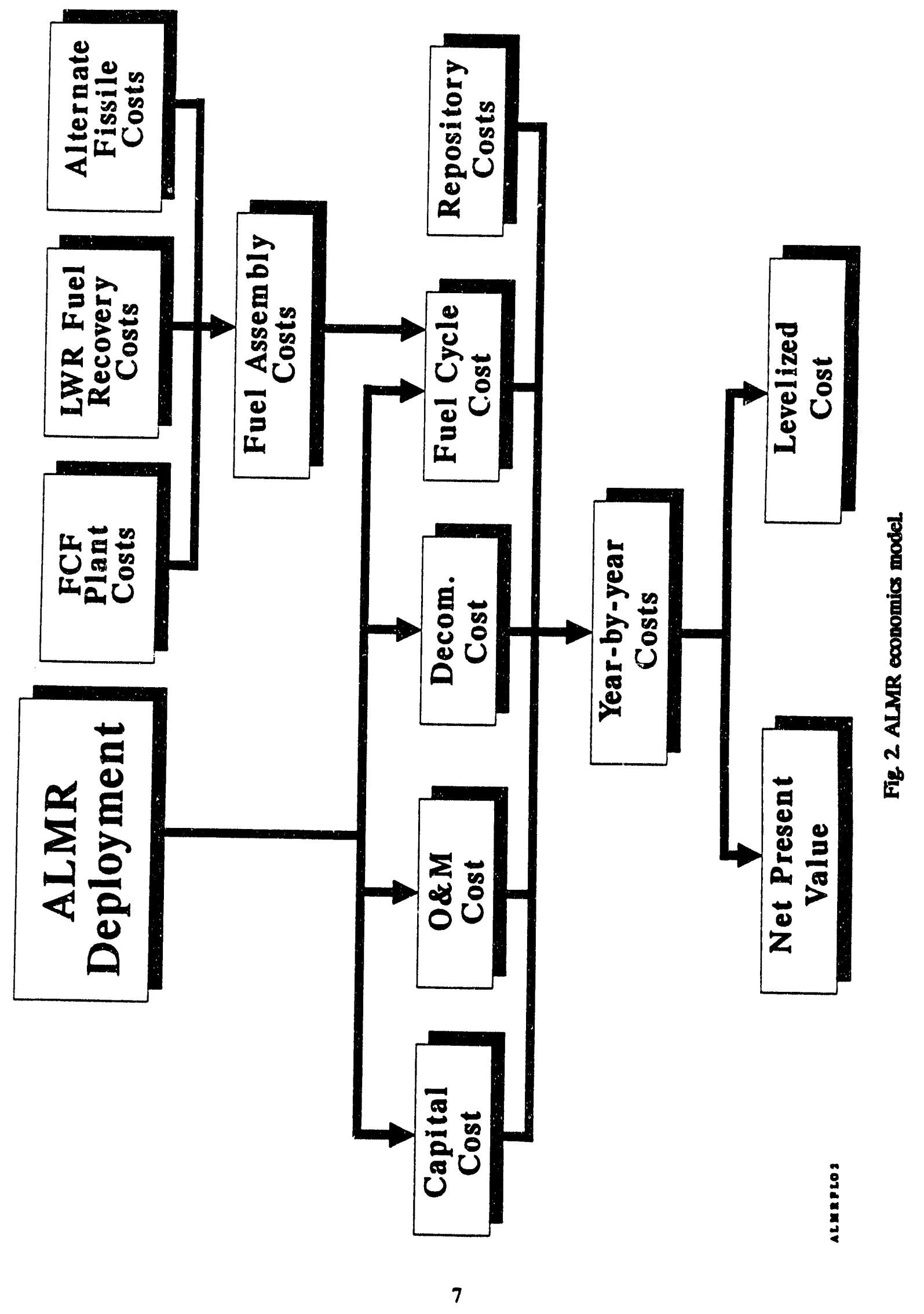




\subsection{BASIC INPUT DATA}

The basic input data to the Lotus 123 spreadsheet for the ALMR base case are shown in Tables 1-7. Items marked with an asterisk (") are input parameters. Unmarked items are calculated internally in the spreadsheet. In addition to the data shown in Tables 1-7, the year-by-year ALMR power plant deployment and LWR reprocessing plant deployment must be input. The various deployment schedules are inter-related and are dependent on the fuel cycle mass flow characteristics for each case.

In Table 1, the reactor power, base capacity factor, and decommissioning cost were obtained from General Electric ${ }^{3}$ (GE) for their Mod A reactor design. A January 1992 date was the reference date for cost information. The book depreciation life, decommissioning sinking fund rate, inflation rat:, property tax rate, and plant capital interim replacement cost fraction (fraction of initial inflated plant capital cost) assumptions were obtained from DOE's Nuclear Energy Cost Data Base (NECDB) Report. ${ }^{1}$ The year-by-year total nuclear power generation was obtained from the National Energy Strategy (NES) at 5.year increments from 2010 to 2030 with linear interpolation for the intervening years. ${ }^{4}$ The rate of increase in nuclear power generation during the 2025-2030 period $(39,400 \mathrm{GWh} /$ year) was maintained after 2030.

Table 2 contains information on ALMR plant capital and O\&M costs and on basic cost of money assumptions. The capital and operating costs were obtained from General Electric ${ }^{1}$ for a first commercial plant and an Nth-of-a-kind plant. Not all of the capital investment is deductible for tax purposes. The tax deduction fraction is that calculated by the ORNL cost review team for the ALMR plant during a 1992 cost estimate review of the ALMR. ${ }^{5}$ The learning factors (cost reduction fraction for a doubling in number of plants) shown were computed from the first-of-a-kind (FOAK) and Nthof-a-kind (NOAK) cost assuming two doublings from FOAK to NOAK plant (i.e., fourth plant is assumed to be the NOAK plant). The capitalization fractions and returns on each type of capital for both utility and industrial operation are input. These values were obtained from the NECDB. ${ }^{1}$ The industrial financing assumptions were used for the fuel cycle facilities.

ALMR fuel cycle data is shown on Table 3 for the base (burner) fuel cycle. Fuel cycle information for alternate fuel assumptions is discussed later in this report. The fuel cycle time, driver fuel assembly equivalent charge and discharge fissile material content, assembly heavy metal loading and the number of core and blanket assemblies for the initial core and each reload were provided by $\mathrm{GE}^{3}$ Where applicable, the equivalent fissile $\mathrm{Pu}$ discharge value includes $\mathrm{Pu}$ discharged in the blanket assemblies prorated to the driver assemblies. In the base case, there was assumed to be no alternative fissile material (e.g., weapons $\mathrm{Pu}$ ) available. The fissile $\mathrm{Pu}$ in $\mathrm{LWR}$ spent fuel varies depending on fuel characteristics, spent fuel burnup, and time since discharge. The value shown is typical and will vary approximately in the range of 6 to $7 \mathrm{~kg} / \mathrm{MTHM}$.

The LWR actinide recovery (reprocessing) plant was sized to meet the fuel cycle needs while continuing to operate at full capacity. The $\$ 350 / \mathrm{kgHM}$ LWR spent fuel reprocessing cost is a program assumption based on preliminary estimates by ANL. The initial core fuel loadings were depreciated for book purposes over the same period as the reactor plant (30 years). A 5-year book depreciation was assumed for the reload fuel. In all cases the fuel was depreciated for tax purposes over the 5-year tax depreciation schedule allowed for nuclear fuel. Any weapons Pu used in the analyses was assumed to be obtained at zero net cost. 
Table 1. General Information

ALMR Deployment Model

Date : 01-27-93

Costs (1992 \$) and rates:

Cost.................

Reactor Power *

Capacity Factor *

Income Tax Rate *

Reference Year *

Book Depr. Life *

Decommissioning cost *

Decomm. Sinking fund rate *

Annual Decommissioning cost

Inflation factor *

Equity Return

Avg. Cost of Money

After tax COM

Pres. Worth Factor

Const $\$$ COM

Const $\$$ P. Worth Fact

Property Tax Rate *

Interim Replacement Rate *

Post-2030 Nucl. Generation

Annual Power Production

NPV of Power, Noml \$/Const \$

30 years (GWh)

Book Life (GWh)

2010-2050 (10^3 GWh)

2010-2060 (10^3 GWh)

2010-2070 (10^3 GWh)
Base Case Burner

Case: ALMRAO01

GWe

1.488

0.86

0.3664

end of year 1991

Years 30

\$M 508

0.070

13.7

1.050

0.0650

0.1135

0.0957

1.0957

0.04355

1.0436

0.02

0.0050

39.4

11210

109559185750

109559185750

1176.73703 .3

$1298.4 \quad 4856.8$

1354.95728 .0

* = Input parameters 
Table 2. ALMR Cost Factors

ALMR Capital and O\&M Costs

First Commercial plant

Initial Investment, \$M * 2825.0

Tax Deduct Fraction * 0.8292

Depreciable Capital, \$M 2342.5

Annual O\&M costs, \$M/Yr* 113.3

NOAK Plants

Initial Investment, $\$ M$ * 2413.0

Tax Deduct Fraction * 0.8663

Depreciable Capital, \$M 2090.4

Annual O\&M costs, \$M/Yr* 89.6

Plant Learning Factors

Capital Cost

0.924

O\&M Costs

0.889

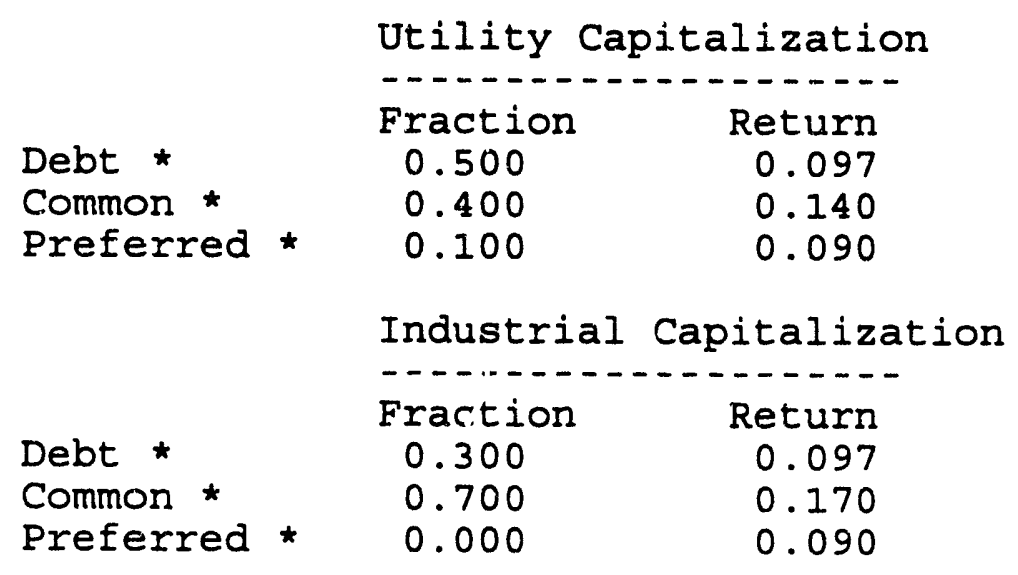

* = Input parameters 
Table 3. ALMR Fuel Cycle Parameters

ALMR Deployment Assembly needs MOD A - 0.69 conversion ratio Fuel Cycle Data

Fissile Material Balance Status

Fuel Cycle Time *

Equivalent Fissile Pu/Driver Assy , kg Charged * Discharged *

Recycle assemblies fabricated/discharged

Pu-239 Available from weapons, MT * OK

Fissile $\mathrm{Pu}$ in LWR Spent Fuel, kg/MTHM *

Assembly Heavy Metal, kg/assembly * Driver Blanket

Core/Blanket Assemblies (full plant) * Initial core Reload

Blanket/driver assembly ratios Initial core Reload/discharge OK 15

6.53

6.12

0.9372

0.0

6.35

69.4

0.0

1242.0

0.0

414.0

0.0

Driver Assemblies per MTHM Throughput

0.000

0.000

LWR Actinide Rec Plant Size *

LWR Fuel Reprocessing cost *

MTHM/Yr 2000

$\$ / \mathrm{KgHM} \quad 350$

Fuel Book Depr. Life *

Years

Initial Fuel

Recycle fuel

Initial fuel tax deduct fraction

LWR-Actinide Recovery cost

Weapons Pu Assembly cost *

\begin{tabular}{|c|c|}
\hline & $\begin{array}{r}30.000 \\
5.000 \\
0.9416\end{array}$ \\
\hline $\begin{array}{l}\text { M/Ass } \\
M / A s s\end{array}$ & $\begin{array}{l}0.3599 \\
0.0000\end{array}$ \\
\hline
\end{tabular}

* = Input parameters 
The input data given in Table 4 was mainly derived from the ALMR 1991 Fuel Cycle Cost Report ${ }^{2}$ as modified in the DOE review. ${ }^{5}$ A facility life of 30 years is assumed. The $2 \%$ property tax rate is the same as for the reactor plants. The base size for the recycle facility is 200 MTHM/year although various sizes were used in the analysis in order to maintain adequate flows of material.

The costs shown are for a FOAK plant. Unit learning curves were used to move from the FOAK to NOAK costs. NOAK cost factors were given in Ref. 2 and modified in the subsequent review.' Using the factors applicable to capital cost, the total reduction for a fourth-of-a-kind plant was computed. Plant costs were fixed at this level (a total reduction of $0.911^{2}$ ) for all subsequent plants. The second and third plant were assumed to have a cost equal to 0.911 of the FOAK cost. The manpower and consumables costs were based on the cumulative driver assemblies recycled. The base amount for learning was the total number of assemblies required for 30-years of operation for a single full size plant from Ref. 2. The hardware cost is based on the cumulative driver assemblies fabricated. The learning factor applied over the number of cumulative quantity doublings shown gives the NOAK cost. This cumulative learning is approximately equal to the total learning between FOAK and NOAK plants from Ref. 5.

Table 5 shows the high level waste repository assumptions. There are many aspects of the repository and its costs which are uncertain and extrapolations had to be made from existing information in several instances. Basic technical and year-by-year cost information for several scenarios can be found in 2 DOE report.' This report, however, does not include any information on reprocessing waste disposal or the scenarios considered herein. The current repository capacity planned is 70,000 MTHM with 7,000 devoted to defense wastes, hence the assumed capacity of 63,000 MTHM. The model provides for either the disposal of intact LWR fuel assemblies or the reprocessing wastes therefrom. The current assumed spent fuel disposal rate ${ }^{7}$ is $3,000 \mathrm{MTHM} / \mathrm{year}$. The analysis assumes this rate for the first repository, however, this rate will not be adequate to dispose of all spent fuel in an expanding nuclear economy, so it was assumed that provision will be made to increase this maximum rate (doubled) for subsequent repositories. Spent fuel was assumed available for disposal or reprocessing 2-years after discharge from the reactor. At this point it entered an inventory available for disposal. Actual disposal follows availability by several years depending on the inventory magnitude.

The first repository is assumed to be in place by the initial year of this analysis (2010) and is the same for all scenarios considered in this study. With respect to this study, it is a sunk cost with an assumed zero incremental cost. The cost for subsequent repositories was derived from cost information for a second repository in Ref. 7, escalated to 1992 dollars. It is the total cost of all site characterization, licensing, construction, etc. paid toward putting a second repository in place.

Operating costs can be divided into fixed costs which are independent of the waste throughput and a variable component which is proportional to the waste disposal rate. The numbers shown are approximate values for the disposal of intact spent fuel and are based on this study's analysis of the reported cost estimates. The fixed cost is a per repository cost and is applied even if a repository is full.

Since more reprocessing wastes than assembly wastes (based on the heavy metal in the initial fuel) can be placed in a single can, a cost reduction per unit of initial fuel can be expected. The magnitude of this savings is not well defined but could be significant. Estimates range from a $20-30 \%$ savings to as $\mathrm{hi}^{\prime} \mathrm{h}$ as $75 \%$. The latter is based on the amount of material that can be put in a single package and dives not include consideration of concomitant costs such as increased costs of handling, additional expenditures for additional ventilation shafts, ventilation equipment, and power to run the equipment. A cost factor (multiplier to variable cost of disposing of fuel assemblies) range of 0.5 to 
Table 4. ALMR Fuel Cycle Facility Parameters

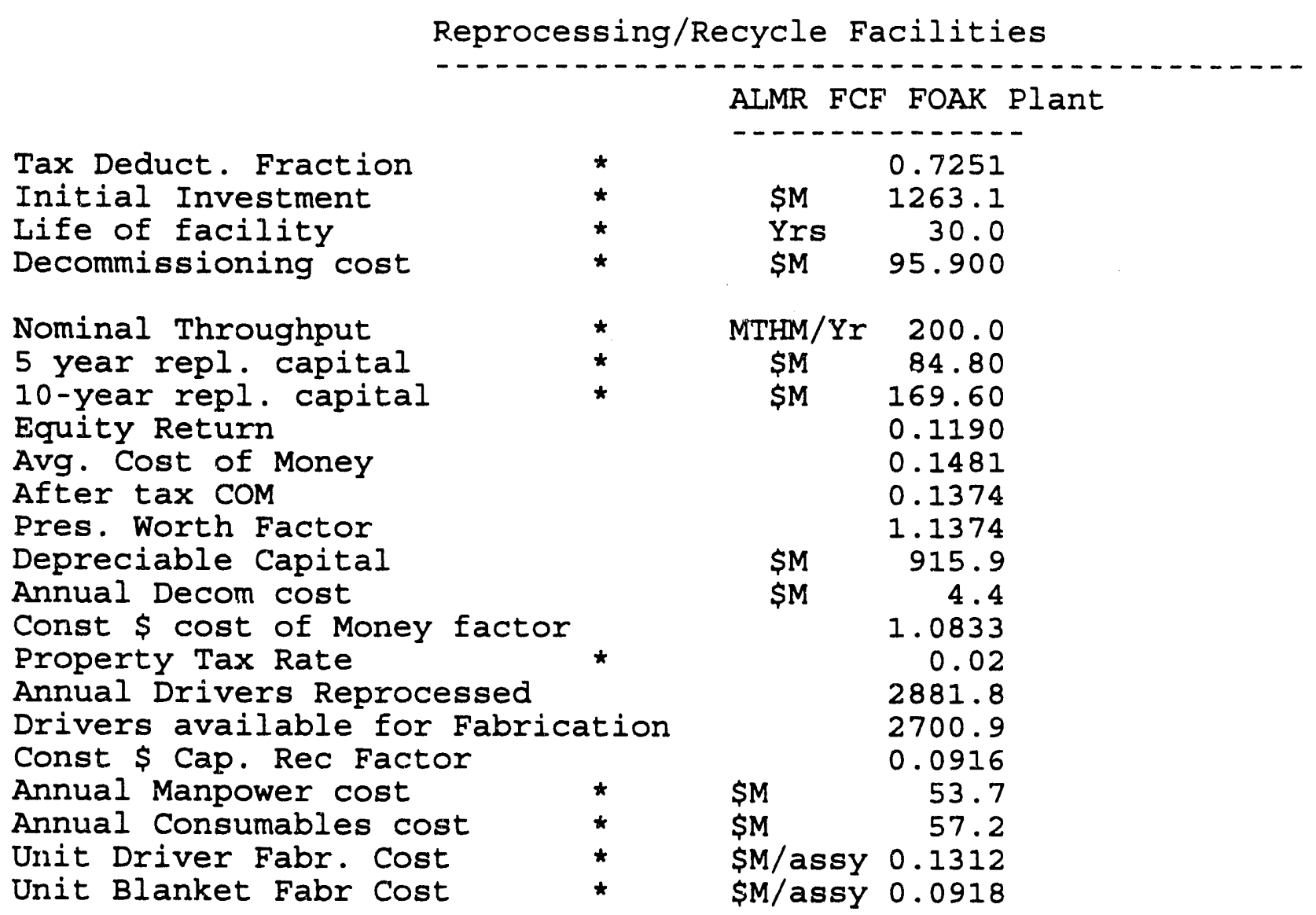

Maximum

$\begin{array}{llrrr} & \text { Basis } & \text { Base* } & \text { Factor*Doublings* } \\ \text { Unit learning } & & & \\ \text { FCF capital cost } & \text { Full plants deployed } & 1.0 & 0.911 & 2.0 \\ \text { Manpower } & \text { Cuml Recycle Drivers } & 3276.0 & 0.900 & 3.0 \\ \text { Consumables costs Cuml Recycle Drivers } & 3276.0 & 0.940 & 3.0 \\ \text { Hardware costs } & \text { Cuml. Driver Assem } & 3276.0 & 0.900 & 4.0\end{array}$

* = Input parameters 
Table 5. Repository Model Parameters

Repository Model Parameters

Repository LWR Assem. Capacity* Type of Disposal Indicator*

$0=$ LWR Fuel Ass., 1 = Repro waste

Max. Rate of Assembly Disposal First Repository* Subsequent Repositories* First Repository Capital Cost* Additional Repository Capital Cost* Annual Fixed Cost per Repository* Unit cost of Assembly Disposal* Cost factor for REPRO waste disposal* Unit Cost of Repro Waste Disp. Disposal Availability Lag Time* Repro waste equiv factor*

Avg. LWR fuel Burnup 1992-2010*

Waste Fee Escalation Factor*

H. L. Waste Fee*

Spent Fuel MRS Capacity Charge*

Threshold for next repository*

Cumul. LWR HM @ 2009* MT-HN

MTHM

63000

Cuml ore consumption 1992-2010*

MTHM/Yr

1.0 3000.0 6000.0 $\$ M$ 0.0 $\$ M / Y r$ $\$ / \mathrm{kgHM}$ 7200.0 20.0

$\$ / \mathrm{kgHM}$ years

$\mathrm{MWd} / \mathrm{kg}$

Mills/kWh \$/kgHM MTHM

145.0

0.75 108.8 2.0 0.25 40.0 1.05 1.0 20.0 3000.0 60000

Ktons 400.0

* = Input parameters 
0.75 was considered in this study with a reference value of 0.75 . In other words, the disposal of reprocessing wastes from a given amount of spent fuel is assumed to cost $75 \%$ of the cost of disposing of the same amount of intact spent fuel.

In addition to a cost impact, there is also a potential disposal density effect as a result of reprocessing. For this study, a reprocessed waste equivalence factor has been used as a measure of the repository's ultimate capacity. The base 0.25 factor assumes that four times as much initial heavy metal can be stored in a waste repository if the spent fuel has been reprocessed. This compaction is due to reduced long-term thermal loading. This factor is consistent with Refs. 8 and 9.

The LWR spent fuel burnup is assumed to be $40 \mathrm{MWd} / \mathrm{kg}$ throughout this study. The current high level waste fee of $1 \mathrm{mill} / \mathrm{kWh}$ is used with an escalation rate equal to the assumed 5\% inflation rate. Consistent with the analysis in Ref. 7, an MRS is assumed to be in place prior to the time frame in this analysis. Examination of the repository program cost information indicates an incremental cost for added MRS storage of less than \$20/kgHM. This value was used as the reference charge if the inventory of spent fuel increased over its previous maximum value. The amount of spent fuel available and the amount of uranium used in the future will depend on various factors. The total of 60,000 MTHM spent fuel in 2010 and the 400,000 tons of $\mathrm{U}_{3} \mathrm{O}_{8}$ consumption between 1992 and 2010 are consistent with current estimates. ${ }^{10}$

Table 6 contains LWR fuel cycle parameters. The study assumed for its baseline analysis an LWR spent fuel burnup of $40 \mathrm{MWd} / \mathrm{kg}$. The projected burnup from U.S. reactors in the post 2010 period is generally in the $40-50 \mathrm{MWd} / \mathrm{kg}$ range. ${ }^{10}$ The $\mathrm{LWR}$ fuel enrichment is a function of fuel burnup and is based on an algorithm derived from information on the Westinghouse AP-600 fuel cycle and sensitivities of enrichment versus burnup for Westinghouse PWRs. Optimal enrichment plant tails enrichments are a function of the fuel enrichment and prices for uranium and separative work. The $0.25 \%$ value has been projected for the post 2010 period. $^{10}$ The plant heat rate is for a plant thermal efficiency of $33.3 \%$.

The uranium ore grade is not currently used in the model. While, this quantity is expected to decrease over time as the richer resources are used up, the value shown corresponds to a $\mathrm{U}_{3} \mathrm{O}_{8}$ content of $0.15 \%$ in the ore. The fuel cycle commodity prices shown are the estimated price in 1992 dollars in the year 2010. The prices assume a nuclear resurgence with new production coming on line. The uranium price is an estimate of the price to which uranium will have to rise before such new production will be economic in the United States. The enrichment price is the current price for a U.S. enrichment enterprise "Utility Service Contract." Conversion and fuel fabrication price are estimated prices from new facilities. As the resource is used up, the price of uranium should increase. There is a great deal of uncertainty as to what the future cost of uranium will be and on the quantity of uranium which will ultimately be available. The uranium price vs. cumulative consumption is based on the reported ${ }^{11}$ reasonably assured reserves available at various forward costs of uranium. Information was given at $\$ 30, \$ 50$ and $\$ 100 / \mathrm{b}$. $\mathrm{U}_{3} \mathrm{O}_{8}$. The $\$ 150$ point was obtained by making a linear extrapolation from the $\$ 50$ and $\$ 100$ points. The $\$ 150 / \mathrm{hb}$ value is about the minimum cost where uranium might be extracted from sea water so the price was projected to remain constant after 3.3 million tons U.S. uranium oxide consumption.

Table 7 shows parameters used in the LWR fuel cycle cost calculation. The only parameters not calculated internally in the program are the processing losses. The loss factors shown are those recommended in Ref. 1. 
Table 6. LWR Fuel Cycle Information

LWR Fuel cycle parameters

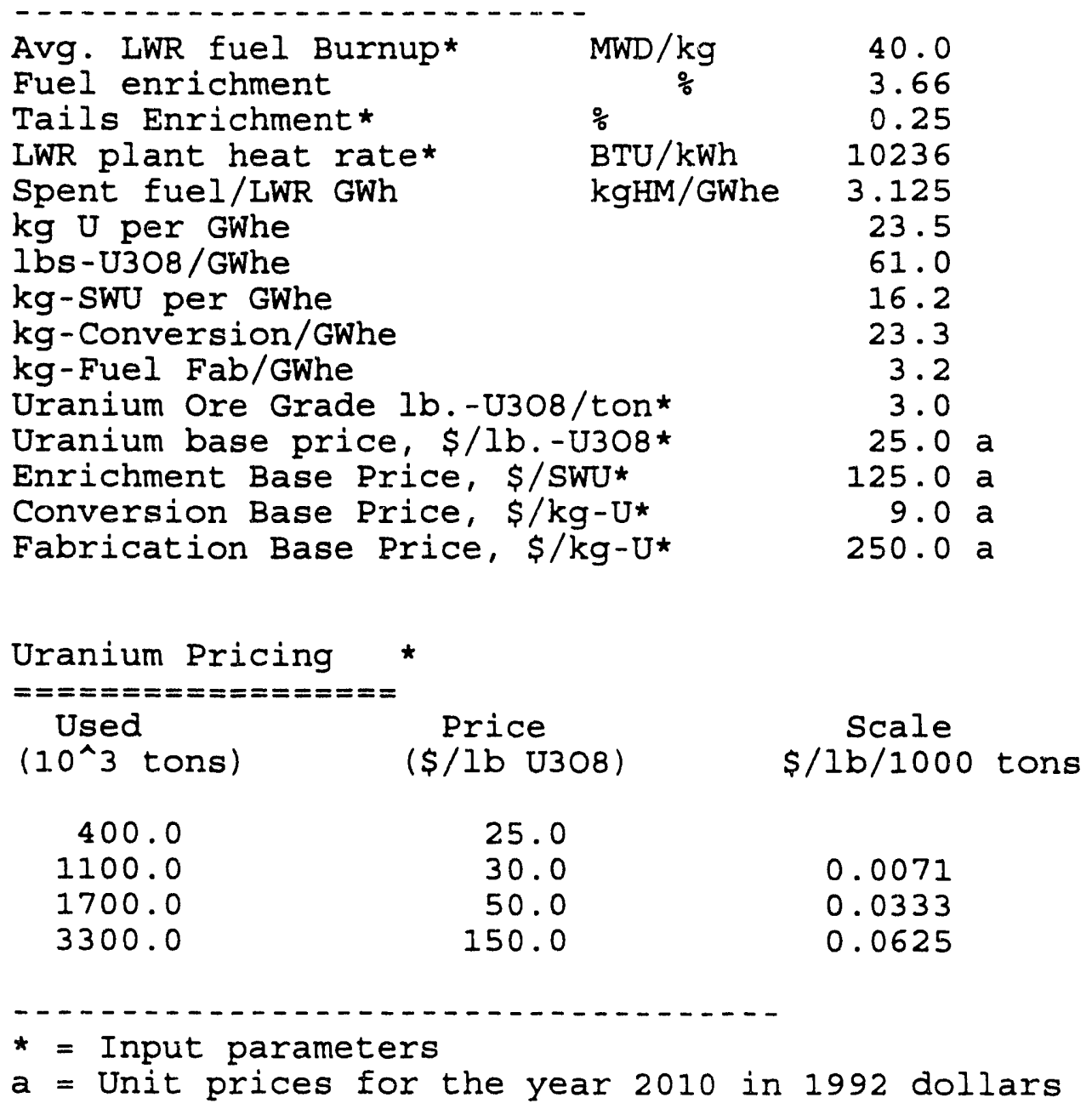


Table 7. LWR Fuel Cycle Parameters

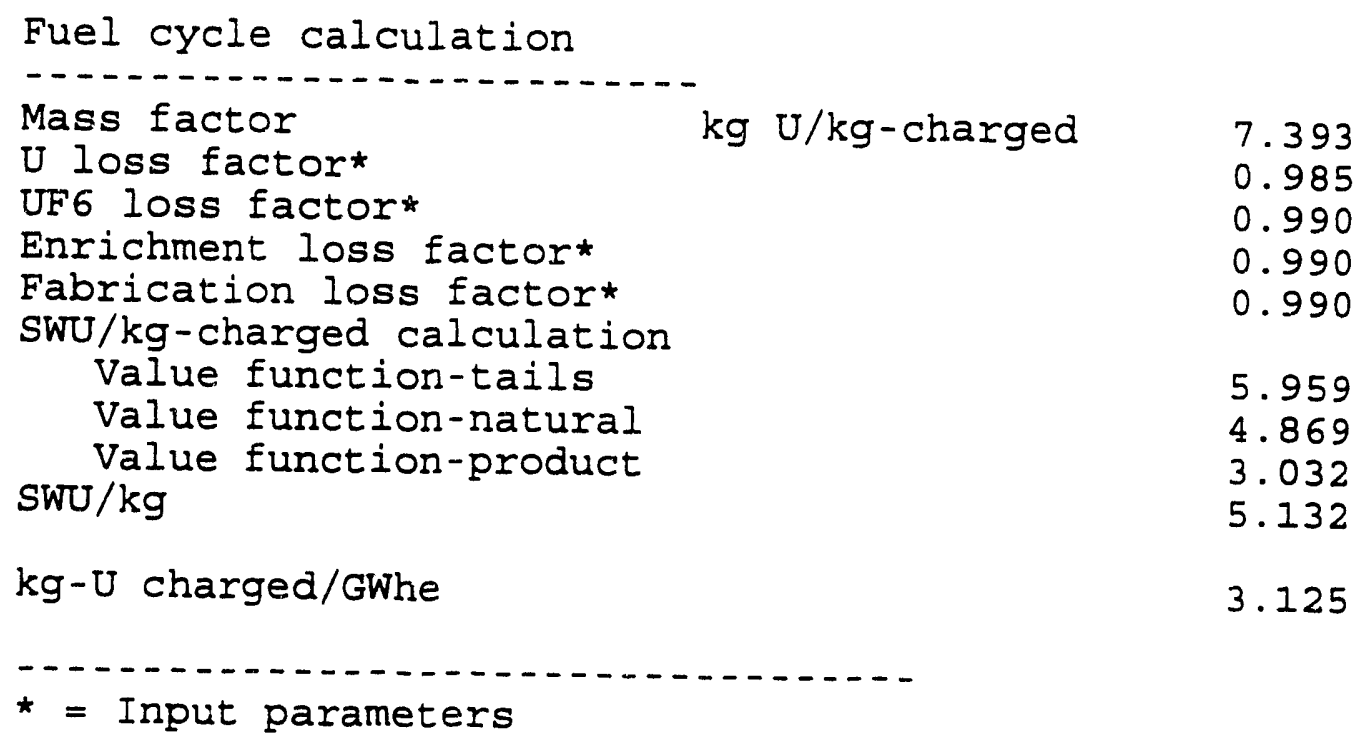




\subsection{INPUT VARIATIONS}

The basic input was discussed in the previous section. Sensitivity of the results to variations in the input data was examined. Several reactor/fuel cycles were considered as given in Table 8 . Mod A and Mlod B are two different reactor designs being considered for the ALMR. Table 9 gives the reactor power and costs for these two systems. The information in Tables 8 and 9 were obtained from $\mathrm{GE}^{3}$ Other parameters varied in the sensitivity analysis are given in Table 10. Variations in cost parameters were made around the ALMR Base Case. A list of cases run in the analysis and their spreadsheet filenames are given in Appendix A. 
Table 8. ALMR fuel cycle parameters

\begin{tabular}{|c|c|c|c|}
\hline Reactor model & Mod A & $\operatorname{Mod} A$ & Mod B \\
\hline Fuel cycle type & Burner & Breakeven & Breeder \\
\hline Conversion/breeding ratio & 0.69 & 1.05 & 1.24 \\
\hline Fuel cycle time, months & 15 & 24 & 23 \\
\hline $\begin{array}{l}\text { Equiv. fissile Pu/driver, } \mathrm{kg} \\
\text { charged } \\
\text { dischirged }\end{array}$ & $\begin{array}{l}6.53 \\
6.12\end{array}$ & $\begin{array}{l}21.9 \\
22.1\end{array}$ & $\begin{array}{l}14.52 \\
17.30\end{array}$ \\
\hline $\begin{array}{l}\text { Assembly heavy metal, kg } \\
\text { driver } \\
\text { blanket }\end{array}$ & $\begin{array}{l}69.4 \\
\text { NA }\end{array}$ & $\begin{array}{l}88.0 \\
151.0\end{array}$ & $\begin{array}{l}120.03 \\
166.13\end{array}$ \\
\hline $\begin{array}{l}\text { Full plant driver assemblies } \\
\text { initial core } \\
\text { reloads }\end{array}$ & $\begin{array}{l}1242 \\
414\end{array}$ & $\begin{array}{l}594 \\
198\end{array}$ & $\begin{array}{l}756 \\
252\end{array}$ \\
\hline $\begin{array}{l}\text { Plant blanket assemblies } \\
\text { initial core } \\
\text { reloads }\end{array}$ & $\begin{array}{l}0 \\
0\end{array}$ & $\begin{array}{l}648 \\
162\end{array}$ & $\begin{array}{l}648 \\
180\end{array}$ \\
\hline
\end{tabular}


Table 9. ALMR plant cost variations (million 1992 dollars)

\begin{tabular}{|c|c|c|}
\hline Plant type & Mods & $\operatorname{Mod} B$ \\
\hline Reactor power, MWe & 1488 & 1818 \\
\hline Decommissioning cost & 508 & 524 \\
\hline $\begin{array}{l}\text { First commercial plant } \\
\text { initial investment } \\
\text { annual O\&M cost }\end{array}$ & $\begin{array}{l}2825 \\
113.3\end{array}$ & $\begin{array}{l}2992 \\
119.8\end{array}$ \\
\hline $\begin{array}{l}\text { NOAK plant } \\
\text { initial investment } \\
\text { annual O\&M }\end{array}$ & $\begin{array}{l}2413 \\
89.6\end{array}$ & $\begin{array}{l}2556 \\
94.9\end{array}$ \\
\hline
\end{tabular}


Table 10. Additional parameters varied

\begin{tabular}{lcl}
\hline \multicolumn{1}{c}{ Item } & $\begin{array}{c}\text { Base } \\
\text { Parameters }\end{array}$ & Parameter Variations \\
\hline Deploy ALMRs & Yes & No (null case) \\
Nominal capacity factor & 0.86 & $0.80,0.75$ \\
ALMR power in 2030, Gwe & 27 & Max achievable \\
Conversion/breeding ratio & 0.69 & $1.04,1.25$ \\
$\begin{array}{l}\text { Pu available from weapons, MT } \\
\text { LWR fuel recovery cost, S/kgHM }\end{array}$ & 0 & 100 \\
$\begin{array}{l}\text { Cost to implement repository, SB } \\
\text { LWR processing waste } \\
\text { repository load factor } \\
\text { repository cost factor }\end{array}$ & 350 & 200,1000 \\
$\begin{array}{l}\text { LWR fuel processing costs } \\
\text { charged to repository }\end{array}$ & 7.2 & 15 \\
\hline
\end{tabular}

Parameters varied one at a time from base parameter set. 


\section{CASE RESULTS}

As described in Sect. 1.3, several different scenarios have been modeled. The selection of cases in this report is by no means exhaustive. They do show, however, the degree of economic sensitivity to changes in various input assumptions. In each ALMR case, the relative economic advantage as compared to a null (no ALMR) case was determined.

\section{NO ALMR CAŃE (NULL CASE)}

This case servi $=$ a relative benchmark for all ALMR cases. In this case, it is assumed that all nuclear generation is provided by LWR plants and that unreprocessed spent fuel is buried in the repositories. The LWR fuel cycle costs were developed on the basis of the data provided in Tables 6 and 7. The assumed annual energy generation in terawatt-hours (TWhe) is shown in Fig. 3. Due to the growing amount of nuclear generation, demand for uranium ore increases as shown in Fig. 4. This results in an assumed increased price for ore as also shown in Fig. 4.

One of the most significant impacts of this case is the amount of spent fuel (heavy metal) that will have to be piasieu in repositories. As shown in Fig. 5, the limit of the first repository is reached in 2029, with new repositories needed approximately every 10 years. During the 60 year period shown in Fig. 5, five repositories would be needed at the current loading limit.

The cost summaries for this case are shown in Table 11. The ALMR cases that fol ; w will compare their costis to those presented in this table.

\subsection{BASF: ALMR BURNER}

For purposes of relative comparison, a set of ALMR data was selected to be the base case. The specific data for this case are described in Sect. 1.2. The annual energy generation assumed for this case is shown in Fig. 6. The uranium ore use and price for LWR plants are presented in Fig. 7. As a result of the deployment of ALMRs, the demand for uranium is less than in the no ALMR case depicted in Fig. 4.

One of the most striking features of this case, and for all ALMR cases, is the reduction in the rate in which waste repositories are filled. Owing to the removal of spent fuel actinides via reprocessing, and the, resulting decrease in long-term thermal heai loading, more spent fuel material (i.e., fission products) can be volumetrically accommodated in the repositories. This leads to a thermal heavy metal equivalence which, in effeci. Iills the repositories at a much slower rate. With the base case 0.25 waste equivalency $f=\cdots$. cour times as much initial heavy metal in the form of reprocessing wastes can be accommodated in a repository as compared to intact spent fuel assemblies. Therefore, one metric ton of equivalent heavy metal corresprads to four MTHM in an unprocessed (intact) state. A.s shown in Fig. 8, after reprocessing LWR spent fuel, the equivalent heavy metal disposed in the refositories is such as to not require a second repository (at the current loading limit of 63,000 MTHM) until 2061, 5i years after the start of the first repository.

The resulting costs for this case are shown in Table 12. The differential costs, comparing this case to the no ALMR case, are provided in Table 13. As shown, the higher cost of uranium and waste repos: tories in the nn ALMR case are initially offset by the cost of the ALMR fuel cycle. In 


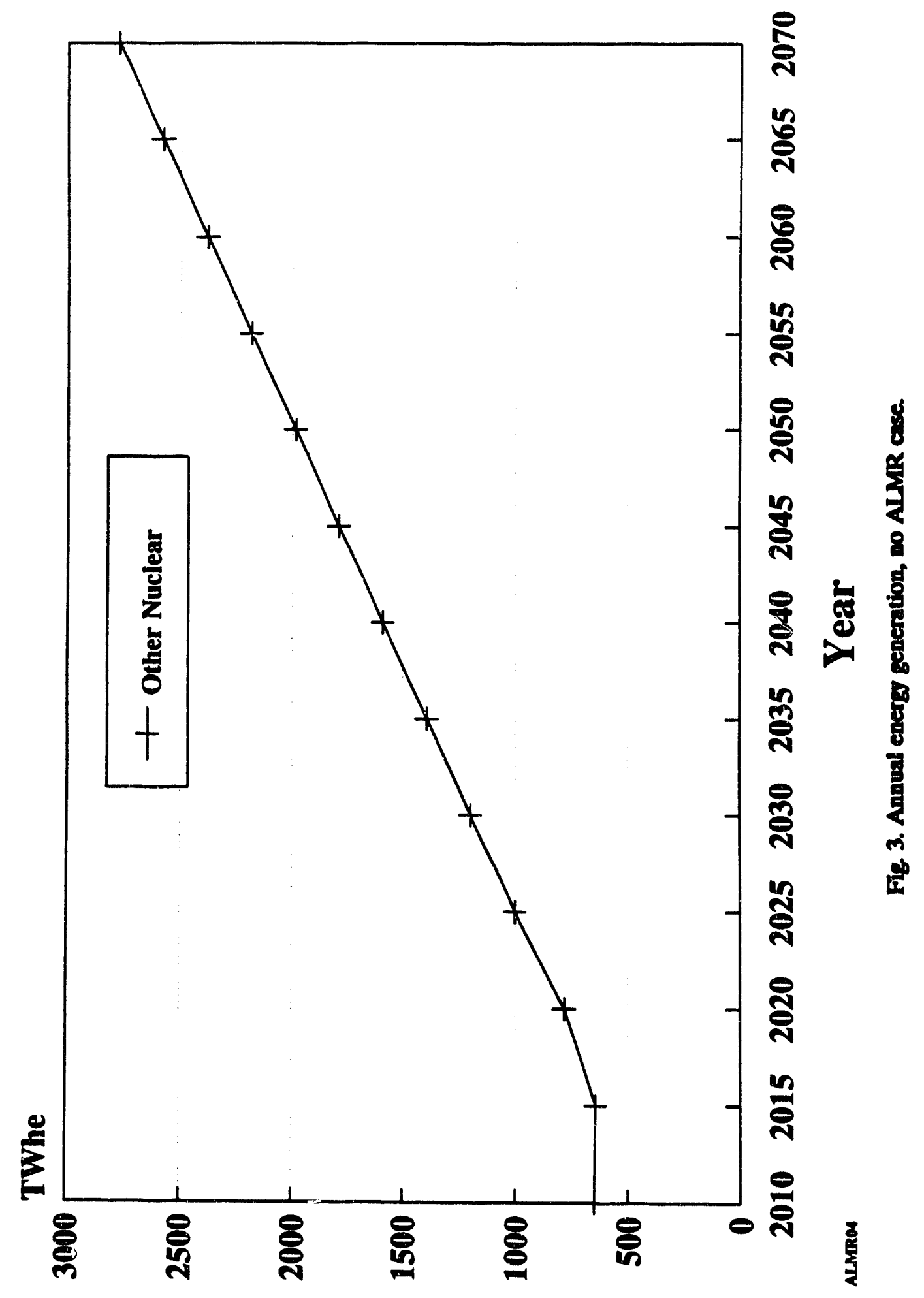




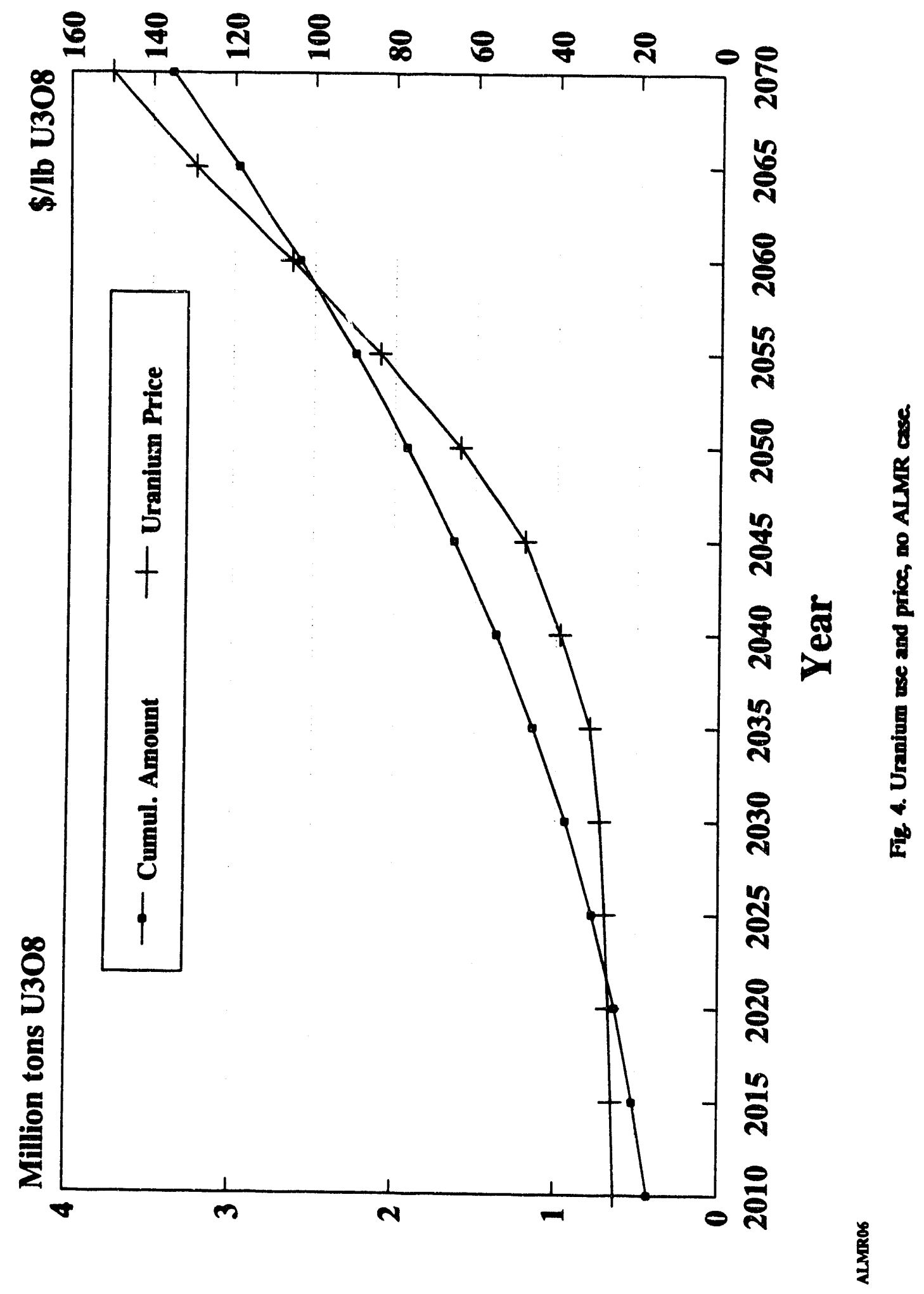




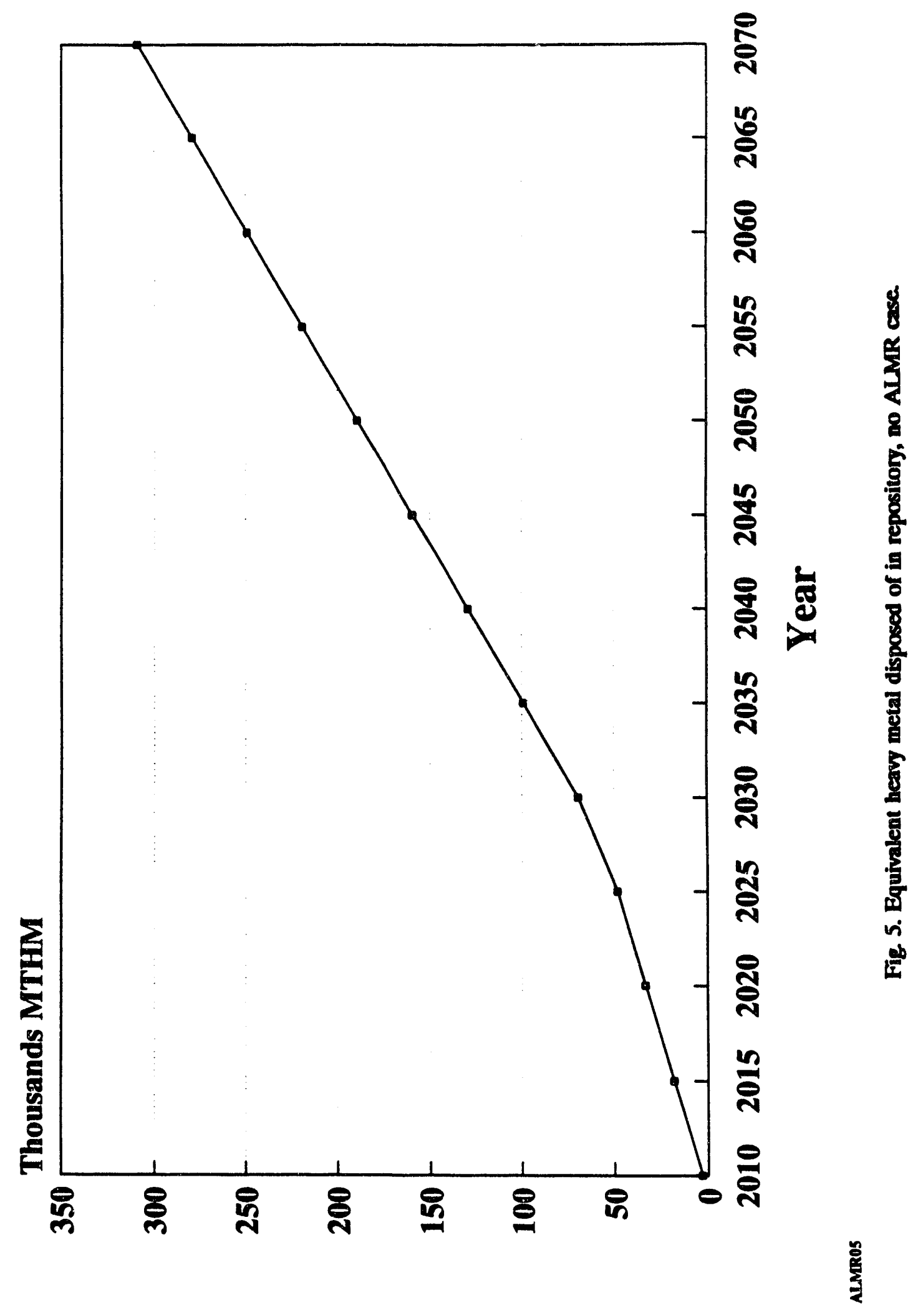


Table 11

\begin{abstract}
ALMR Deployment Model
Nul Case with no ALMR Deployment

Revised 01-26-93

Case: ALMR0000
\end{abstract}

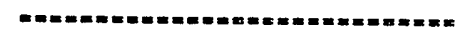

Present worth at utility COM, Ref. year \$

2010 to:

ALMR Power

IWR Power

Total Nuclear Power

$\begin{array}{lrrrrr} & 2030 & 2040 & 2050 & 2060 & 2070 \\ & \ldots \ldots & \ldots \ldots & \ldots \ldots & \ldots \ldots & \ldots \ldots \\ \text { TWh } & 0 & 0 & 0 & 0 & 0 \\ \text { TWh } & 10803 & 15357 & 19168 & 22203 & 24541 \\ & 10803 & 15357 & 19168 & 22203 & 24541\end{array}$

Present worth

Nuclear Fuel Cost

2010 to:

$\begin{array}{lllll}2030 & 2040 \quad 2050 \quad 2060 \quad 2070\end{array}$

ALMR Fuel Cycle

LWR Fuel Cycle

H.L. Waste Repos

less Waste Fee Revenue

Net Fuel Cost NPV

\begin{tabular}{lrrrrr}
\multicolumn{8}{c}{2010 to: } & & & \\
& 2030 & 2040 & 2050 & 2060 & 2070 \\
MS & 0 & 0 & 0 & 0 & 0 \\
MS & 88357 & 128170 & 167622 & 209176 & 251175 \\
MS & 9629 & 14606 & 17840 & 19980 & 20859 \\
MS & 10803 & 15357 & 19168 & 22203 & 24541 \\
& $\ldots \ldots \ldots$ & $\ldots \ldots$ & $\ldots \ldots$
\end{tabular}

MS

87183127420166294205954247492

AIMR Levelized Plant Costs, mills/kWh Capital

OCM

Decommissioning

Fuel (incl. waste fee)

Total Levelized AIMR Plant Cost

\begin{tabular}{|c|c|c|c|c|}
\hline 2030 & 2040 & 2050 & 2060 & 2070 \\
\hline$\ldots$ & $\cdots$ & $\cdots$ & -.... & $\cdots$ \\
\hline 0.0 & 0.0 & 0.0 & 0.0 & 0.0 \\
\hline 0.0 & 0.0 & 0.0 & 0.0 & 0.0 \\
\hline 0.0 & 0.0 & 0.0 & 0.0 & 0.0 \\
\hline 0.0 & 0.0 & 0.0 & 0.0 & 0.0 \\
\hline 0.0 & 0.0 & 0.0 & 0.0 & 0.0 \\
\hline
\end{tabular}

Fuel cost levelized over

all nuclear generation, mills/kwh

$$
\text { Fuel }
$$

less waste fee

Net fuel cost

H. L. waste repository

Total Levelized Fuel Cost

\begin{tabular}{|c|c|c|c|c|c|c|}
\hline & $\cdots$ & $\cdots$ & $\cdots$ & $\cdots$ & $\cdots$ & \\
\hline & 8.18 & 8.35 & 8.75 & 9.42 & 10.23 & \\
\hline & 1.00 & 1.00 & 1.00 & 1.00 & 1.00 & \\
\hline & 7.18 & 7.35 & 7.75 & 8.42 & 9.23 & \\
\hline & 0.89 & 0.95 & 0.93 & 0.90 & 0.85 & \\
\hline & $\cdots$ & $\cdots$ & -- & $\cdots$ & - & \\
\hline & 8.07 & 8.30 & 8.68 & 9.32 & 10.08 & \\
\hline Year Start & $2010-$ & $2021-$ & 2031- & $2041-$ & 2051- & 2061- \\
\hline Year End & 2020 & 2030 & 2040 & 2050 & 2060 & 2070 \\
\hline & $\cdots$ & $\cdots$ & $\cdots$ & $\ldots \ldots$ & $=-$ & - \\
\hline ills/kwh & 7.77 & 8.12 & 8.84 & 10.20 & 13.40 & 7.33 \\
\hline
\end{tabular}




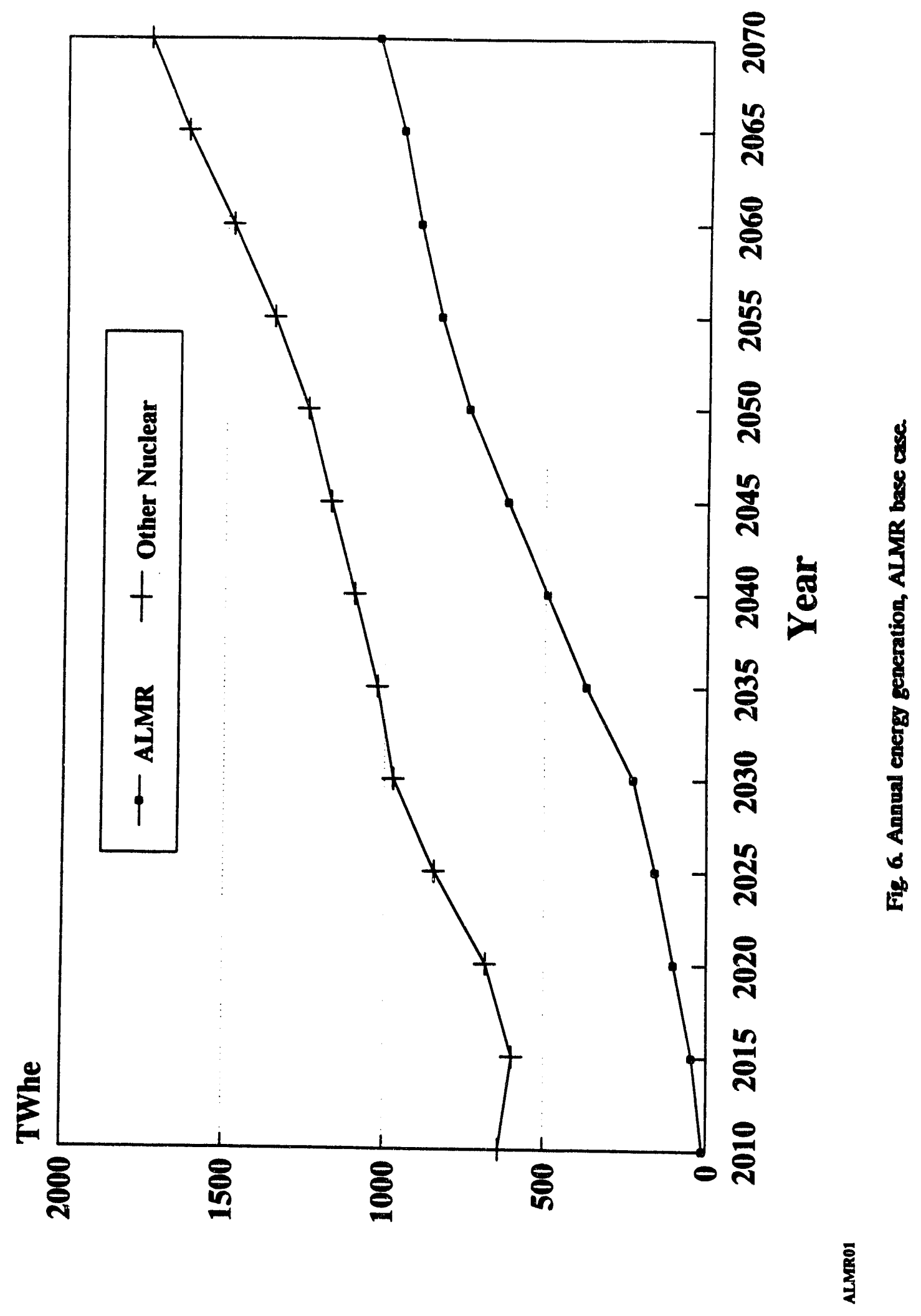




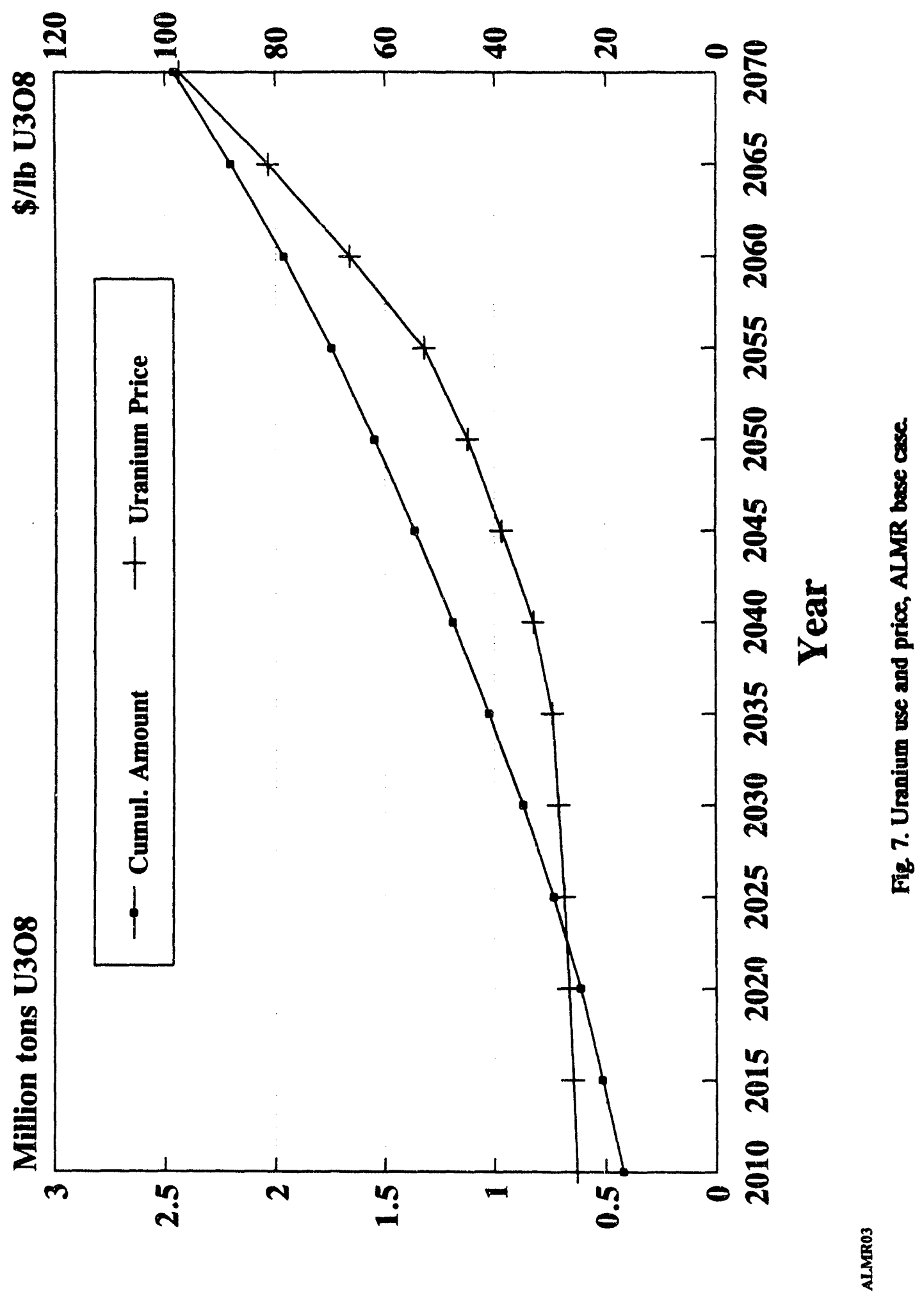




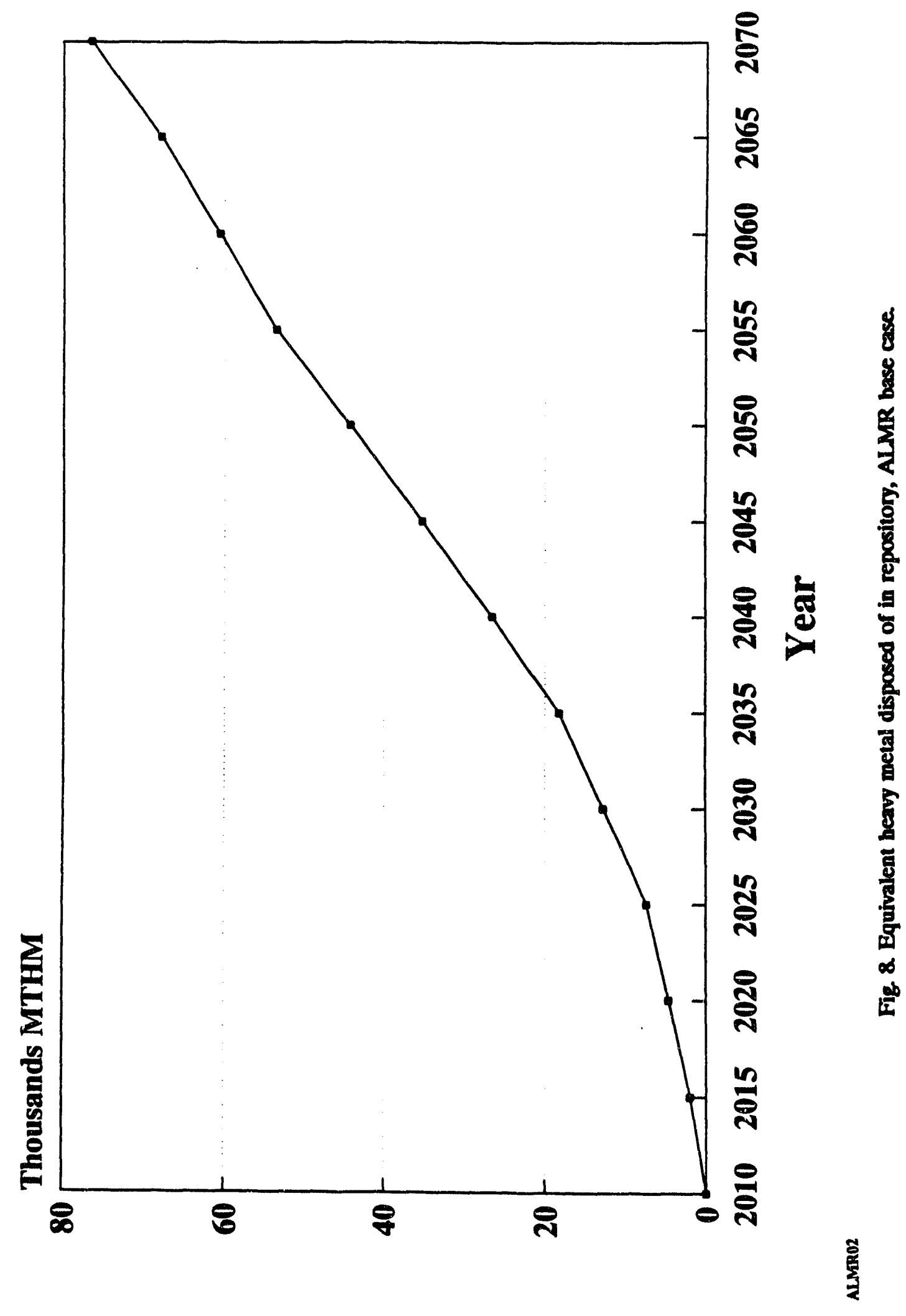




\section{Table 12}

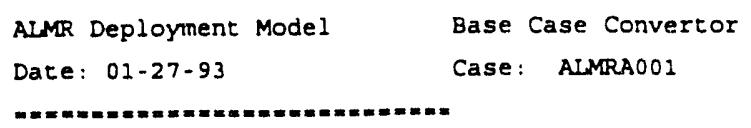

ALMR Levelized Plant Costs, mills/kWh

\begin{tabular}{|c|c|c|c|c|}
\hline 2030 & 2040 & 2050 & 2060 & 2070 \\
\hline -.... & $\cdots$ & $\cdots$ & .... & -.... \\
\hline 31.5 & 27.9 & 24.8 & 22.2 & 20.3 \\
\hline 8.9 & 8.5 & 8.3 & 8.2 & 8.2 \\
\hline 2.1 & 2.1 & 2.1 & 2.1 & 2.1 \\
\hline 16.7 & 15.5 & 14.4 & 13.7 & 13.2 \\
\hline
\end{tabular}

Fuel cost levelized over

all nuclear generation, mills/kWh

2010 to:

$\begin{array}{lllll}2030 & 2040 & 2050 & 2060 & 2070\end{array}$

[...

$\begin{array}{lllll}9.09 & 9.36 & 9.58 & 9.78 & 10.02\end{array}$

$\begin{array}{lllll}1.00 & 1.00 & 1.00 & 1.00 & 1.00\end{array}$

$\begin{array}{llllll}8.09 & 8.36 & 8.58 & 8.78 & 9.02\end{array}$

less wate fee

Net fuel cost

H. L. waste repository

Total Levelized Fuel Cost

$\begin{array}{llllll}0.32 & 0.35 & 0.37 & 0.37 & 0.39\end{array}$

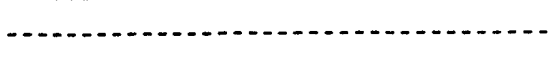

Decade Levelized Costs

\begin{tabular}{|c|c|c|c|c|c|c|}
\hline $\begin{array}{l}\text { Year Start } \\
\text { Year End }\end{array}$ & $\begin{array}{l}2010- \\
2020\end{array}$ & $\begin{array}{l}2021- \\
2030\end{array}$ & $\begin{array}{l}2031- \\
2040\end{array}$ & $\begin{array}{l}2041- \\
2050\end{array}$ & $\begin{array}{l}2051- \\
2060\end{array}$ & $\begin{array}{l}2061- \\
2070\end{array}$ \\
\hline & & -..... & $\cdots$ & 年 & $\ldots$ & -1 \\
\hline 1181 & 09 & 8.78 & 9.44 & 9.90 & 10.36 & .90 \\
\hline
\end{tabular}




\section{Table 13}

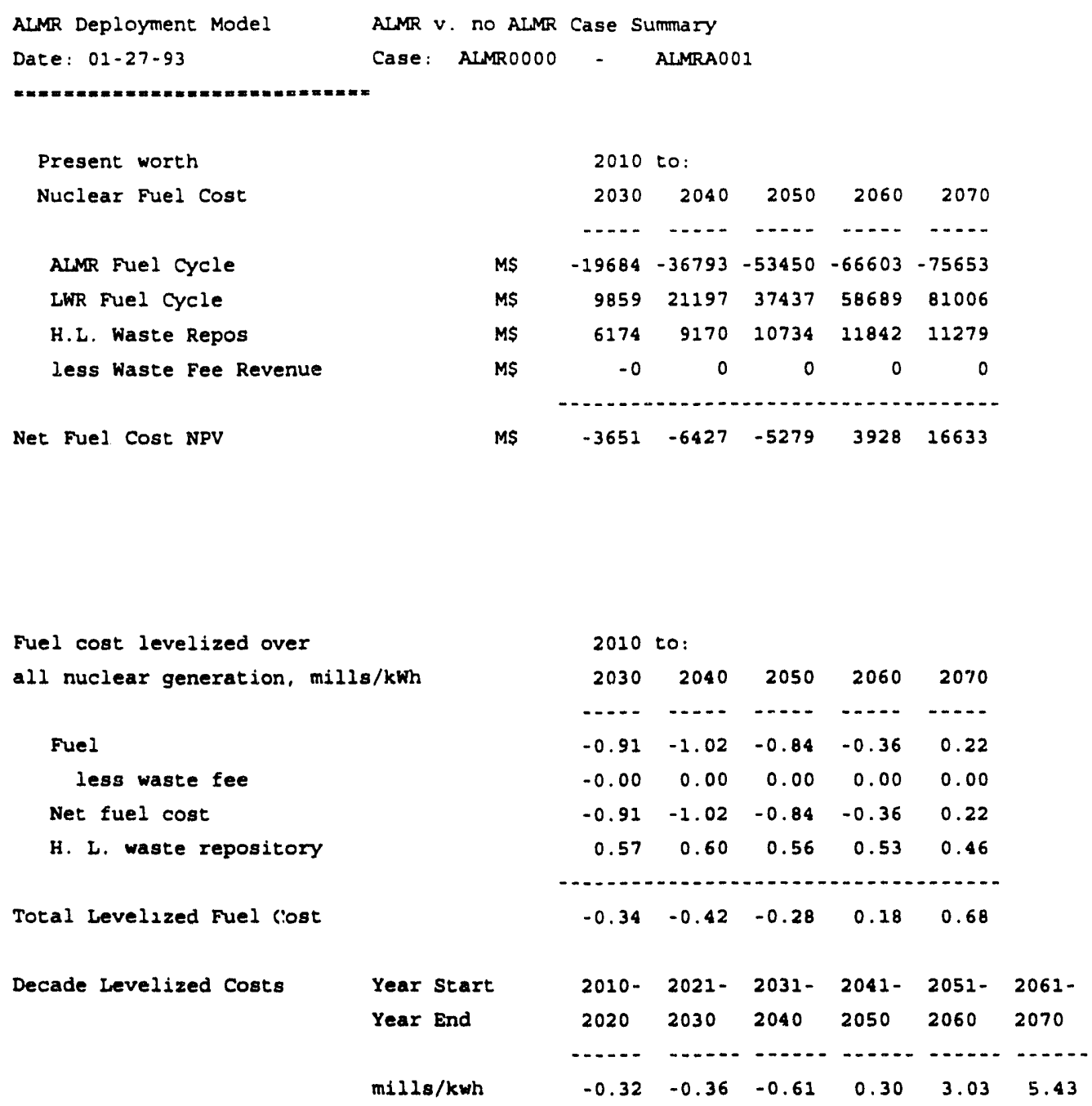


later years the price of uranium increases faster than ALMR fuel costs, leading to a $\$ 16.6$ billion (1992\$) net present value (NPV) advantage for the ALMR case over the 2010-2070 period.

\section{BURNER WITH DEFENSE Pu}

This case uses the same data as the ALMR Base Case discussed in the previous section except that $100 \mathrm{MT}$ of defense-related plutonium is assumed to be made available to the ALMR system at no cost for the fissile material. The energy generation, uranium demands, and repository requirements are nearly identical to those shown in Figs. 6-8. Therefore, plots for this case have not been included in this report. The cost summaries are given in Tables 14 and 15. As shown in Table 15, there is an increased economic benefit of ALMRs relative to the no ALMR case due to the availability of fissile material at zero cost and the resulting delay in the need for LWR reprocessing. The differential NPV between this case and the null (no ALMR) case is \$23.1 billion over the period 2010-2070.

\section{MAXIMUM DEPLOYMENT OF BURNER}

This case utilizes the same base burner data, but rather than constraining the number of ALMR plants to $\sim 27 \mathrm{GWe}$ in 2030 , the maximum possible number of ALMR plants by 2030 are deployed. This deployment is limited only by the amount of fissile material available for starting up and sustaining the ALMR plants. This leads to $61 \mathrm{GWe}$ of ALMR capacity in 2030 as compared to $27 \mathrm{GWe}$ in the constrained base burner case described in Sect. 2.2. The additional ALMR generation is fueled by actinides recovered from LWR spent fuel. As shown in the cost summaries (Tables 16 and 17), the increased utilization and advanced timing of LWR reprocessing lowers the relative economics of this case compared to the cases in Sects. 2.2 and 2.3.

\section{BURNER AT 75\% CAPACITY FACTOR}

This case utilizes the same base burner data, but the ALMR plant capacity factor was changed from $86 \%$ in the base case to $\sim 75 \%$ in this case. As shown in the cost summaries (Tables 18 and 19), the decreased capacity factor causes the power from ALMRs to be somewhat more expensive since fixed costs (such as capital) are spread over less power generation, so that the relative economics of this case is less compared to the cases in Sects. 2.2 and 2.3. The differential NPV between this case and the null (no ALMR) case is $\mathbf{\$ 1 5 . 0}$ billion over the period 2010-2070.

\section{BURNER AT 80\% CAPACITY FACTOR}

This case utilizes the same base burner data, but the ALMR plant capacity factor was changed from $86 \%$ in the base case to $-80 \%$ in this case. As shown in the cost summaries (Tables 20 and 21), the decreased capacity factor causes the power from ALMRs to be somewhat more expensive so that the relative economics of this case is less compared to the case in Sect. 2.2. The results indicate a NPV advantage for this case compared to the no ALMR case of $\$ 16.3$ billion over the 2010-2070 period. 
Table 14

$\begin{array}{ll}\text { ALMR Deployment Model } & \text { Base Case Convertor with DP PU } \\ \text { Date: } 01-27-93 & \text { Case: ALMRA002 }\end{array}$

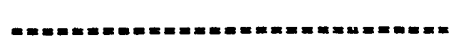

Present worth at utility COM, Ref. year $\$ 2010$ to:

$2030 \quad 2040 \quad 2050 \quad 2060 \quad 2070$

[...

ALMR Power

$\begin{array}{lllll}1182 & 2408 & 3799 & 5010 & 5927\end{array}$

LWR Power

Total Nuclear Power

$\begin{array}{lrrrrr}\text { TWh } & 1182 & 2408 & 3799 & 5010 & 5927 \\ \text { TWh } & 9621 & 12949 & 15368 & 17193 & 18614\end{array}$

$\begin{array}{llllll}\text { TWh } & 10803 & 15357 & 19168 & 22203 & 24541\end{array}$

Present worth

Nuclear Fuel Cost

ALMR Fuel cycle

LWR Fuel cycle

H.L. Waste Repos

$\begin{array}{lllll}10803 & 15357 & 19168 & 22203 & 24541\end{array}$

less Waste Fee Revenue

Net Fuel Cost NPV

\begin{tabular}{lrrrrr}
\multicolumn{8}{c}{2010} & to: & & & \\
& 2030 & 2040 & 2050 & 2060 & 2070 \\
MS & 14123 & 31532 & 48987 & 62774 & 72461 \\
MS & 78498 & 106708 & 129242 & 148758 & 167536 \\
MS & 2497 & 4624 & 6436 & 7480 & 8915 \\
MS & 10803 & 15357 & 19168 & 22203 & 24541 \\
& $\ldots \ldots \ldots$ & $\ldots$ & $\ldots$ & $\ldots$ & \\
MS & 84315 & 127507 & 165498 & 196809 & 224371
\end{tabular}

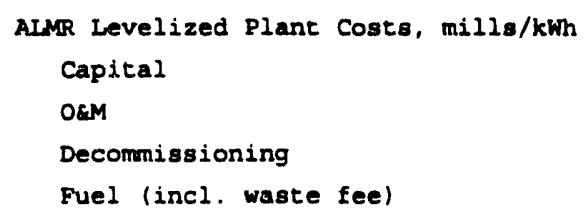

ALMR Levelized Plant Costs, mills/kWh Capital

OEM

Decommissioning

Fuel (incl. waste fee)

Total Levelized ALMR Plant Cost

Fuel cost levelized over all nuclear generation, mills/kkh

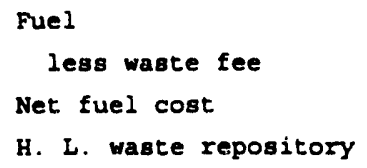

Total Levelized Fuel Cost

Decade Levelized Costs
Year Start Year End

m11le/kwh

\begin{tabular}{|c|c|c|c|c|}
\hline 2030 & 2040 & 2050 & 2060 & 2070 \\
\hline 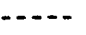 & $\ldots$ & $\ldots$. & $-\cdots$ &.--- \\
\hline 31.5 & 28.0 & 24.9 & 22.3 & 20.3 \\
\hline 8.9 & 8.5 & 8.3 & 8.2 & 8.2 \\
\hline 2.1 & 2.1 & 2.1 & 2.1 & 2.1 \\
\hline 12.0 & 13.1 & 12.9 & 12.5 & 12.2 \\
\hline 54.4 & 51.6 & 48.2 & 45.1 & 42.8 \\
\hline
\end{tabular}

\begin{tabular}{|c|c|c|c|c|c|}
\hline 2030 & 2040 & 2050 & 2060 & 2070 & \\
\hline$-\cdots$ & $-\cdots$ & $\cdots$ & $\ldots$. & $-\cdots$ & \\
\hline 8.57 & 9.00 & 9.30 & 9.53 & 9.78 & \\
\hline 1.00 & 2.00 & 1.00 & 1.00 & 1.00 & \\
\hline 7.57 & 8.00 & 8.30 & 8.53 & 8.78 & \\
\hline 0.23 & 0.30 & 0.34 & 0.34 & 0.36 & \\
\hline$\ldots$ & $\cdots$ & $\ldots$ & $\ldots-\cdots$ & 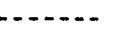 & \\
\hline 7.81 & B. 30 & 8.63 & 8.86 & 9.14 & \\
\hline $2010-$ & $2021-$ & $2031-$ & $2041-$ & 2051- & $2061-$ \\
\hline 2020 & 2030 & 2040 & 2050 & 2060 & 2070 \\
\hline$\ldots$ & $\cdots+\cdots$ & $\cdots$ & $\cdots$ & $\ldots$ & $\cdots$ \\
\hline 7.20 & 8.52 & 9.48 & 9.97 & 10.32 & 21.79 \\
\hline
\end{tabular}




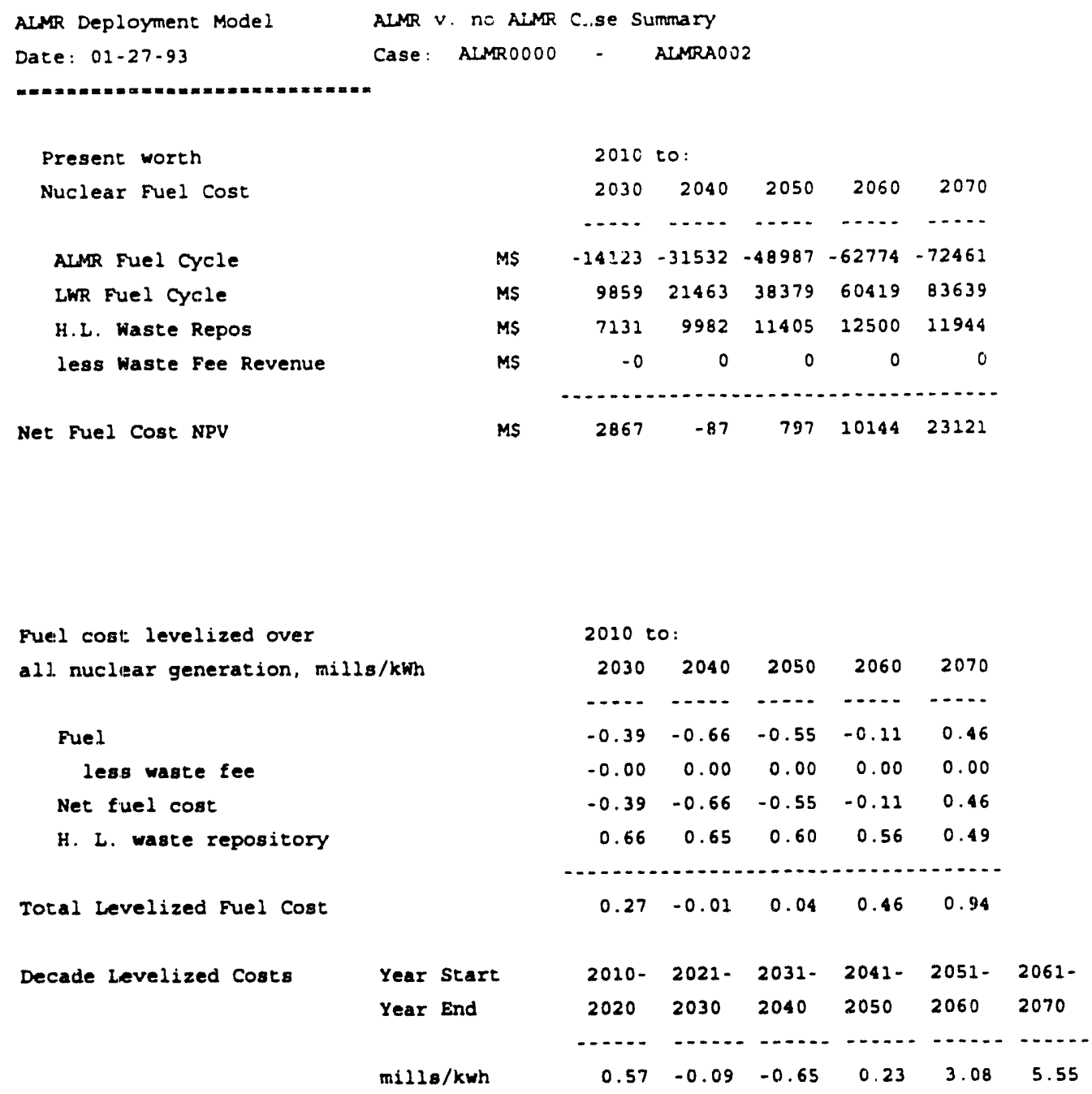




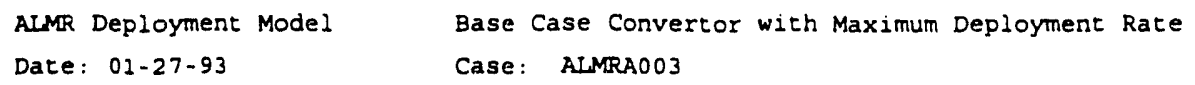

Present worth Nuclear Fuel Cost

ALMR Fuel Cycle

LWR Euel Cycle

H.L. Waste Repos

less Waste Fee Revenue

Net Fuel Cost NPV

\begin{tabular}{lrrrrr}
\multicolumn{8}{c}{2010 to: } & & & \\
& 2030 & 2040 & 2050 & 2060 & 2070 \\
MS & 35689 & 56083 & 70314 & 81276 & 89960 \\
M\$ & 69390 & 93726 & 116409 & 137268 & 156941 \\
M\$ & 5994 & 7632 & 8682 & 9552 & 11041 \\
MS & 10803 & 15357 & 19168 & 22203 & 24541 \\
& $\ldots \ldots \ldots$ & $\ldots \ldots$ & $\ldots \ldots$ & $\ldots$ \\
M\$ & 100272 & 142085 & 176237 & 205893 & 233400
\end{tabular}

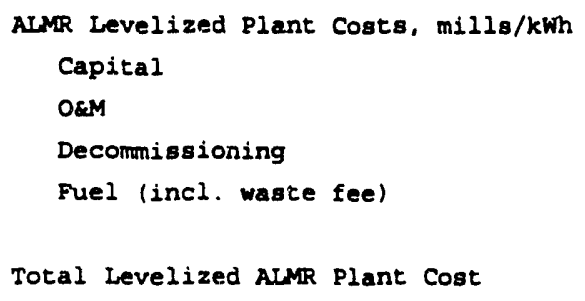

Decade Levelized Costs

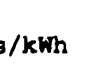

/kWh


Table 17

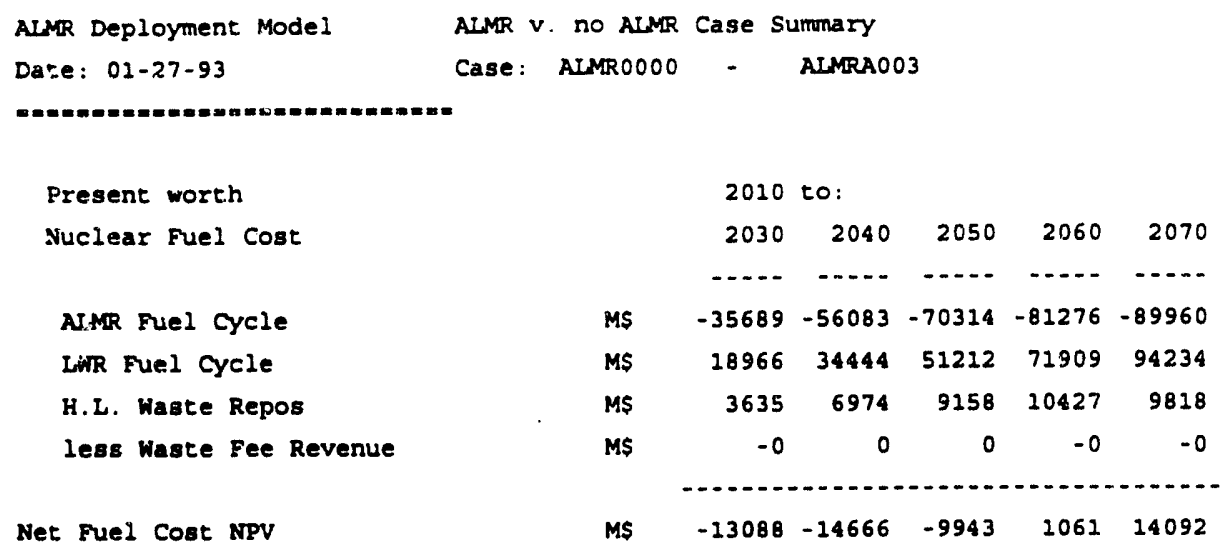

Fuel coat levelized over

all nuclear generation, mills/kWh

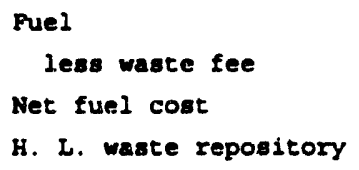


Table 18

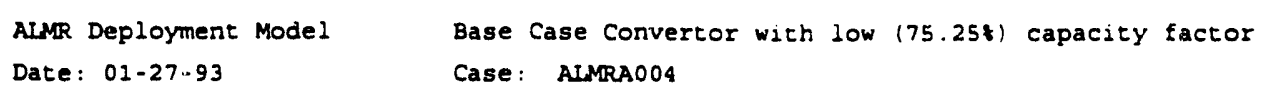

ALAR Levelized Plant CoBts, mills/kWh Capital

OEM

Decommiasioning

Fuel (incl. waste fee)

Total Levelized ALMR Plant Cost

\begin{tabular}{|c|c|c|c|c|c|}
\hline & 2030 & 2040 & 2050 & 2060 & 2070 \\
\hline & $\cdots$ & - ... & $\cdots$ & $\ldots$ & $\cdots$ \\
\hline MS & 18262 & 33666 & 49418 & 62179 & 71509 \\
\hline MS & 79727 & 109435 & 134007 & 155660 & 176099 \\
\hline MS & 3154 & 5183 & 6829 & 7923 & 9430 \\
\hline MS & 10803 & 15357 & 19168 & 22203 & 24541 \\
\hline
\end{tabular}

Fuel cost levelized over all nuclear generation, $\mathrm{mills} / \mathrm{km}$

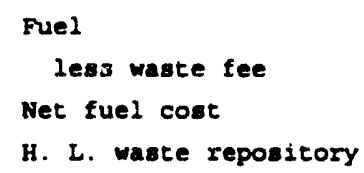




\section{Table 19}

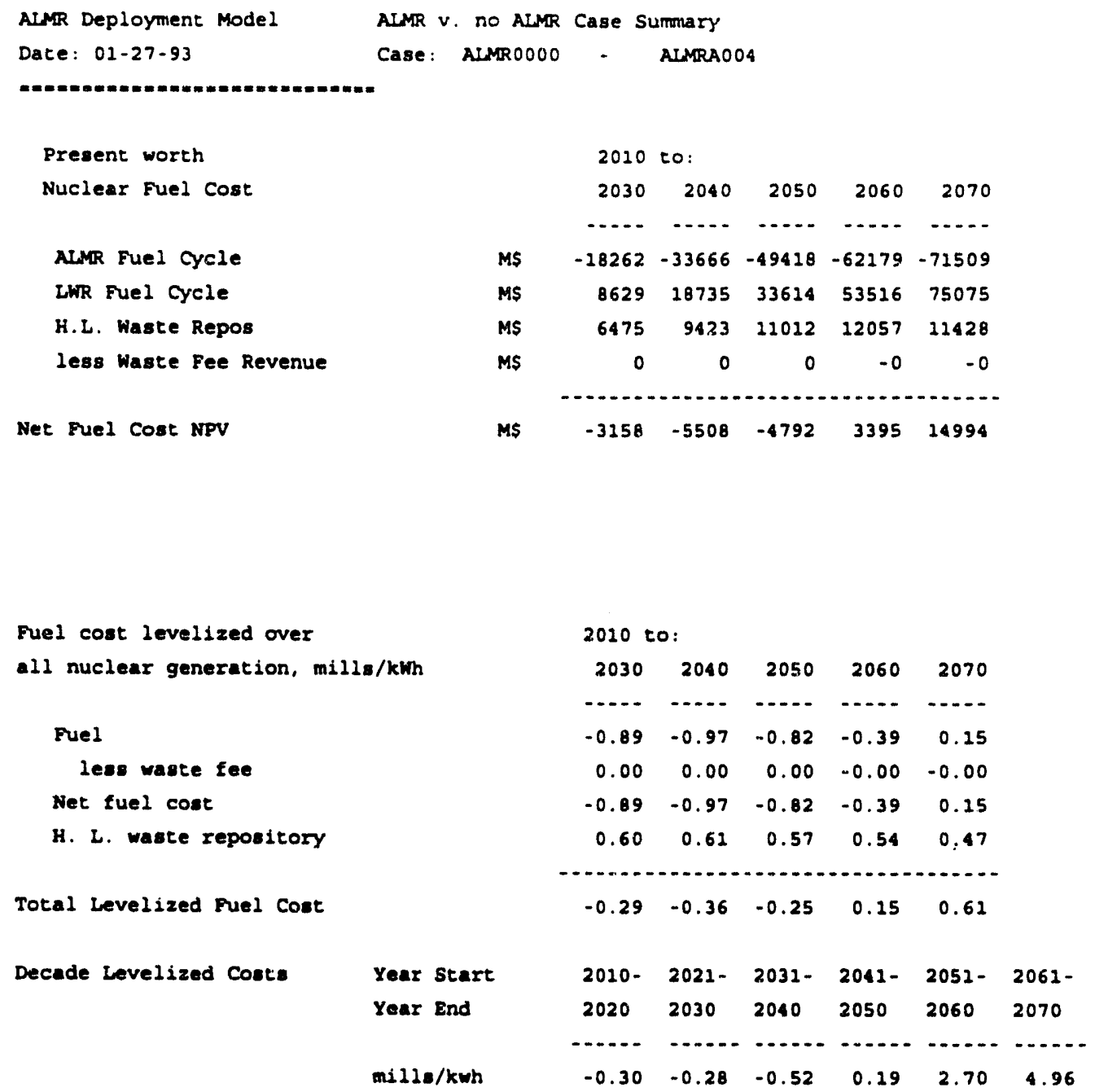




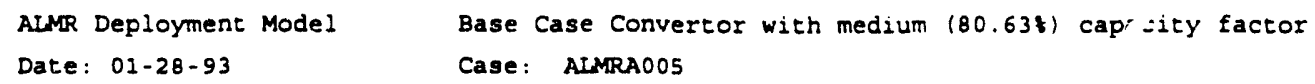

Present worth

Nuclear Fuel Cost

AlMR Fuel Oycle

LWR Fuel Cycle

H.L. Waste Repos

less Waste Fee Revenue

Net Fuel Cost NPV

\begin{tabular}{|c|c|c|c|c|c|}
\hline & 2030 & 2040 & 2050 & 2060 & 2070 \\
\hline & $\cdots$ & $\ldots-$ & $\cdots-$ & $\cdots$ & $\cdots$ \\
\hline MS & 19167 & 34997 & 51026 & 64125 & 73554 \\
\hline MS & 72073 & 108268 & 132113 & 152905 & 172738 \\
\hline MS & 316.3 & 5203 & 6861 & 7965 & 9445 \\
\hline \multirow[t]{2}{*}{ MS } & 10803 & 15357 & 19168 & 22203 & 24541 \\
\hline & & & & & (2) \\
\hline MS & 90601 & 133111 & 170832 & 202792 & 231196 \\
\hline
\end{tabular}

ALMR Levelized Plant Costs, milla/km Capital

ocM

Decomissioning

Fuel (incl. waste fee)

Total Levelized AIXR Plant Cost

Fuel cost levelized over

all nuclear generation, $\mathrm{mills} / \mathrm{kWh}$

Fuel

less waste fee

Net fuel cost

H. L. waste repository

Total Levelized Fuel Coet

Year start

Decade Levelized Costs

Year End

$m i 18 / \mathrm{kwh}$

2010 to:

\begin{tabular}{|c|c|c|c|c|}
\hline 2030 & 2040 & 2050 & 2060 & 2070 \\
\hline$--\infty$ & $\cdots$ & $\cdots$ & $\cdots+\cdots$ & $\cdots$ \\
\hline 33.5 & 29.7 & 26.5 & 23.8 & 21.8 \\
\hline 9.5 & 9.0 & 8.8 & 8.8 & 8.7 \\
\hline 2.2 & 2.2 & 2.2 & 2.2 & 2.2 \\
\hline 17.3 & 25.8 & 14.7 & 14.0 & 13.5 \\
\hline
\end{tabular}

2010 to:

\begin{tabular}{|c|c|c|c|c|}
\hline 2030 & 2040 & 2050 & 2060 & 2070 \\
\hline$\cdots$ & $\ldots$ & $\cdots$ & --- & $\cdots$ \\
\hline 9.09 & 9.33 & 9.55 & 9.77 & 10.04 \\
\hline 1.00 & 1.00 & 1.00 & 1.00 & 1.00 \\
\hline 8.09 & 8.33 & 8.55 & 8.77 & 9.04 \\
\hline 0.29 & 0.34 & 0.36 & 0.36 & 0.38 \\
\hline 8.39 & 8. 67 & 8.91 & 9.13 & 9.42 \\
\hline
\end{tabular}

\begin{tabular}{|c|c|c|c|c|c|}
\hline 2010 - & 2021- & $\begin{array}{l}2031- \\
2040\end{array}$ & $\begin{array}{l}2041- \\
2050\end{array}$ & $\begin{array}{l}2051- \\
2060\end{array}$ & $2061-$ \\
\hline & & & & & \\
\hline & 8.76 & 9.33 & 9.90 & 20.53 & 22 \\
\hline
\end{tabular}


Table 21

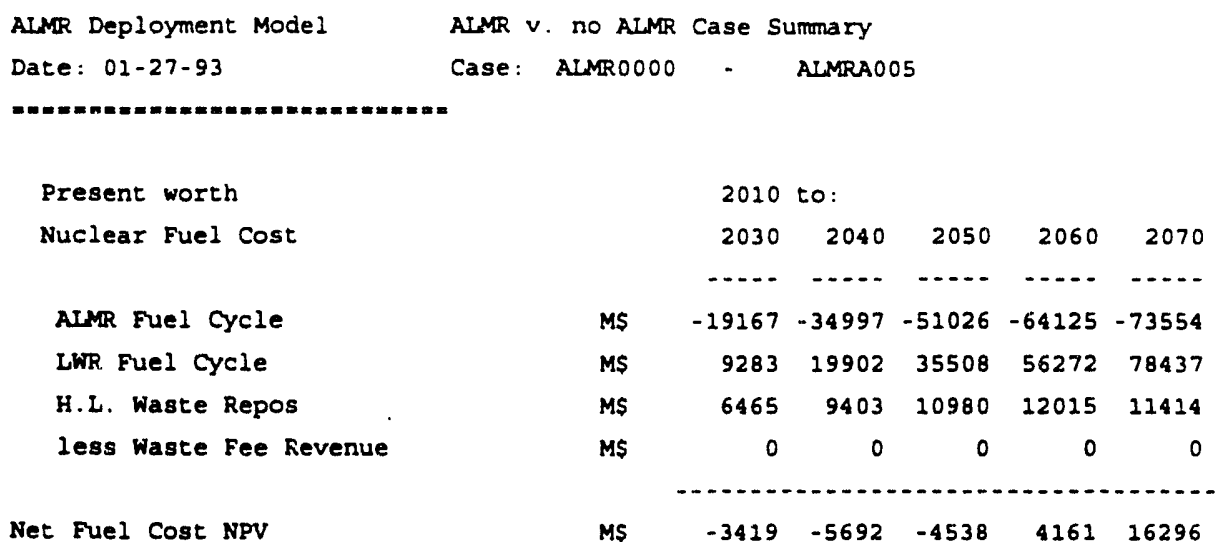

Fuel cost levelized over

all nuclear generation, mills/kwh

2010 to:

$\begin{array}{lllll}2030 & 2040 & 2050 & 2060 & 2070\end{array}$

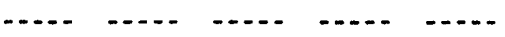

$\begin{array}{lllll}-0.91 & -0.98 & -0.81 & -0.35 & 0.20\end{array}$

$\begin{array}{llllll}0.00 & 0.00 & 0.00 & 0.00 & 0.00\end{array}$

$\begin{array}{llllll}-0.91 & -0.98 & -0.81 & -0.35 & 0.20\end{array}$

$\begin{array}{lllll}0.60 & 0.61 & 0.57 & 0.54 & 0.47\end{array}$

Net fuel cost
H. L. waste repository

Total Levelized Fuel Cost

$\begin{array}{lllll}-0.32 & -0.37 & -0.24 & 0.19 & 0.66\end{array}$

Decade Levelized Costs

Year Start

2010- 2021- 2031- 2041- 2051- 2061-

Year End

$\begin{array}{llllll}2020 & 2030 & 2040 & 2050 & 2060 & 2070\end{array}$

$\mathrm{mills/ \textrm {kwh }}$

[.... -

$\begin{array}{llllll}-0.30 & -0.33 & -0.50 & 0.30 & 2.87 & 5.19\end{array}$ 


\section{BURNER WITH \$200/KG LWR REPROCESSING}

This case is exactly the same as the base case ALMR burner (Sect. 2.2) except that the assumed cost of LWR spent fuel reprocessing was changed from $\$ 350 / \mathrm{kgHM}$ to $\$ 200 / \mathrm{kgHM}$. The power plant, fuel cycle facilities and repository deployment were unchanged from the base case. As shown in the cost summaries (Tables 22 and 23), the decreased reprocessing cost causes the ALMR fuel cost to be less expensive so that the relative economics of this case is better compared to the case in Sect. 2.2. The differential NPV between this case and the base case with $\$ 350 / \mathrm{kgHM}$ is $\$ 13.9$ billion demonstrating the sensitivity of the results to the cost of LWR fuel reprocessing. The results indicate a NPV advantage for this case compared to the no ALMR case of $\$ 30.6$ billion over the 2010-2070 period.

\section{BURNER WITH \$1000/KG LWR REPROCESSING}

This case is exactly the same as the base case ALMR burner (Sect. 2.2) except that the assumed cost of LWR spent fuel reprocessing was changed from $\$ 350 / \mathrm{kgHM}$ to $\$ 1000 / \mathrm{kgHM}$. As with the case in Sect. 2.7, the power plant, fuel cycle facilities and repository deployment were unchanged from the base case. As shown in the cost summaries (Tables 24 and 25), the increased reprocessing cost causes the ALMR fuel cost to be significantly more expensive so that the relative economics of this case are much worse compared to the case in Sect. 2.2. The differential NPV between this case

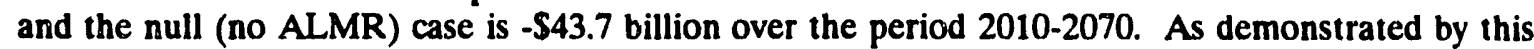
case and the one in Sect. 2.7, the economic viability of the ALMR is greatly influenced by cost of reprocessing spent fuel from $L W R$.

\section{BURNER WITH 0.5 WASTE EQUIVALENT MASS FACTOR}

This case is exactly the same as the base case ALMR burner (Sect. 2.2) except that the assumption on the effective repository capacity when disposing of reprocessing wastes as compared to intact LWR assembly disposal was changed. This case assumes that the repository can accommodate only two times the waste quantity as compared to the base assumption that a repository could handle four times as much reprocessing wastes as intact assemblies (based on initial heavy metal). ALMR plant and infrastructure deployment and uranium use and price is unchanged in this case compared to the base case. The number of repositories needed is increased compared to the base case with the second repository coming on line in 2044 and a third in 2062.

The resulting costs for this case are shown in Table 26. The differential costs, comparing this case to the no ALMR case, are provided in Table 27. The results indicate a NPV advantage for this case compared to the no ALMR case of $\$ 15.0$ billion over the 2010-2070 period. This is approximately $\$ 1.7$ billion less than the ALMR base case.

\section{BURNER WITH 0.5 REPOSTTORY DISPOSAL COST FACTOR}

This case is exactly the same as the base case ALMR burner (Sect. 2.2) except that the variable cost of disposing of reprocessing wastes compared to intact LWR spent fuel assembly wastes was 0.5 instead of 0.75 in the base case. The power plant, fucl cycle facilities and repository deployment were unchanged from the base case. As shown in the cost summaries (Tables 28 and 29), 
Table 22

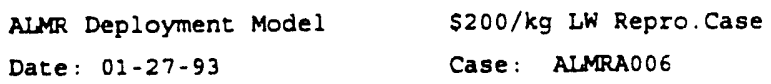

\begin{tabular}{lrrrrr}
\multicolumn{8}{c}{2010 to: } & & & \\
& 2030 & 2040 & 2050 & 2060 & 2070 \\
MS & 14987 & 28445 & 42229 & 53612 & 61721 \\
MS & 78498 & 106974 & 130185 & 150488 & 170168 \\
MS & 3454 & 5437 & 7107 & 8138 & 9579 \\
MS & 10803 & 15357 & 19168 & 22203 & 24541 \\
& $\ldots$ & $\ldots \ldots$ & $\ldots \ldots$ & $\ldots$. & $\ldots \ldots$ \\
MS & 86137 & 125498 & 160352 & 190034 & 216927
\end{tabular}

AIMR Levelized Plant Costs, mills/kWh Capital

OrM

Decommissioning

Fuel (incl. waste fee)

Total Levelized ALMR Plant Cost

Fuel cost levelized over

all nuclear generation, mills/kwh

Fuel

less waste fee

Net fuel cost

H. I. waste repository

Total Levelized fuel Cost

Decade Levelized Costs

Year Start

Year End

mills/kwh
2010 to:

\begin{tabular}{|c|c|c|c|c|}
\hline 2030 & 2040 & 2050 & 2060 & 2070 \\
\hline$\ldots$ & $\cdots$ & $-\cdots$ & - & $\cdots$ \\
\hline 31.5 & 27.9 & 24.8 & 22.2 & 20.3 \\
\hline 8. 9 & 8.5 & 8.3 & 8.2 & 8. 2 \\
\hline 2.1 & 2.1 & 2.1 & 2.1 & 2.1 \\
\hline 12.7 & 12.0 & 11.4 & 11.0 & 10.8 \\
\hline
\end{tabular}

2010 to:

$\begin{array}{lllll}2030 & 2040 \quad 2050 \quad 2060 \quad 2070\end{array}$

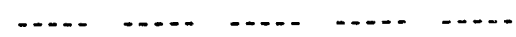

$\begin{array}{lllll}8.65 & 0.82 & 8.99 & 9.19 & 9.45\end{array}$

$\begin{array}{llllll}1.00 & 1.00 & 1.00 & 1.00 & 1.00\end{array}$

$\begin{array}{llllll}7.65 & 7.82 & 7.99 & 8.19 & 8.45\end{array}$

$\begin{array}{lllll}0.32 & 0.35 & 0.37 & 0.37 & 0.39\end{array}$

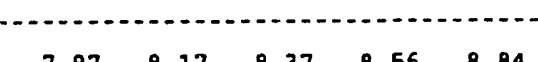

2010- 2021-2031- 2041- 2051-2061-

$\begin{array}{llllll}2020 & 2030 & 2040 & 2050 & 2060 & 2070\end{array}$

....

$\begin{array}{llllll}7.73 & 8.25 & 8.64 & 9.15 & 9.78 & 11.50\end{array}$ 
Table 23

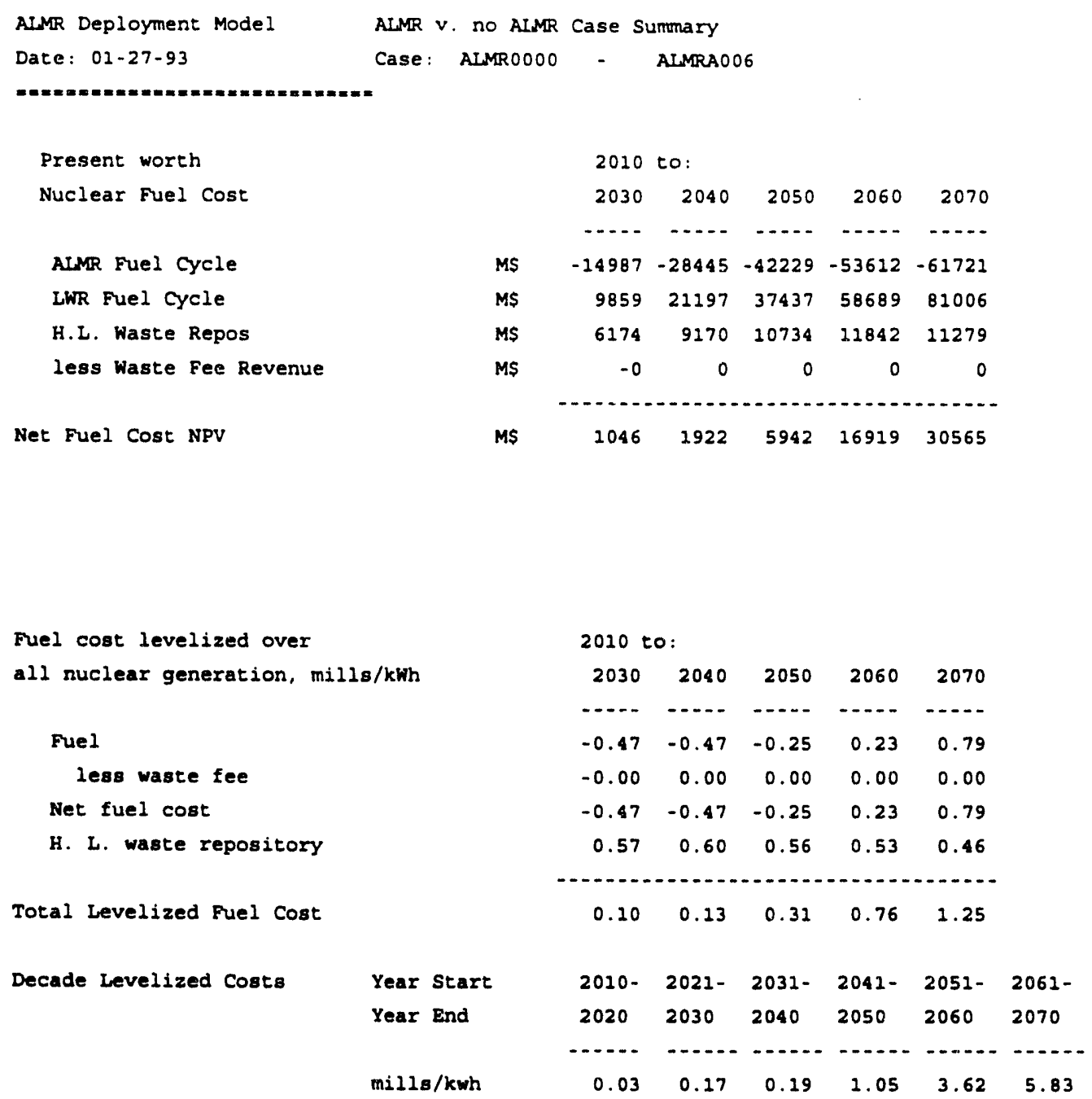


Table 24

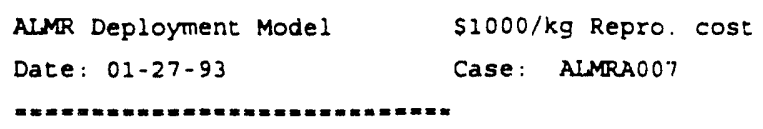

\begin{tabular}{lrrrrr}
\multicolumn{8}{c}{$\begin{array}{l}2010 \\
\end{array} \quad 2030$} & 2040 & 2050 & 2060 & 2070 \\
MS & 40039 & 72970 & 102074 & 122897 & 136024 \\
MS & 78498 & 106974 & 130185 & 150488 & 170168 \\
MS & 3454 & 5437 & 7107 & 8138 & 9579 \\
MS & 10803 & 15357 & 19168 & 22203 & 24541 \\
& $\ldots \ldots \ldots$ & $\ldots \ldots$ & $\ldots \ldots$ & $\ldots \ldots$ & $\ldots \ldots$ \\
MS & 111188 & 170024 & 220198 & 259320 & 291230
\end{tabular}

ALMR Levelized Plant Costs, mills/kmh Capital

OCM

Decommissioning

Fuel (incl. waste fee)

Total Levelized ALMR Plant Cost

Fuel cost levelized over

all nuclear generation, mills/kwh

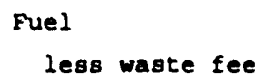

$\begin{array}{rrrrr}2010 & \text { to: } & & & \\ 2030 & 2040 & 1050 & 2060 & 2070 \\ 32.5 & 27.9 & 24.8 & 22.2 & 20.3 \\ 8.9 & 8.5 & 8.3 & 8.2 & 8.2 \\ 2.1 & 2.1 & 2.1 & 2.1 & 2.1 \\ 33.9 & 30.7 & 27.6 & 25.3 & 23.7 \\ 76.3 & 69.1 & 62.7 & 57.8 & 54.3\end{array}$

\begin{tabular}{|c|c|c|c|c|c|}
\hline 2030 & 2040 & 2050 & 2060 & 2070 & \\
\hline$-\ldots$ & $-\cdots$ & $\cdots$ & $--\cdot$ & $\ldots$ & \\
\hline 10.97 & 11.72 & 12.12 & 12.31 & 12.48 & \\
\hline 1.00 & 1.00 & 1.00 & 2.00 & 1.00 & \\
\hline 9.97 & 10.72 & 11.12 & 11.31 & 11.48 & \\
\hline 0.32 & 0.35 & 0.37 & 0.37 & 0.39 & \\
\hline 10.29 & 11.07 & 11.49 & 11.68 & 11.87 & \\
\hline $2010-$ & $2021-$ & $2031-$ & $2041-$ & $2051-$ & $2061-$ \\
\hline 2020 & 2030 & 2040 & 2050 & 2060 & 2070 \\
\hline$\cdots$ & 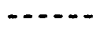 & $\ldots-$ & $\ldots \ldots$ & $\ldots$ & $\cdots$ \\
\hline 9.62 & 11.07 & 22.92 & 23.17 & 12.89 & 13.64 \\
\hline
\end{tabular}


Table 25

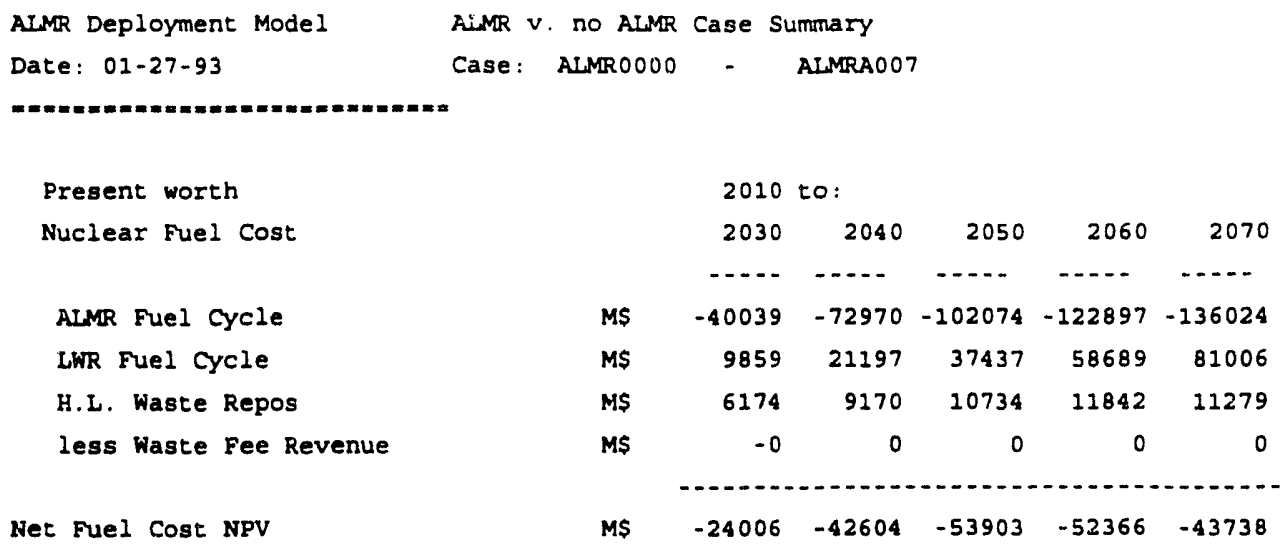

Fuel cost levelized over

ald nuclear generation, milis/kwh

2010 to:

$\begin{array}{ccccc}2030 & 2040 & 2050 & 2060 & 2070 \\ -\ldots . & -. .- & -\ldots . . & -.-. & -. .- \\ -2.79 & -3.37 & -3.37 & -2.89 & -2.24 \\ -0.00 & 0.00 & 0.00 & 0.00 & 0.00 \\ -2.79 & -3.37 & -3.37 & -2.89 & -2.24 \\ 0.57 & 0.60 & 0.56 & 0.53 & 0.46 \\ -2.22 & -2.77 & -2.81 & -2.36 & -1.78\end{array}$

Total Levelized Fuel Cost

Year Start

2010- 2021- 2031- 2041- 2051- 2061-

Decade Levelized Costs

Year End

$2020 \quad 2030 \quad 2040 \quad 2050$

20602070

[.... -

$\mathrm{mills} / \mathrm{kwh}$

$\begin{array}{lllll}-1.86 & -2.65 & -4.08 & -2.96 & 0.51\end{array}$

3.69 


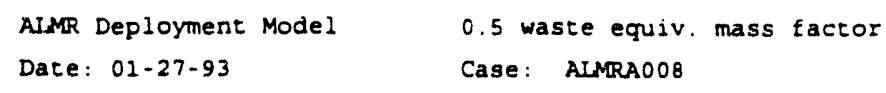

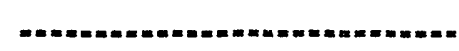

Present worth at utility COM, Ref. year $\$$

ALMR Power

LWR Power

Total Nuclear Power

Present worth

Nuclear Fuel Cost

ALMR Fuel Cycle

Litr Fuel Cycle

H.L. Waste Repos

less Waste Fee Revenue

Net Fuel Cost NPV
2010 to:

$2030 \quad 2040 \quad 2050 \quad 2060 \quad 2070$

....

$\begin{array}{lllll}1182 & 2377 & 3703 & 4857 & 5728\end{array}$

$\begin{array}{lllll}9621 & 12979 & 15464 & 17346 & 18813\end{array}$

$\begin{array}{llllll}10803 & 15357 & 19168 & 22203 & 24541\end{array}$

2010 to:

$20302040 \quad 2050 \quad 2060 \quad 2070$

[...

$\begin{array}{lllll}19684 & 36793 & 53450 & 66603 & 75653\end{array}$

$\begin{array}{lllll}78498 & 106974 \quad 130185 \quad 150488 \quad 170168\end{array}$

$\begin{array}{lllll}3454 & 5437 & 8754 & 9813 & 11238\end{array}$

$\begin{array}{lllll}10803 & 15357 & 19168 & 22203 & 24541\end{array}$

[.

$90834 \quad 133847 \quad 173220 \quad 204700 \quad 232517$

ALMR Levelized Plant Costs, mills/km

\begin{tabular}{|c|c|c|c|c|}
\hline 2030 & 2040 & 2050 & 2060 & 2070 \\
\hline$\cdots$ & $\cdots$ & $\cdots$ & $\ldots$ & $\ldots$ \\
\hline 32.5 & 27.9 & 24.8 & 22.2 & 20.3 \\
\hline 8.9 & 8.5 & 8.3 & 8.2 & 8.2 \\
\hline 2.1 & 2.1 & 2.1 & 2.1 & 2.1 \\
\hline 16.7 & 15.5 & 24.4 & 13.7 & 13.2 \\
\hline
\end{tabular}

Total Levelized AIMR Plant Cost

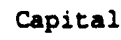

OCM

Decomissioning

Fuel (incl. waste fee)
Fuel cost levelized over

ald nuclear generation, millo/kwh

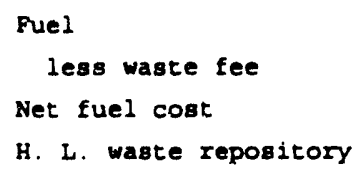

H. L. waste repository

Total Levelized Puel Cost

Decade Levelized Costs

$\begin{array}{lcccccc}\text { Year start } & 2010- & 2021- & 2031- & 2041- & 2051- & 2061- \\ \text { Year End } & 2020 & 2030 & 2040 & 2050 & 2060 & 2070 \\ & \ldots \ldots .- & \ldots \ldots . . & \ldots \ldots \ldots & \ldots \ldots \ldots \\ \text { mills/kwh } & 8.09 & 8.78 & 9.44 & 10.33 & 10.37 & 11.89\end{array}$


Table 27

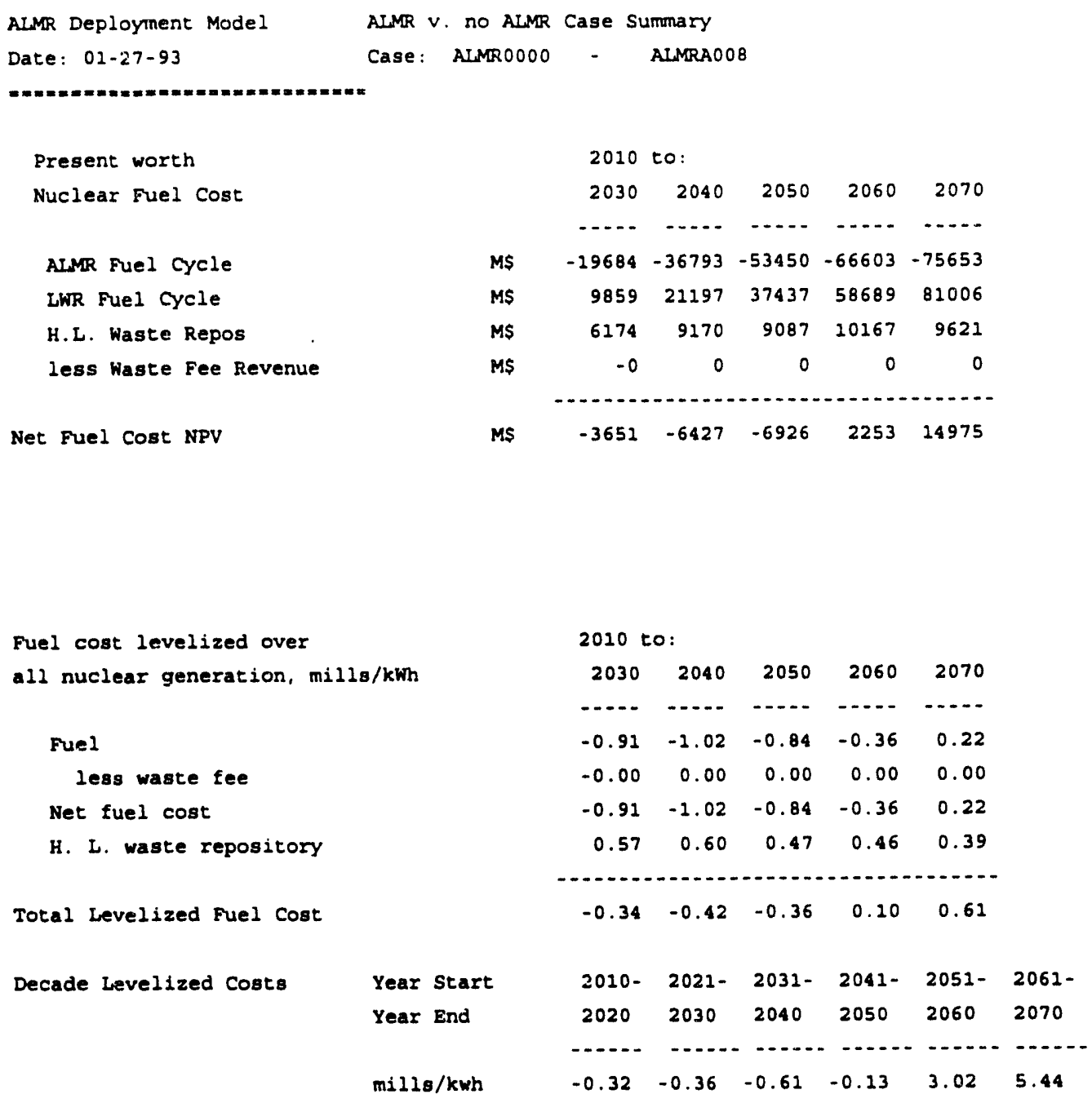




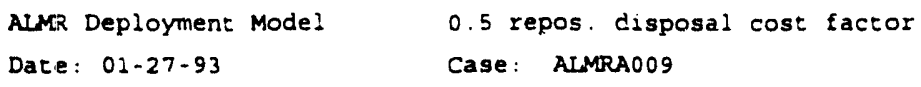

$\begin{array}{lrrrrr} & 2030 & 2040 & 2050 & 2060 & 2070 \\ & \ldots \ldots & \ldots \ldots & \ldots \ldots & \ldots . . & \ldots . . \\ \text { TWh } & 1182 & 2377 & 3703 & 4857 & 5728 \\ \text { TWh } & 9621 & 12979 & 15464 & 17346 & 18813 \\ \text { TWh } & 10803 & 15357 & 19168 & 22203 & 24541\end{array}$

ALMR Levelized Plant Costs, mills/kWh Capital

OEM

Deconmissioning

Puel (incl. waste fee)

Total Levelized ALMR Plant Cost

\begin{tabular}{|c|c|c|c|c|c|}
\hline & 2030 & 2040 & 2050 & 2060 & 2070 \\
\hline & $\cdots$ & 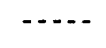 & $\ldots$ & $\cdots$ & $\cdots$ \\
\hline MS & 19684 & 36793 & 53450 & 66603 & 75653 \\
\hline MS & 78498 & 106974 & 130185 & 150488 & 170168 \\
\hline MS & 2396 & 3739 & 4867 & 5564 & 6798 \\
\hline MS & 10803 & 15357 & 29168 & 22203 & 24541 \\
\hline
\end{tabular}

Fuel cost levelized over

all nuclear generation, mills/kWh

Fuel

less waste fee

Net fuel cost

H. L. waste repository

Total Levelized Fuel cost

\begin{tabular}{|c|c|c|c|c|}
\hline 2030 & 2040 & 2050 & 2060 & 2070 \\
\hline$\ldots$ & $\ldots$ & $\ldots$ & $\ldots$ & $\ldots$ \\
\hline 31.5 & 27.9 & 24.8 & 22.2 & 20.3 \\
\hline B. 9 & 8.5 & 8.3 & 8.2 & 8.2 \\
\hline 2.1 & 2.1 & 2.1 & 2.1 & 2.1 \\
\hline 16.7 & 15.5 & 14.4 & 13.7 & 13.2 \\
\hline 59.1. & 53.9 & 49.6 & 46.2 & 43.7 \\
\hline
\end{tabular}

Decade Levelized Costs

$$
\begin{aligned}
& \text { Year Start } \\
& \text { Year End } \\
& \text { mills/kwh }
\end{aligned}
$$


Table 29

\begin{tabular}{|c|c|c|c|c|c|c|c|}
\hline $\begin{array}{l}\text { ALMR Deployment Model } \\
\text { Date: } 01-27-93\end{array}$ & $\begin{array}{l}\text { ALMR } \\
\text { Case : }\end{array}$ & $\begin{array}{l}\text { no ALMR } \\
\text { ALMR0000 }\end{array}$ & $\begin{array}{c}\text { Case Su } \\
-\end{array}$ & $\begin{array}{l}\text { Ummary } \\
\text { ALMRAOO }\end{array}$ & & & \\
\hline Present worth & & & 2010 & to: & & & \\
\hline Nuclear Fuel Cost & & & 2030 & 2040 & 2050 & 2060 & 2070 \\
\hline & & & $\cdots$ & $\ldots-$ & $\cdots+$ & $\cdots$ & $\ldots$ \\
\hline ALMR Fuel cycle & & MS & -19684 & -36793 & -53450 & -66603 & -75653 \\
\hline LWR Fuel Cycle & & MS & 9859 & 21197 & 37437 & 58689 & 81006 \\
\hline H.L. Waste Repos & & MS & 7233 & 10867 & 12974 & 14416 & 14061 \\
\hline less Waste Fee Revenue & & MS & -0 & 0 & 0 & 0 & 0 \\
\hline Net Fuel Cost NPV & & MS & -2593 & -4730 & -3039 & 6502 & 19414 \\
\hline
\end{tabular}

Fuel cost levelized over all nuclear generation, mills/kwh

Fuel

less waste fee

Net fuel cost

H. L. waste repository

Total Levelized Fuel Cost

Decade Levelized Costs

\begin{tabular}{|c|c|c|c|c|c|c|}
\hline & 2010 & to: & & & & \\
\hline \multirow{8}{*}{$\mathrm{s} / \mathrm{kWh}$} & 2030 & 2040 & 2050 & 2060 & 2070 & \\
\hline & $-\ldots$ & $\ldots$ & $\ldots$ & $\ldots$ & $\ldots$ & \\
\hline & -0.91 & -1.02 & -0.84 & -0.36 & 0.22 & \\
\hline & -0.00 & 0.00 & 0.00 & 0.00 & 0.00 & \\
\hline & -0.91 & -1.02 & -0.84 & -0.36 & 0.22 & \\
\hline & 0.67 & 0.71 & 0.68 & 0.65 & 0.57 & \\
\hline & $\ldots \ldots$ & . & $\ldots$ & - & ....... & \\
\hline & -0.24 & -0.31 & -0.16 & 0.29 & 0.79 & \\
\hline Year start & $2010-$ & 2021- & $2031-$ & $2041-$ & $2051-$ & $2061-$ \\
\hline Year End & 2020 & 2030 & 2040 & 2050 & 2060 & 2070 \\
\hline & -..... & ....... & $\ldots$ & -.... & $\ldots . .$. & $\ldots$ \\
\hline Ls/kwh & -0.24 & -0.24 & -0.47 & 0.44 & 3.14 & 5.52 \\
\hline
\end{tabular}


the ruduced cost factor results in improved economics for the waste repository for the ALMR deployment case. The results indicate a NPV advantage for this case compared to the no ALMR case of $\$ 19.4$ billion over the $2010-2070$ period. This is approximately $\$ 2.8$ billion more than the ALMR base case.

\section{BURNER WITH S15 BILLION FOLLOW-ON REPOSITORY COST}

This case is exactly the same as the base case ALMR burner (Sect. 2.2) except that the cost 0 ? the follow-on waste repositories was increased from the $\$ 7.2$ billion value in the base case to $\mathbf{S 1 5}$ billion in this case. The power plant, fuel cycle facilities and repository deployment were uni hanged from the base case. The change in the repository cost effects both this case and that for no ALMR deployment (Sect. 2.1).

The resulting costs for a $\$ 15$ billion repository cost for the no ALMR and ALMR cases are shown in Tables 30 and 31. The differential cost between these two cases are shown in Table 32. The increased repository cost results in increased costs for both ALMR and no ALMR deployment. The results indicate a NPV advantage for this case compared to the no ALMR case of $\$ 23.5$ billion over the $2010-2070$ period. This is approximately $\$ 6.9$ billion more than the differential for the ALMR base case.

\section{LWR REPROCESSING COST INCLUDED WITH WASTE SYSTEM}

This case is exactly the same as the base case ALMR burner (Sect. 2.2) except that LWR spent fuel reprocessing is made part of the waste disposal system. The cost of LWR spent fuel reprocessing was charged to the waste repository and the recovered actinides were provided at zero cost to the ' $-\mathrm{MR}$. The power plant, fuel cycle facilities, and repository deployment were unchanged from the base case. As shown in the cost summaries (Tables 33 and 34 ) and comparing these against the cost summaries for the base case (Tables 12 and 13), the ALMR fuel cost is decreased significantly and the repository costs are increased significantly. The results indicate a NPV advantage for this case compared to the no ALMR case of $\$ 24.5$ billion over the $2010-2070$ period. This is $\$ 7.9$ billion more than for the ALMR base case.

\section{BASE ALMR BREAKEVEN}

Alternate reactor fuel cycles were considered in addition to the base case burner. In this case, a breakeven fuel cycle with a breeding ratio of 1.04 was considered. All other cost factors were unchanged from the base case. A comparison of this fuel cycle with the base case was given in Table 8. The cost summaries ior this case (Tables 35 and 36 ) indicate an improvement over the base case burner (Tables 12 and 13). The results indicate a NPV advantage for this case compared to the no ALMR case of $\$ 19.5$ billion over the $2010-2570$ period. This is $\$ 2.9$ billion more than for the ALMR base case burner. 
Table 30

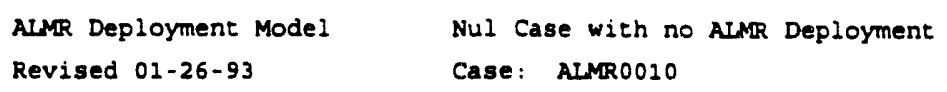

$\begin{array}{lrrrrr} & 2030 & 2040 & 2050 & 2060 & 2070 \\ & \ldots \ldots . & \ldots \ldots . & \ldots \ldots & \ldots \ldots & \ldots \ldots \\ \text { TWh } & 0 & 0 & 0 & 0 & 0 \\ \text { TWh } & 10803 & 15357 & 19168 & 22203 & 24541 \\ & 10803 & 15357 & 19168 & 22203 & 24541\end{array}$

Present worth

2010 to:

Nuclear Fuel Cost

ALAR Fuel cycle

LWR Fuel cycle

H.I. Waste Repos

less Waste Fee Revenue

$\begin{array}{lllll}2030 & 2040 & 2050 & 2060 & 2070\end{array}$ -....

$\begin{array}{rrrr}0 & 0.0 & & \\ 0 & 0 & 0 & 0\end{array}$

MS $\quad 88357128170 \quad 167622 \quad 209176 \quad 251175$

MS

$\begin{array}{lllll}12954 & 20102 & 24695 & 27721 & 28600\end{array}$

MS $\quad \begin{array}{llllll}10803 & 15357 & 19168 & 22203 & 24541\end{array}$

Net Fuel Cost NPV

ALMR Levelized Plant Costs, mills/km

\section{Capital}

ocM

Decomiseioning

Puel (incl. waste fee)

Total Levelized ALMR Plant Cost

Fuel cost levelized over

all nuclear generation, mills/kwh

$$
\text { Fuel }
$$

less waste fee

Net fuel cost

H. L. Wate repository

Total Levelized fuel cost

Decade Levelized Costs

\begin{tabular}{|c|c|c|c|c|c|c|}
\hline \multirow[t]{7}{*}{$\mathrm{ls} / \mathrm{kWh}$} & 2030 & 2040 & 2050 & 2060 & 2070 & \\
\hline & $\cdots$ & $\cdots$ & $\ldots$ & $\ldots$ & $\ldots$ & \\
\hline & 8.18 & 8.35 & 8.75 & 9.42 & 10.23 & \\
\hline & 1.00 & 1.00 & 1.00 & 1.00 & 1.00 & \\
\hline & 7.18 & 7.35 & 7.75 & B. 42 & 9.23 & \\
\hline & 1.20 & 1.31 & 1.29 & 1.25 & 1.17 & \\
\hline & 8.38 & 8.66 & 9.03 & 9.67 & 10.40 & \\
\hline Year Start & 2010- & $2021-$ & 2031- & $2041-$ & $2051-$ & $2061-$ \\
\hline Year End & 2020 & 2030 & 2040 & 2050 & 2060 & 2070 \\
\hline & $\cdots$ & $\ldots . .$. & $\cdots$ & $\cdots$ & $\ldots$. & $\cdots$ \\
\hline wille/kwh & 7.77 & 9.09 & 9.31 & 10.56 & 23.69 & 17.33 \\
\hline
\end{tabular}




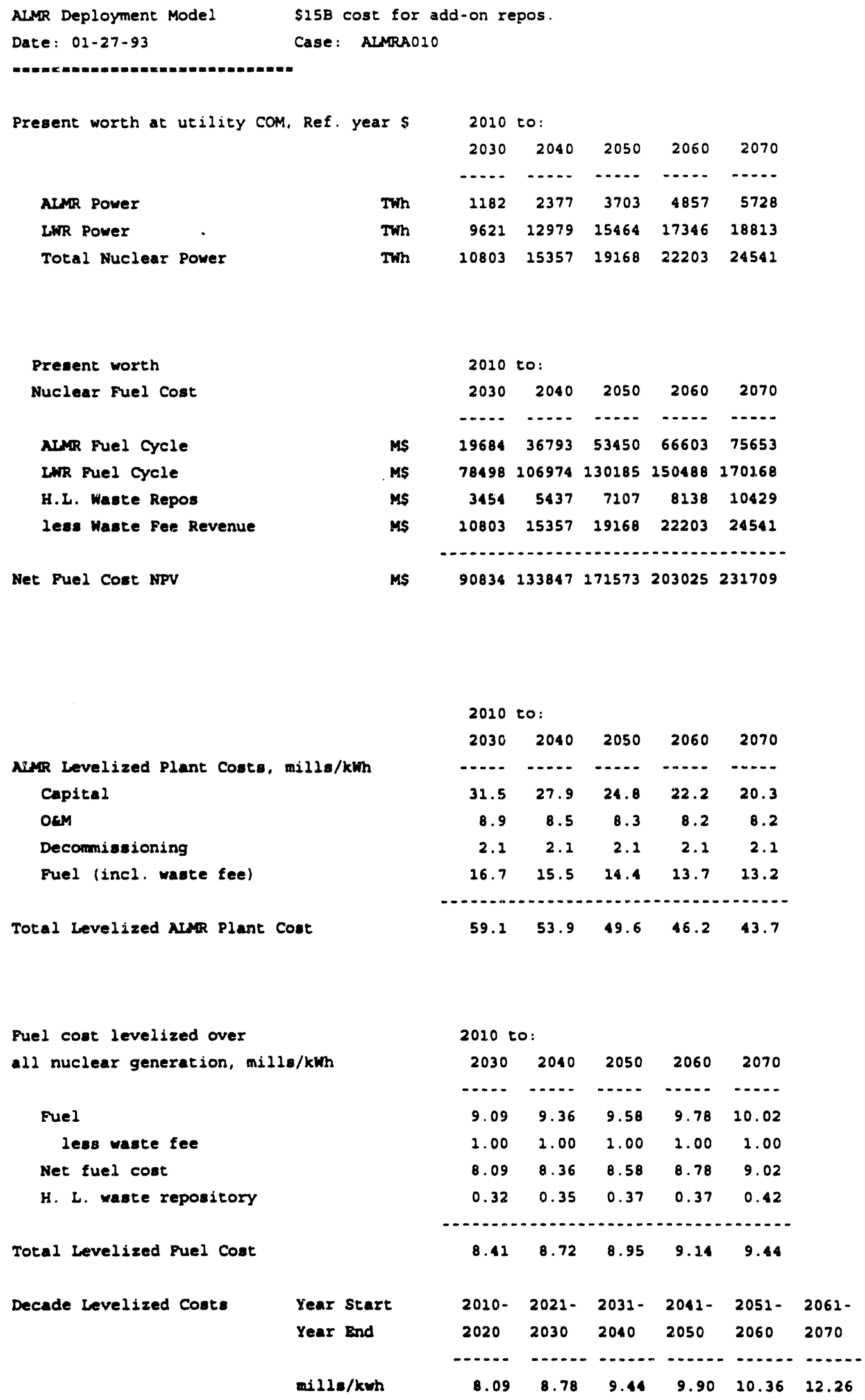




\section{Table 32}

\begin{tabular}{|c|c|c|c|c|c|c|c|}
\hline $\begin{array}{l}\text { ALMR Deployment Model } \\
\text { Date: } 01-27-93\end{array}$ & $\begin{array}{l}\text { AIMR } \\
\text { Case: }\end{array}$ & $\begin{array}{l}\text {. no ALMR } \\
\text { ALMR0010 }\end{array}$ & Case St & $\begin{array}{l}\text { UTmary } \\
\text { ALMRA01 }\end{array}$ & & & \\
\hline Present worth & & & 2010 & to: & & & \\
\hline Nuclear Fuel Cost & & & 2030 & 2040 & 2050 & 2060 & 2070 \\
\hline & & & $\cdots+$ & $\cdots$ & $\cdots$ & $\cdots$ & $\cdots+$ \\
\hline ALMR Fuel Cycle & & MS & -19684 & -36793 & -53450 & -66603 & -75653 \\
\hline LWR Fuel Cycle & & MS & 9859 & 21197 & 37437 & 58689 & 81006 \\
\hline H.t. Waste Repos & & MS & 9499 & 14666 & 17588 & 19583 & 18171 \\
\hline Iess Waste Fee Revenue & & MS & -0 & 0 & 0 & 0 & 0 \\
\hline Fuel Cost NPV & & MS & -326 & -931 & 1576 & 11670 & 23525 \\
\hline
\end{tabular}

Fuel cost levelized over

all nuclear generation, mills/kwh

2010 to:

$\begin{array}{lllll}2030 & 2040 & 2050 & 2060 & 2070\end{array}$

[...

Fuel

less waste fee

Net fuel cost

$\begin{array}{llllll}-0.91 & -1.02 & -0.84 & -0.36 & 0.22\end{array}$

$\begin{array}{lllll}-0.00 & 0.00 & 0.00 & 0.00 & 0.00\end{array}$

$\begin{array}{llllll}-0.91 & -1.02 & -0.84 & -0.36 & 0.22\end{array}$

H. I. waste repository

$\begin{array}{lllll}0.88 & 0.96 & 0.92 & 0.88 & 0.74\end{array}$

Total Levelized Fuel Cost

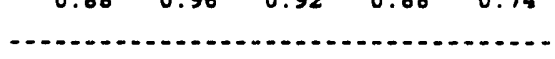

Decade Levelized Costs

Year Start

$\begin{array}{lllll}-0.03 & -0.06 & 0.08 & 0.53 & 0.96\end{array}$

Year End

2010- 2021- 2031- 2041- 2051- 2061-

$\begin{array}{llllll}2020 & 2030 & 2040 & 2050 & 2060 & 2070\end{array}$

$m i l l s / k w h$

$\begin{array}{cccccc}-0.32 & 0.31 & -0.13 & 0.66 & 3.33 & 5.07\end{array}$



$\begin{array}{ll}\text { ALMR Deployment Model } & \text { Base Case with reprocessing in repository costs } \\ \text { Date: } 02-03-93 & \text { Case: ALMRA014 }\end{array}$

Date: $02-03-93$

Present worth at utility Com, Ref. year $\$ 2010$ to:

$\begin{array}{lrrrrr} & 2030 & 2040 & 2050 & 2060 & 2070 \\ & \ldots \ldots & \ldots \ldots- & \ldots \ldots & \ldots \ldots & -\ldots .- \\ \text { TWh } & 1182 & 2377 & 3703 & 4857 & 5728 \\ \text { TWh } & 9621 & 12979 & 15464 & 17346 & 18813 \\ & 10803 & 15357 & 19168 & 22203 & 24541\end{array}$

\author{
Present worth \\ Nuclear Fuel Cost \\ ALM Fuel Cycle \\ IWR Fuel cycle \\ H.L. Waste Repos \\ less Waste Fee Revenue
}

Net Fued Cost NPV

\begin{tabular}{lrrrrr}
\multicolumn{8}{c}{2010 to: } & & & & \\
& 2030 & 2040 & 2050 & 2060 & 2070 \\
MS & 8724 & 17313 & 27267 & 36290 & 43145 \\
MS & 78498 & 106974 & 130185 & 150488 & 170168 \\
MS & 15834 & 24167 & 30524 & 33948 & 36803 \\
MS & 10803 & 15357 & 19168 & 22203 & 24541 \\
& $\ldots$ & $\ldots \ldots$ & $\ldots \ldots$ & $\ldots \ldots$ & $\ldots \ldots$ \\
MS & 92253 & 133097 & 168808 & 198523 & 225575
\end{tabular}

2010 to:

\begin{tabular}{|c|c|c|c|c|}
\hline 2030 & 2040 & 2050 & 2060 & 2070 \\
\hline 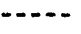 & $-\cdots$ & $-\cdots-$ & $\cdots$ & $\cdots$ \\
\hline 31.5 & 27.9 & 24.8 & 22.2 & 20.3 \\
\hline 8.9 & 8.5 & 8.3 & 8.2 & 8.2 \\
\hline 2.1 & 2.1 & 2.1 & 2.1 & 2.1 \\
\hline 7.4 & 7.3 & 7.4 & 7.5 & 7.5 \\
\hline
\end{tabular}

Total Levelized ALMR Plant Cost

Fuel cost levelized over all nuclear generation, mills/kwh

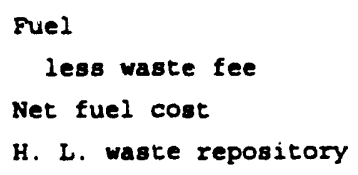


Table 34

\begin{tabular}{|c|c|c|c|c|c|c|c|c|}
\hline $\begin{array}{l}\text { ALMR Deployment Model } \\
\text { Date: } 01-27-93\end{array}$ & $\begin{array}{l}\text { ALMR } \\
\text { Case : }\end{array}$ & $\begin{array}{l}\text { v. nO ALMR } \\
: \quad \text { ALMRO0000 }\end{array}$ & $\begin{array}{l}\text { R Case St } \\
0\end{array}$ & $\begin{array}{l}\text { Summary } \\
\text { ALMRAO }\end{array}$ & & & & \\
\hline \multicolumn{9}{|l|}{ 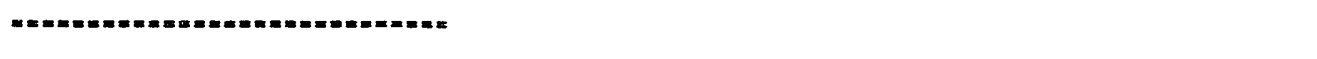 } \\
\hline Present worth & & & 2010 & o to: & & & & \\
\hline \multirow{2}{*}{ Nuclear Fued cost } & & & 2030 & 2040 & 2050 & 2060 & 2070 & \\
\hline & & & $\ldots$ & - $\cdots$. & $\ldots$ & $\cdots$ & $\cdots$ & \\
\hline ALMR Fuel Cycle & & M\$ & -8724 & -17313 & -27267 & -36290 & -43145 & \\
\hline LWR Fuel cycle & & MS & 9859 & 21197 & 37437 & 58689 & 81006 & \\
\hline H.L. Waste Repos & & MS & -6205 & -9561 & -12684 & -13968 & -15944 & \\
\hline less Waste Fee Revenue & & MS & -0 & 0 & 0 & 0 & 0 & \\
\hline Net Fuel Cost NPV & & MS & -5071 & -5677 & -2514 & 8430 & 21917 & \\
\hline \multicolumn{3}{|c|}{ Fuel cost levelized over } & $2010 t$ & to: & & & & \\
\hline \multirow{2}{*}{\multicolumn{3}{|c|}{ all nuclear generation, $\mathrm{mills} / \mathrm{kWh}$}} & 2030 & 2040 & 2050 & 2060 & 2070 & \\
\hline & & & $\cdots$ & ..... & $\cdots$ & $\cdots$ & $\ldots$. & \\
\hline \multicolumn{3}{|l|}{ Fuel } & 0.11 & 0.25 & 0.53 & 1.01 & 1.54 & \\
\hline \multicolumn{3}{|l|}{ less waste fee } & -0.00 & 0.00 & 0.00 & 0.00 & 0.00 & \\
\hline \multicolumn{3}{|l|}{ Net fuel cost } & 0.11 & 0.25 & 0.53 & 1.01 & 1.54 & \\
\hline \multicolumn{3}{|l|}{ H. L. waste repository } & -0.57 & -0.62 & -0.66 & -0.63 & -0.65 & \\
\hline Total Levelized Fuel Cost & & & -0.47 & -0.37 & -0.13 & 0.38 & 0.89 & \\
\hline \multirow[t]{4}{*}{ Decade Levelized Costs } & Year & Start & $2010-$ & $2021-$ & $2031-$ & $2041-$ & $2051-$ & $2061-$ \\
\hline & Year & End & 2020 & 2030 & 2040 & 2050 & 2060 & 2070 \\
\hline & & & $\cdots$ & -...-- & ........ & - & ......... & \\
\hline & mills & $3 /$ kwh & -0.58 & -0.34 & -0.23 & 0.83 & 3.61 & 5.77 \\
\hline
\end{tabular}


Table 35

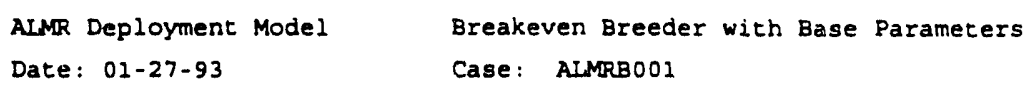

$\begin{array}{lrrrrr} & 2030 & 2040 & 2050 & 2060 & 2070 \\ & \ldots . . & \ldots \ldots . & \ldots \ldots & \ldots . . & \ldots . . \\ \text { TWh } & 1182 & 2287 & 3452 & 4473 & 5311 \\ \text { TWh } & 9621 & 13069 & 15715 & 17729 & 19231 \\ \text { TWh } & 10803 & 15357 & 19168 & 22203 & 24541\end{array}$

\begin{tabular}{lrrrrrr}
\multicolumn{8}{c}{2010 to: } & & & \\
& 2030 & 2040 & 2050 & 2060 & 2070 \\
MS & 21425 & 36778 & 49681 & 59440 & 66762 \\
MS & 78498 & 107766 & 132656 & 154881 & 175609 \\
MS & 4206 & 6273 & 7716 & 8685 & 10121 \\
MS & 10803 & 15357 & 19168 & 22203 & 24541 \\
& $\ldots \ldots . \ldots$ & $\ldots \ldots . \ldots$ & $\ldots \ldots$ & $\ldots \ldots$ \\
MS & 93326 & 135461 & 170886 & 200803 & 227950
\end{tabular}

ALMR Levelized Plant Costs, mills/kWh Capital

OCM

Decommissioning

Fuel (incl. waste fee).

Total Levelized ALMR Plant Cost

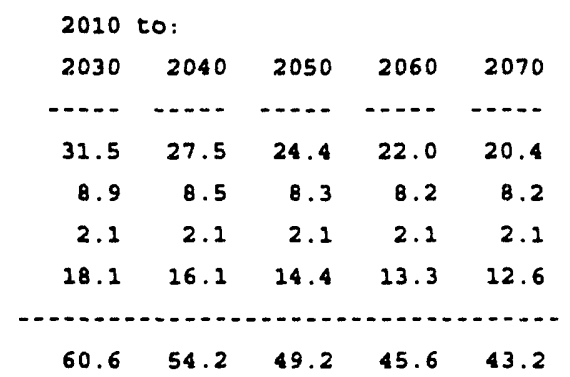

Puel cost levelized over

all nuclear generation, mills/ $\mathrm{kWh}$

$$
\text { Fuel }
$$

less waste fee

Net fuel cost

H. L. waste repository

Total Levelized Fuel cost

Decade Levelized Costa

\begin{tabular}{|c|c|c|c|c|c|c|}
\hline \multirow[t]{8}{*}{ s/kWh } & 2030 & 2040 & 2050 & 2060 & 2070 & \\
\hline & $\ldots$. & $\cdots$ & $\cdots$ & $\cdots$ & $\cdots$ & \\
\hline & 9.25 & 9.41 & 9.51 & 9.65 & 9.88 & \\
\hline & 1.00 & 2.00 & 1.00 & 1.00 & 1.00 & \\
\hline & 8.25 & 8.41 & 8.51 & 8.65 & 8.88 & \\
\hline & 0.39 & $0.4 i$ & 0.40 & 0.39 & 0.41 & \\
\hline & . & - n...... & . & $\cdots$ & - & \\
\hline & 8.64 & 8.82 & 8.92 & 9.04 & 9.29 & \\
\hline Year start & $2010-$ & $2021-$ & $2031-$ & $2041-$ & $2051-$ & $2061-$ \\
\hline ar End & 2020 & 2030 & 2040 & 2050 & 2060 & 2070 \\
\hline & $\cdots$ & -..... & -...... & -....... & 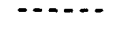 & ........ \\
\hline $1128 / \mathrm{kwh}$ & 8.32 & 9.02 & 9.25 & 9.30 & 9.86 & 21.61 \\
\hline
\end{tabular}


Table 36

\begin{tabular}{|c|c|c|c|c|c|c|c|}
\hline $\begin{array}{l}\text { ALMR Deployment Model } \\
\text { Date: } 01-27-93\end{array}$ & $\begin{array}{l}\text { ALMR } \\
\text { Case : }\end{array}$ & $\begin{array}{l}\text { nO ALMR } \\
\text { ALMRO0000 }\end{array}$ & $\begin{array}{c}\text { Case su } \\
-\end{array}$ & $\begin{array}{l}\text { Ummary } \\
\text { ALMRBOO }\end{array}$ & & & \\
\hline Present worth & & & 2010 & to: & & & \\
\hline Nuclear Fuel Cost & & & 2030 & 2040 & 2050 & 2060 & 2070 \\
\hline & & & ..... & $\cdots$ & $\cdots$ & $\cdots$ & $\cdots$ \\
\hline ALMR Fuel cycle & & MS & -21425 & -36778 & -49681 & -59440 & -66762 \\
\hline LWR Fuel Cycle & & MS & 9859 & 20404 & 34966 & 54296 & 75566 \\
\hline H.L. Waste Repos & & MS & 5423 & 8333 & 10124 & 11295 & 10738 \\
\hline less Waste Fee Revenue & & MS & -0 & 0 & 0 & 0 & 0 \\
\hline Net Fuel Cost NPV & & MS & -6143 & -8041 & -4591 & 6151 & 19542 \\
\hline
\end{tabular}

Fued cost levelized over

all nuclear generation, mills/kwh

2010 to:

$\begin{array}{lllll}2030 & 2040 \quad 2050 \quad 2060 \quad 2070\end{array}$

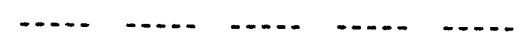

Fue1

less waste fee

$\begin{array}{lllll}-1.07 & -1.07 & -0.77 & -0.23 & 0.36\end{array}$

$\begin{array}{lllll}-0.00 & 0.00 & 0.00 & 0.00 & 0.00\end{array}$

Net fuel cost

$\begin{array}{llllll}-1.07 & -1.07 & -0.77 & -0.23 & 0.36\end{array}$

H. L. waste repository

$\begin{array}{lllll}0.50 & 0.54 & 0.53 & 0.51 & 0.44\end{array}$

Total Levelized Fuel Cost

$\begin{array}{llllll}-0.57 & -0.52 & -0.24 & 0.28 & 0.80\end{array}$

Decade Levelized Costs

Year Start

2010- 2021- 2031- 2041- 2051- 2061-

Year End

$\begin{array}{llllll}2020 & 2030 & 2040 & 2050 & 2060 & 2070\end{array}$

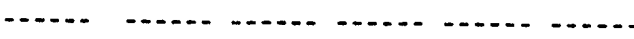

$\mathrm{mills} / \mathrm{kwh}$

$\begin{array}{llllll}-0.55 & -0.59 & -0.42 & 0.91 & 3.54 & 5.73\end{array}$ 


\section{MAXMMUM DEPLOYMENT OF BREAKEVEN PLANT}

This case utilizes the same fuel cycle as the previous case but the deployment by 2030 was increased to the maximum possible number of ALMR plants that can be deployed by this date. This deployment is limited only by the amount of fissile material available for starting up and sustaining the ALMR plants. This leads to $51 \mathrm{GWe}$ of ALMR capacity in 2030 as compared to $27 \mathrm{GWe}$ in the constrained ALMR breakeven case described in Sect. 2.13. The additional ALMR generation is fueled by the more rapid recovery of actinides from LWR spent fuel. As shown in the cost summaries (Tables 37 and 38), the increased utilization and advanced timing of ALMRs increases the relative economics of this case compared to the case in Sect. 2.13 by about $\$ 4.1$ billion.

\section{BASE ALMR BREEDER}

A second alternate reactor fuel cycle was considered in addition to the base ALMR breakeven case. In this case a fuel cycle with a breeding ratio of 1.24 was considered for the ALMR. A comparison of this fuel cycle with the base case was given in Tables 8 and 9. All other cost factors were unchanged from the base burner case (Sect. 2.2). The annual energy generation for this case is shown in Fig. 9. The uranium ore use and price for LWR plants are presented in Fig. 10. As a result of the deployment of the breeder ALMRs, the demand for uranium is less than that for the burner case depicted in Fig. 7. This is because the burner deployment was limited by the availability of spent LWR fuel whereas the breeder creates an excess amount of fuel which can be used to start-up other ALMRs. The waste repository loadings are shown in Fig. 11 and are similar to that for the burner case.

The cost summaries for this case (Tables 39 and 40) indicate a NPV of over $\$ 41$ billion for the 2010 to 2070 period compared to the no ALMR case. This is a substantial improvement resulting in nearly $\$ 25$ billion more savings than for the ALMR base case burner.

\section{BREEDER PLANT WITH DEFENSE Pu}

This case uses the same data as the ALMR Base Case Breeder discussed in the previous section except that $100 \mathrm{MT}$ of defense-related plutonium is assumed to be made available to the ALMR system at no cost for the fissile material. The energy generation, uranium demands, and repository requirements are nearly identical to those shown in Figs. 9-11. The cost summaries are given in Tables 41 and 42. As shown in Table 42, there is an increased economic benefit of ALMRs relative to the no ALMR case due to the availability of no cost fissile material and the resulting delay in the need for LWR reprocessing. The differential NPV between this case and the null (no ALMR) case is \$48.1 billion over the period 2010-2070 or about \$25 billion more than the differential for the base case burner given in Sect. 2.3 .

\section{MAXIMUM DEPLOYMENT OF BREEDER PLANT}

This case utilizes the same fuel cycle as the previous case but the deployment by 2030 was increased to the maximum possible number of ALMR plants that can be deployed by this date. This deployment is limited only by the amount of fissile material available for starting up the ALMR plants. This leads to $80 \mathrm{GWe}$ of ALMR capacity in 2030 as compared to $27 \mathrm{GWe}$ in the constrained 
case described in Sect. 2.15. The additional ALMR generation is fueled by the more rapid recovery of actinides from LWR spent fuel and from the quantity of excess fissile material produced by the breeder. The annual energy generation estimated for this case is shown in Fig. 12. The uranium ore use and price for LWR plants are presented in Fig. 13. The equivalent heavy metal disposed of in the repository is shown in Fig. 14. While there are differences in the year-by-year values between these three figures and the comparable ones in Sect. 2.15, the long term year 2070 values for the ALMR power production, uranium use and price, and waste repository loadings are nearly the same here as found in Sect. 2.15.

The cost summaries for this case (Tables 43 and 44) indicate a greater improvement over the base case burner (Tables 12 and 13) than found in the slower deployment case. The results indicate a NPV advantage for this case compared to the no ALMR case of \$46.8 billion over the 2010-2070 period. This is $\$ 5.4$ billion more than for the ALMR base case breeder.

\subsection{NO UTILZATION OF INITAL LWR SPENT FUEL STOCKS}

All the previous ALMR cases have assumed that all $L W R$ spent fuel is processed to recover the useful fissile materials as fuel for ALMR power plants. This case addresses the scenario in which the total amount of LWR spent fuel accumulated as of the inception of ALMR commercial deployment (i.e., 60,000 MTHM in the year 2010) is not processed to recover the actinides but rather is disposed intact in the first repository, starting in 2010. Only LWR spent fuel generated in 2010 and beyond is assumed to be processed for actinide recovery. As shown in Fig. 15, a second repository will be required by 2035 with a third repository needed by 2070 . This compares to a third repository requirement by 2040 for the null case with no ALMR deployment. The cost summaries for this case are given in Tables $\mathbf{4 5}$ and $\mathbf{4 6}$. The outcome of this scenario is influenced by the initial lack of fissile material for ALMR startups. Not utilizing the accumulated LWR spent fuel limits the number of ALMR plants that can be deployed. As a result, more nuclear energy is obtained from uranium burning plants, thereby increasing the demand and therefore cost of the uranium-burner fuel cycle. In addition, the assumed intact disposal of spent fuel assemblies requires an earlier second repository and is more costly than the disposal of process waste assumed in the ALMR base burner case of Sect. 2.2. The resulting ALMR NPV benefit relative to the null (no-ALMR) case is $\$ 12.5$ billion, which is $\$ 4.1$ billion less than the ALMR burner case utilizing all available LWR spent fuel. 
Table 37

ALMR Deployment Model

Date: $02-03-93$
Base case Breakeven Breeder with Maximum Deployment Case: ALMRBO03

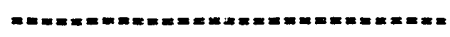

Present worth at utility COM, Ref. year $\$$

ALMR Power

LWR Power

Total Nuclear Power

\begin{tabular}{rrrrr}
2010 & to: & & & \\
2030 & 2040 & 2050 & 2060 & 2070 \\
\hdashline & $\ldots \ldots$ & $\ldots-$ & $\ldots .-$ & $\ldots$ \\
2026 & 3423 & 4614 & 5615 & 6438 \\
8776 & 11934 & 14554 & 16588 & 18103 \\
10803 & 15357 & 19168 & 22203 & 24541
\end{tabular}

2010 to:

$20302040 \quad 2050 \quad 2060 \quad 2070$

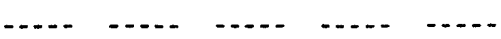

$\begin{array}{lllll}32789 & 48345 & 59896 & 68904 & 75947\end{array}$

$7147998036122060 \quad 143766 \quad 164049$

$\begin{array}{lllll}6461 & 7909 & 9004 & 9871 & 11301\end{array}$

$\begin{array}{llllll}10803 & 15357 & 19168 & 22203 & 24541\end{array}$

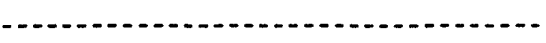

MS $\quad 99927 \quad 138933 \quad 171792 \quad 200337226754$

Net Fuel Cost NPV

ALMR Levelized Plant Costs, mills/kwh Capital

OCM

Decommissioning

Fuel (incl. waste fee)

Total Levelized AIMR Plant Cost

Fuel cost levelized over

all nuclear generation, mills/kWh

Fuel

less waste fee

Net fuel cost

H. I. waste repository

Total Levelized Fuel Cost

Decade Levelized Costs
Year Start

Year End

milis;kun
2010 to:

\begin{tabular}{rrrrr}
2030 & 2040 & 2050 & 2060 & 2070 \\
31.2 & 26.0 & 22.8 & 20.9 & 19.6 \\
8.6 & 8.4 & 8.3 & 8.2 & 8.2 \\
2.1 & 2.1 & 2.1 & 2.1 & 2.1 \\
16.2 & 14.1 & 13.0 & 12.3 & 11.8 \\
\hline 58.0 & 50.6 & 46.2 & 43.4 & 41.6
\end{tabular}

2010 to:

\begin{tabular}{ccccc}
2030 & 2040 & 2050 & 2060 & 2070 \\
$\ldots .$. & $\ldots .$. & $\ldots \ldots$ & $\ldots \ldots$ & $\ldots .$. \\
9.65 & 9.53 & 9.49 & 9.58 & 9.78 \\
1.00 & 1.00 & 1.00 & 1.00 & 1.00 \\
8.65 & 8.53 & 8.49 & 8.58 & 8.78 \\
0.60 & 0.52 & 0.47 & 0.44 & 0.46 \\
\hline .25 & 9.05 & 8.96 & 9.02 & 9.24
\end{tabular}

2010- 2021-2031-2041-2051-2061-

$\begin{array}{llllll}2020 & 2030 \quad 2040 \quad 2050 \quad 2060 \quad 2070\end{array}$

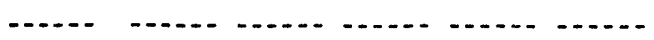

$\begin{array}{llllll}8.85 & 9.72 & 8.56 & 8.62 & 9.40 & 11.30\end{array}$ 
Table 38

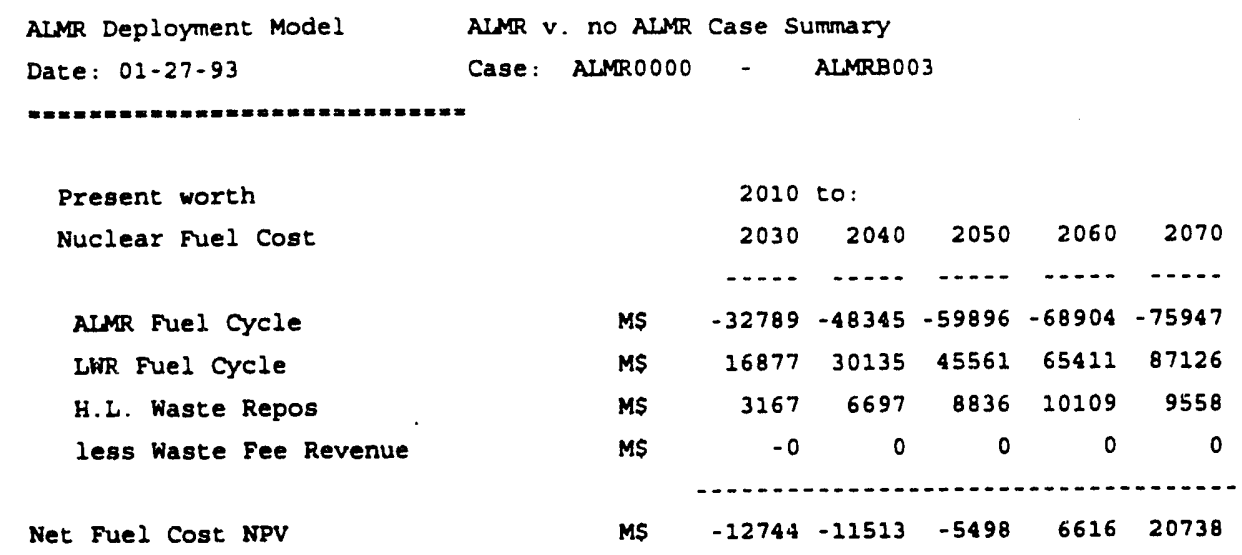

Fuel cost levelized over

all nuclear generation, mills/kwh

2010 to:

$20302040 \quad 2050 \quad 20602070$

Fuel

less waste fee

Net fuel cost

H. L. waste repository

Total Levelized Fuel Cost

[...

$\begin{array}{llllll}-1.47 & -1.19 & -0.75 & -0.16 & 0.46\end{array}$

$\begin{array}{llllll}-0.00 & 0.00 & 0.00 & 0.00 & 0.00\end{array}$

$\begin{array}{lllll}-1.47 & -1.19 & -0.75 & -0.16 & 0.46\end{array}$

$\begin{array}{lllll}0.29 & 0.44 & 0.46 & 0.46 & 0.39\end{array}$

$\begin{array}{lllll}-1.18 & -0.75 & -0.29 & 0.30 & 0.85\end{array}$

Decade Levelized Costs

\begin{tabular}{|c|c|c|c|c|c|c|}
\hline $\begin{array}{l}\text { Year Start } \\
\text { Year End }\end{array}$ & $\begin{array}{l}2010- \\
2020\end{array}$ & $\begin{array}{l}2021- \\
2030\end{array}$ & $\begin{array}{l}2031= \\
2040\end{array}$ & $\begin{array}{l}2041- \\
2050\end{array}$ & $\begin{array}{l}2051- \\
2060\end{array}$ & $\begin{array}{l}2061- \\
2070\end{array}$ \\
\hline & & & 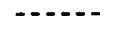 & $\cdots$ & $\cdots$ & \\
\hline mills/k & -1.08 & -1.29 & 0.27 & 1.58 & 3.99 & 6.04 \\
\hline
\end{tabular}




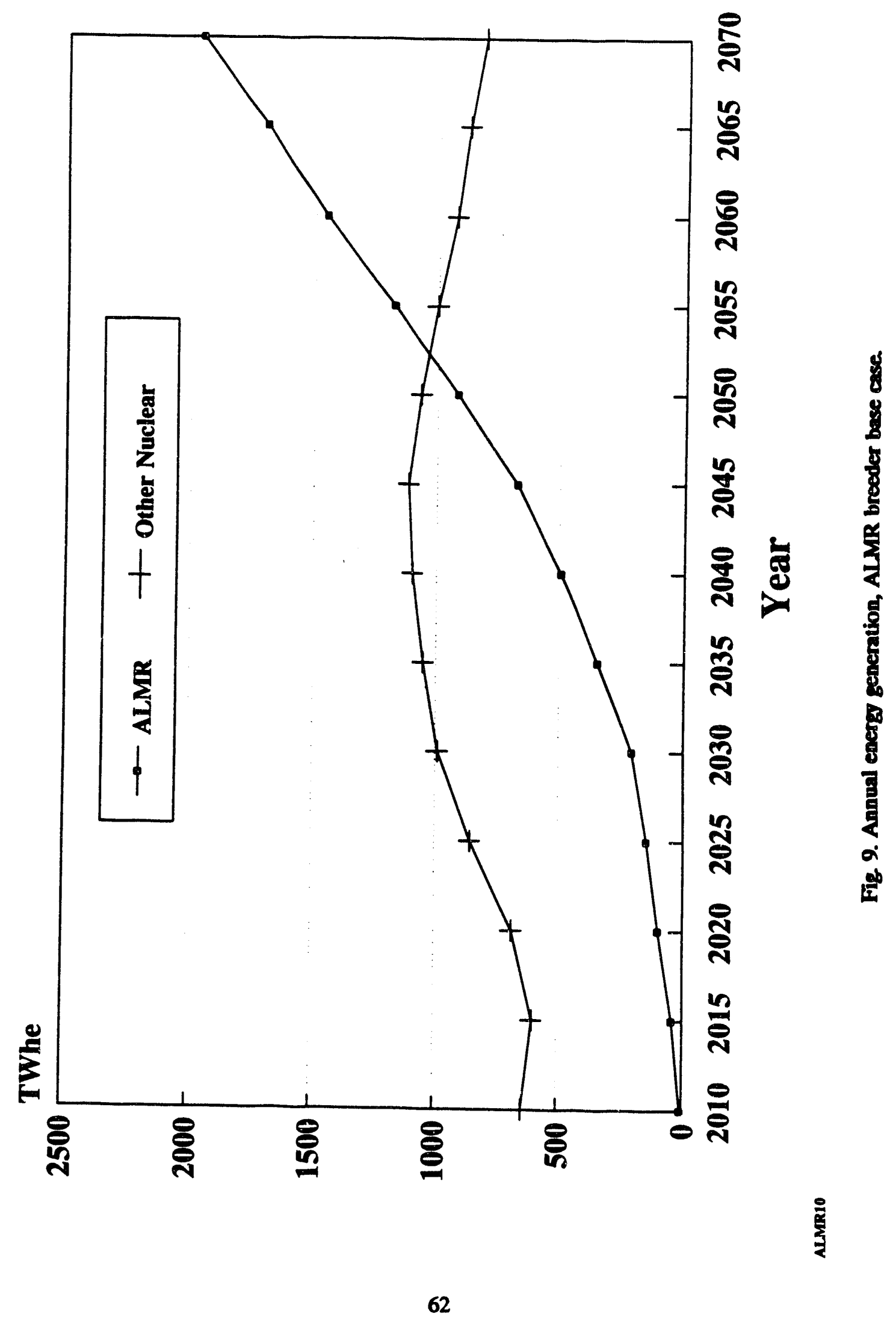




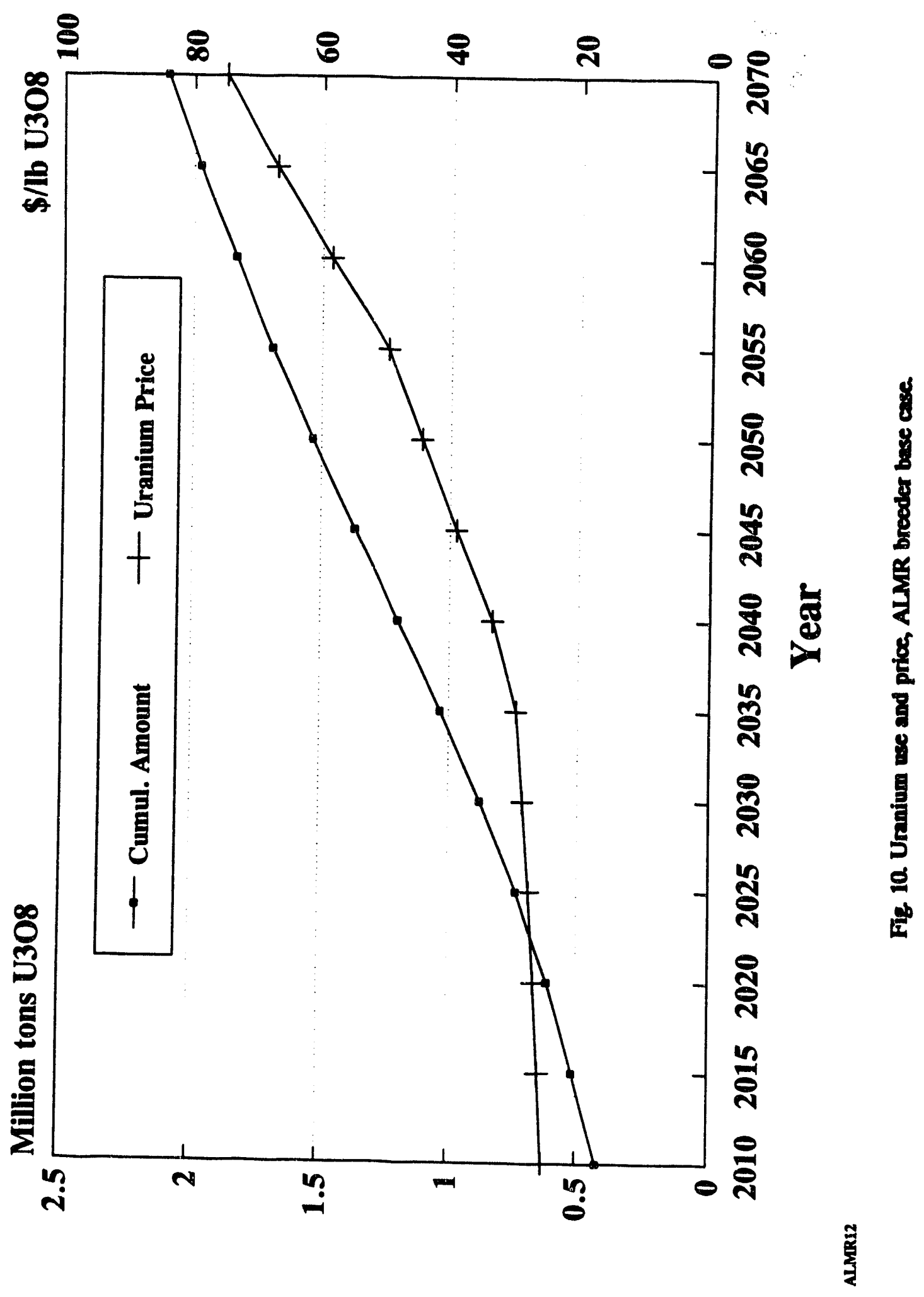




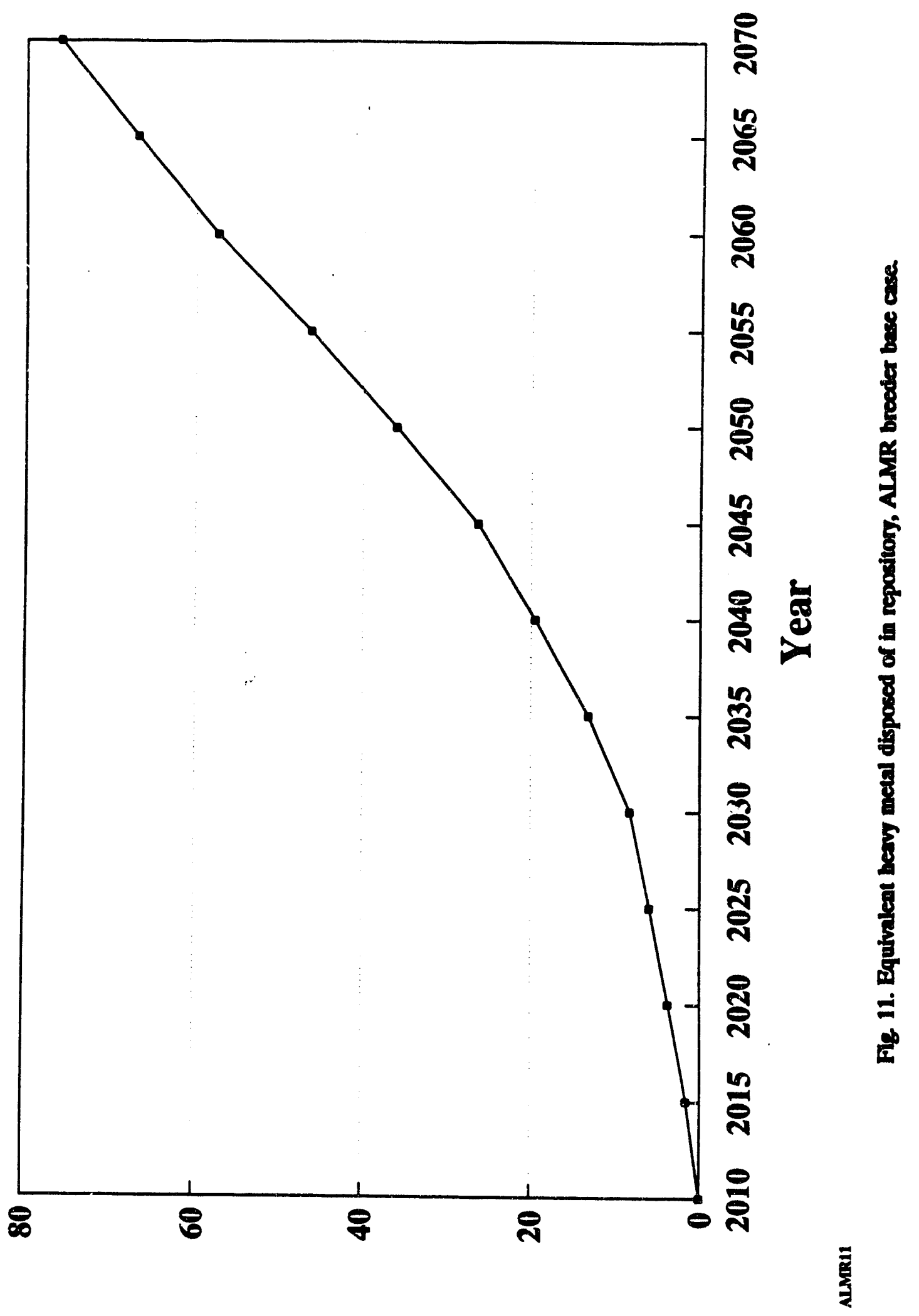




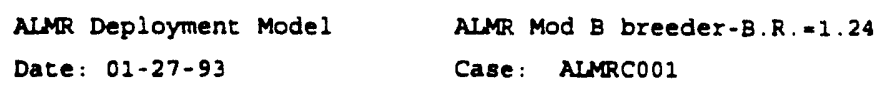

\begin{tabular}{|c|c|c|c|c|c|}
\hline & 2030 & 2040 & 2050 & 2060 & 2070 \\
\hline & $\ldots$ & $\ldots$ & -... & $\ldots$ & $\ldots$ \\
\hline MS & 15544 & 27989 & 41505 & 55798 & 67975 \\
\hline MS & 79260 & 108320 & 130220 & 144658 & 154088 \\
\hline MS & 2602 & 4227 & 5761 & 7076 & 8563 \\
\hline MS & 10803 & 15357 & 19168 & 22203 & 24541 \\
\hline MS & 86603 & 125178 & 158318 & 285328 & 206084 \\
\hline
\end{tabular}

ALR Levelized Plant Costs, millo/kWh Capital 
Table 40

\begin{tabular}{|c|c|c|c|c|c|c|c|c|}
\hline $\begin{array}{l}\text { ALMR Deployment Model } \\
\text { Date: } 01-27-93\end{array}$ & $\begin{array}{l}\text { ALMR } \\
\text { Case : }\end{array}$ & $\begin{array}{l}\text { v. no ALATR } \\
: \quad \text { ALMRO000 }\end{array}$ & $\begin{array}{l}\mathrm{R} \text { Case } \mathrm{s} \\
0\end{array}$ & $\begin{array}{l}\text { Summary } \\
\text { ALMRCOO }\end{array}$ & & & & \\
\hline \multicolumn{9}{|l|}{ 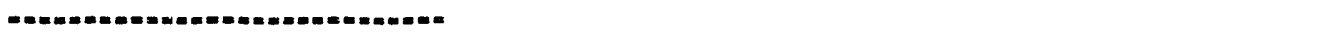 } \\
\hline \multirow{3}{*}{$\begin{array}{l}\text { Present worth } \\
\text { Nuclear Fuel Cost }\end{array}$} & & & 2010 & to: & & & & \\
\hline & & & 2030 & 2040 & 2050 & 2060 & 2070 & \\
\hline & & & $\ldots$ & $\ldots$ & $\ldots$ & -.... & $\ldots$ & \\
\hline ALAR Fuel Cycle & & MS & -15544 & -27989 & -41505 & -55798 & -67975 & \\
\hline LWR Fuel Cycle & & MS & 9097 & 19851 & 37402 & 64519 & 97087 & \\
\hline H.L. Waste Repos & & MS & 7027 & 10380 & 12080 & 12904 & 12295 & \\
\hline less Waste Fee Revenue & & MS & 0 & 0 & 0 & 0 & 0 & \\
\hline Net Fuel Cost NPV & & MS & 580 & 2241 & 7977 & 21625 & 41408 & \\
\hline \multicolumn{3}{|l|}{ Fuel cost levelized over } & 2010 & to: & & & & \\
\hline \multirow{2}{*}{\multicolumn{3}{|c|}{ all nuclear generation, mills $/ \mathrm{kmh}$}} & 2030 & 2040 & 2050 & 2060 & 2070 & \\
\hline & & & $\ldots$ & $\ldots$ & $\ldots$ & $\ldots$ & $\ldots$ & \\
\hline \multicolumn{3}{|l|}{ Fuel } & -0.60 & -0.53 & -0.21 & 0.39 & 2.19 & \\
\hline \multicolumn{3}{|l|}{ less waste fee } & 0.00 & 0.00 & 0.00 & 0.00 & 0.00 & \\
\hline \multicolumn{3}{|l|}{ Net fuel cost } & -0.60 & -0.53 & -0.21 & 0.39 & 1.19 & \\
\hline \multicolumn{3}{|l|}{ H. L. waste repository } & 0.65 & 0.68 & 0.63 & 0.58 & 0.50 & \\
\hline Total Levelized Fuel Cost & & & 0.05 & 0.25 & 0.12 & 0.97 & 1.69 & \\
\hline \multirow[t]{3}{*}{ Decade Levelized Costs } & $\begin{array}{l}\text { Year } \\
\text { Year }\end{array}$ & $\begin{array}{l}\text { Start } \\
\text { End }\end{array}$ & $\begin{array}{l}2010- \\
2020\end{array}$ & $\begin{array}{l}2021- \\
2030\end{array}$ & $\begin{array}{l}2031- \\
2040\end{array}$ & $\begin{array}{l}2041- \\
2050\end{array}$ & $\begin{array}{l}2051- \\
2060\end{array}$ & $\begin{array}{l}2061- \\
2070\end{array}$ \\
\hline & & & $\ldots .$. & ........ & $\ldots$ & $\ldots$ & n....... & $\cdots$ \\
\hline & mills & s/kwh & -0.04 & 0.17 & 0.36 & 1.50 & 4.50 & 8.46 \\
\hline
\end{tabular}




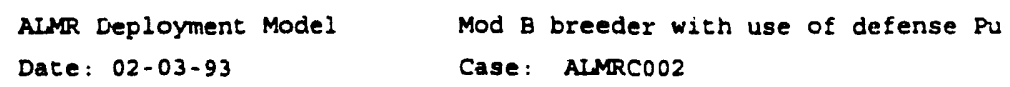

Present worth

Nuclear Fuel Cost

ALAR Fuel cycle

LWR Fuel Cycle

H.I. Waste Repos

less Waste Fee Revenue

Net Fuel Cost NPV

\begin{tabular}{|c|c|c|c|c|c|}
\hline & 2030 & 2040 & 2050 & 2060 & 2070 \\
\hline & -.... & $\ldots$ & -.... & $\cdots$ & $\cdots$ \\
\hline$\$$ & 10357 & 24655 & 40780 & 56277 & 68691 \\
\hline MS & 79260 & 107066 & 126351 & 239077 & 247050 \\
\hline MS & 1821 & 3813 & 5563 & 6782 & 8194 \\
\hline MS & 10803 & 15357 & 19168 & 22203 & 24541 \\
\hline
\end{tabular}

ALMR Levelized Plant Costs, milla/kWh Capital

OSM

Decomissioning

Fuel (incl. waste fee)

Total Levelized ALMR Plant Cost

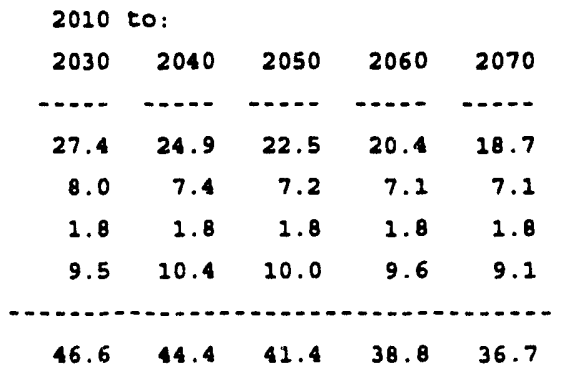

Fuel cost levelized over

all nuclear generation, mills/kwh

Fuel

less waste fee

Net fuel cost.

H. L. waste repository

Total Levelized Fuel Cost

2010 to:

$\begin{array}{lllll}2030 & 2040 & 2050^{\circ} 2060 \quad 2070\end{array}$

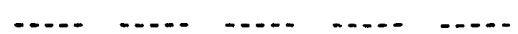

$\begin{array}{lllll}8.30 & 8.58 & 8.72 & 8.80 & 8.79\end{array}$

$\begin{array}{lllll}1.00 & 1.00 & 1.00 & 1.00 & 1.00\end{array}$

$\begin{array}{lllll}7.30 & 7.58 & 7.72 & 7.80 & 7.79\end{array}$

$\begin{array}{lllll}0.17 & 0.25 & 0.29 & 0.31 & 0.33\end{array}$

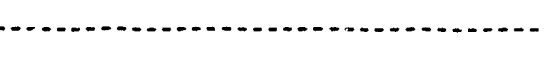

Decade Levelized Costs

Year Start

$\begin{array}{lllll}7.46 & 7.83 & 8.01 & 8.10 & 8.12\end{array}$

2010- 2021- 2031- 2041- 2051- 2061-

$\begin{array}{llllll}2020 & 2030 & 2040 & 2050 & 2060 & 2070\end{array}$

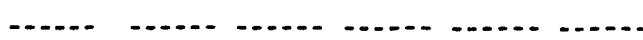

mills/kwh

$\begin{array}{llllll}7.02 & 7.98 & 8.68 & 8.75 & 8.70 & 8.32\end{array}$ 
Table 42

\begin{tabular}{|c|c|c|c|c|c|c|c|c|}
\hline $\begin{array}{l}\text { ALMR Deployment Model } \\
\text { Date: } 01-27-93\end{array}$ & $\begin{array}{l}\text { ALMR } \\
\text { Case : }\end{array}$ & $\begin{array}{l}\text { v. nO ALMR } \\
: \quad \text { ALMRO0000 }\end{array}$ & Case su & $\begin{array}{l}\text { Ummary } \\
\text { ALMRCOO }\end{array}$ & & & & \\
\hline \multicolumn{9}{|l|}{ 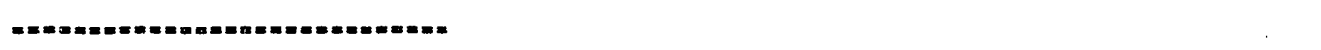 } \\
\hline Present worth & & & 2010 & to: & & & & \\
\hline \multirow[t]{2}{*}{ Nuclear Fuel Cost } & & & 2030 & 2040 & 2050 & 2060 & 2070 & \\
\hline & & & $-\ldots$ & $\ldots$ & $\ldots$ & -.... & -.... & \\
\hline ALMR Fuel cycle & & MS & -10357 & -24655 & -40780 & -56277 & -68691 & \\
\hline LWR Fuel cycle & & M\$ & 9097 & 21104 & 41271 & 70100 & 104125 & \\
\hline H.L. Waste Repos & & M\$ & 7808 & 10793 & 12277 & 13198 & 12665 & \\
\hline less Waste Fee Revenue & & MS & 0 & 0 & 0 & 0 & 0 & \\
\hline Net Fuel Cost NPV & & M\$ & 6548 & 7242 & 12767 & 27020 & 48099 & \\
\hline \multicolumn{3}{|l|}{ Fuel cost levelized over } & 2010 & to: & & & & \\
\hline \multirow{2}{*}{\multicolumn{3}{|c|}{ all nuclear generation, mills/kWh }} & 2030 & 2040 & 2050 & 2060 & 2070 & \\
\hline & & & $\ldots$ & $\ldots$ & $\ldots$ & $\ldots .$. & $\ldots .$. & \\
\hline \multicolumn{3}{|l|}{ Fuel } & -0.12 & -0.23 & 0.03 & 0.62 & 2.44 & \\
\hline \multicolumn{3}{|l|}{ less waste fee } & 0.00 & 0.00 & 0.00 & 0.00 & 0.00 & \\
\hline \multicolumn{3}{|l|}{ Net fuel cost } & -0.12 & -0.23 & 0.03 & 0.62 & 1.44 & \\
\hline \multicolumn{3}{|l|}{ H. L. waste repository } & 0.72 & 0.70 & 0.64 & 0.59 & 0.52 & \\
\hline Total Levelized Fuel Cost & & & 0.61 & 0.47 & 0.67 & 1.22 & 1.96 & \\
\hline \multirow[t]{3}{*}{ Decade Levelized Costs } & Year & Start & 2010- & 2021- & $2031-$ & 2041- & 2051- & $2061-$ \\
\hline & Year & End & 2020 & 2030 & 2040 & 2050 & 2060 & 2070 \\
\hline & mills & $8 /$ kwh & 0.75 & 0.44 & 0.15 & 1.45 & 4.70 & 9.01 \\
\hline
\end{tabular}




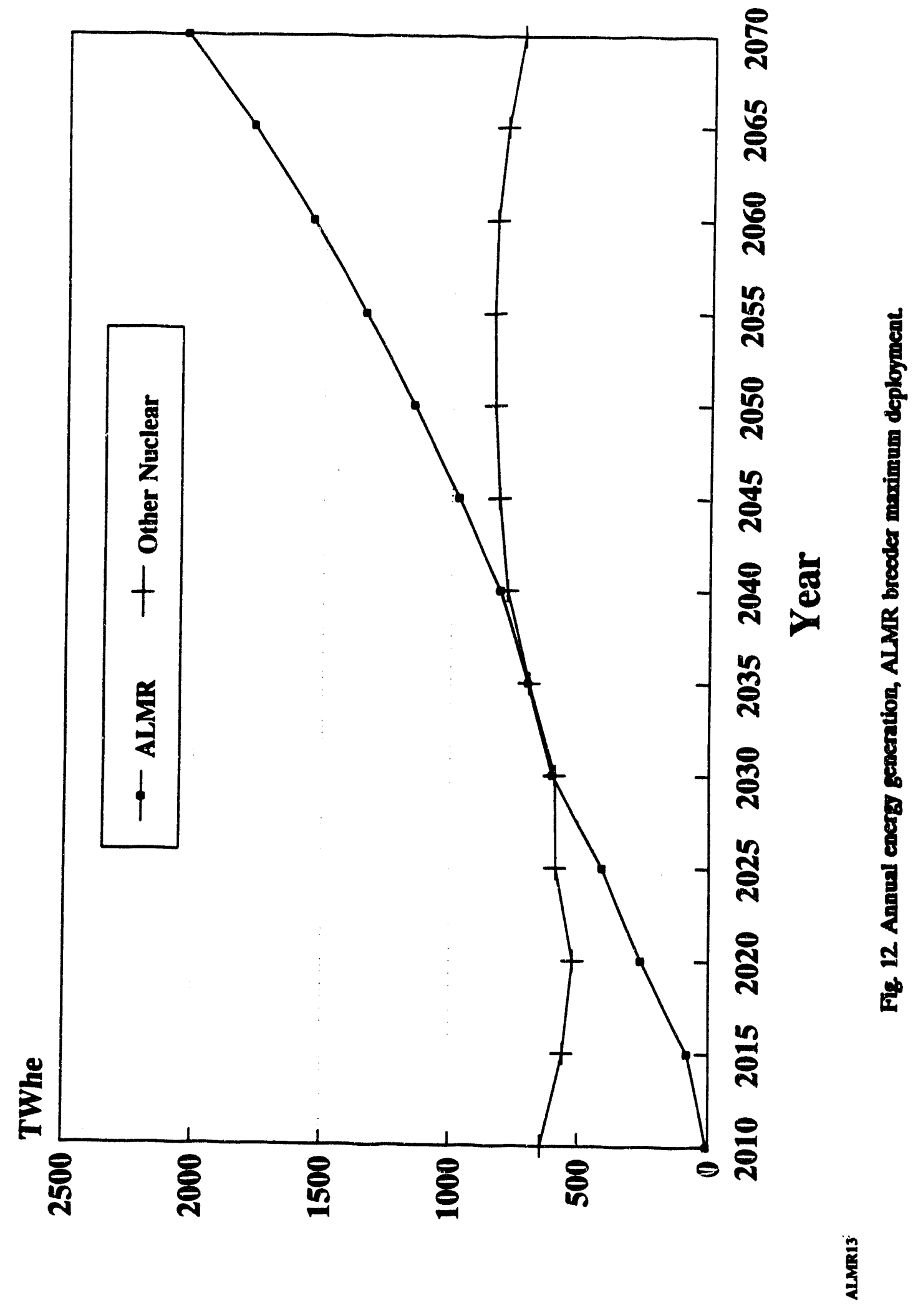




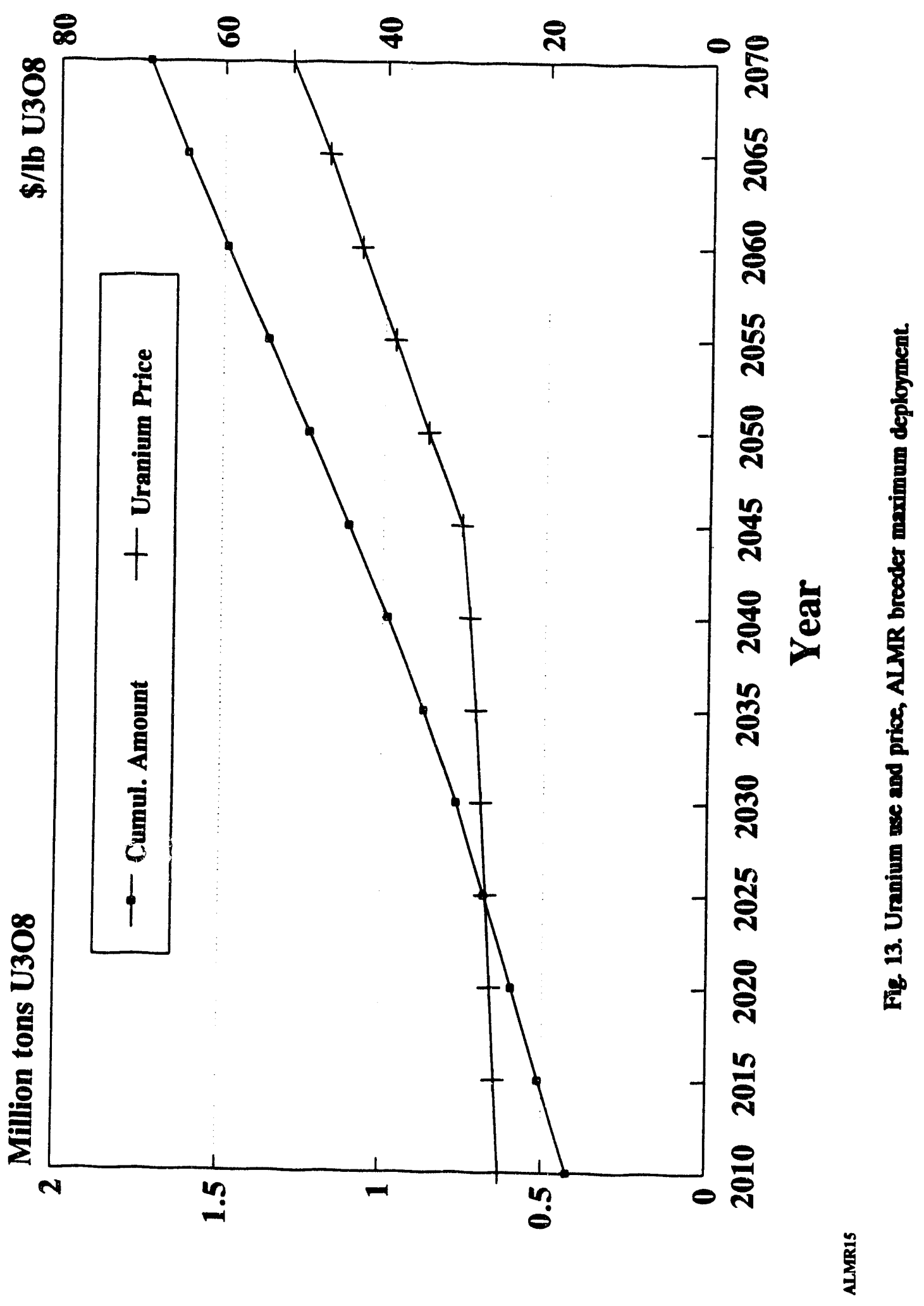




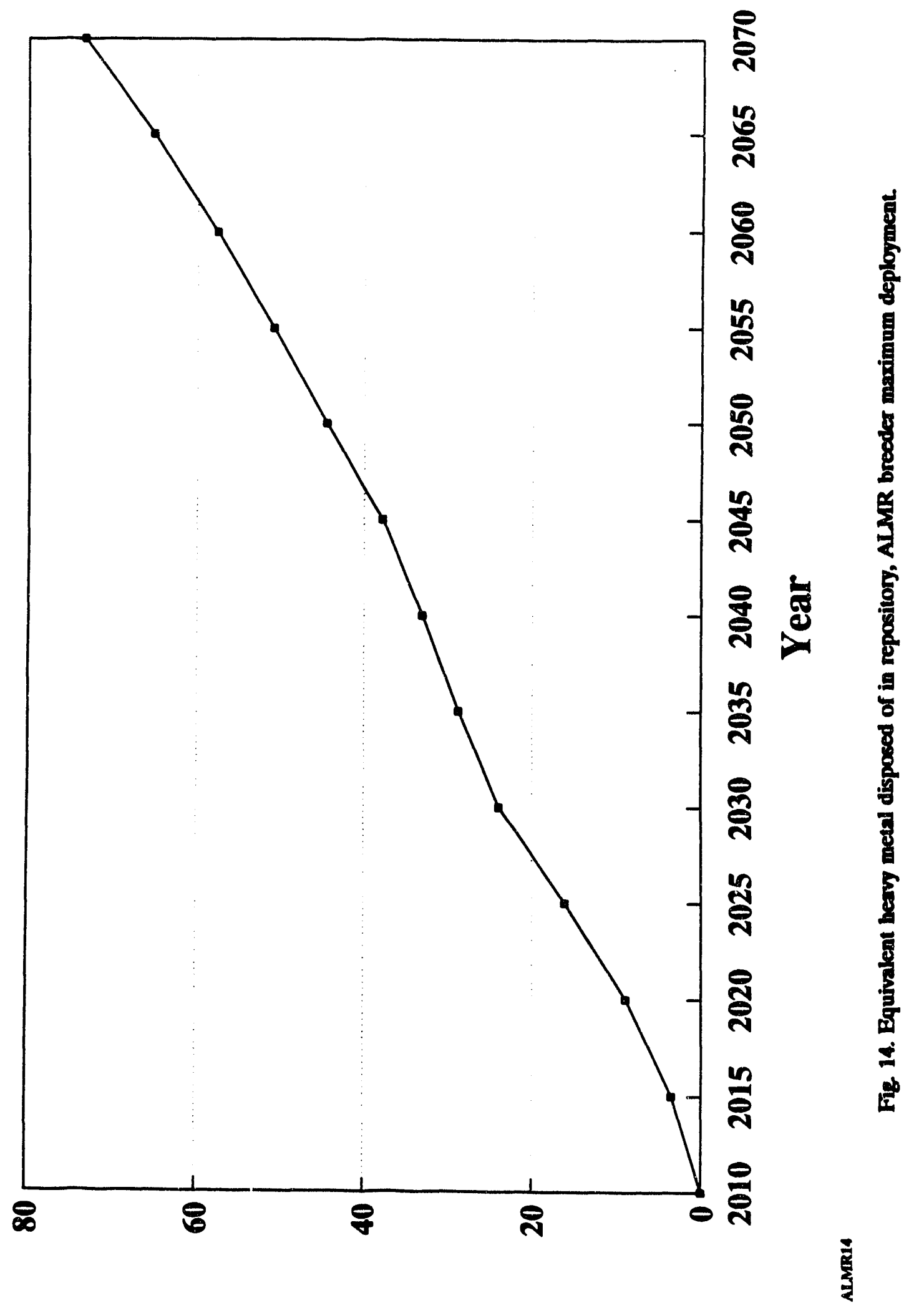


Table 43

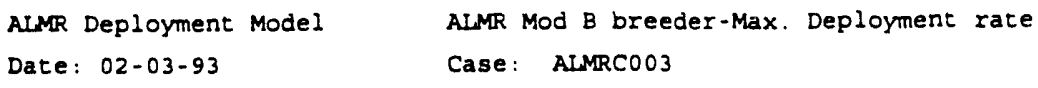

$\begin{array}{lrrrrr} & 2030 & 2040 & 2050 & 2060 & 2070 \\ & \ldots \ldots & \ldots \ldots & \ldots \ldots & \ldots \ldots . & \ldots \ldots \\ \text { TWh } & 2921 & 5201 & 7279 & 9151 & 10779 \\ \text { TWh } & 7882 & 10155 & 11888 & 13052 & 13763 \\ \text { TWh } & 10803 & 15357 & 19168 & 22203 & 24541\end{array}$

AIMR Levelized Plant Costs, mills/kWh Capital

\begin{tabular}{|c|c|c|c|c|c|}
\hline & 2030 & 2040 & 2050 & 2060 & 2070 \\
\hline & .... & $\ldots$ & $\cdots$ & $\cdots$ & - . \\
\hline MS & 36448 & 56689 & 72921 & 86699 & 98306 \\
\hline MS & 64069 & 83029 & 97911 & 108756 & 115934 \\
\hline MS & 6324 & 7712 & 8790 & 9608 & 10973 \\
\hline MS & 10803 & 15357 & 19168 & 2.2203 & 24541 \\
\hline
\end{tabular}

Fuel cost levelized over

all nuclear generation, millo/kWh

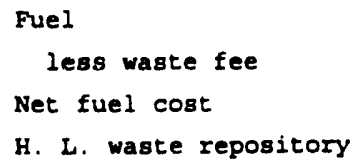


Table 44

\begin{tabular}{|c|c|c|c|c|c|c|}
\hline $\begin{array}{l}\text { ALMR Deployment Model } \\
\text { Date: } 01-27-93\end{array}$ & $\begin{array}{l}\text { ALMR v. no ALMR } \\
\text { Case : ALMRO0000 }\end{array}$ & Case su & $\begin{array}{l}\text { ummary } \\
\text { ALMRCOO }\end{array}$ & & & \\
\hline Present worth & & 2010 & to: & & & \\
\hline Nuclear Fuel Cost & & 2030 & 2040 & 2050 & 2060 & 2070 \\
\hline & & $\cdots$ & $\cdots$ & $\cdots$ & $\cdots$ & $\cdots$ \\
\hline ALMR Fuel Cycle & MS & -36448 & -56689 & -72921 & -86699 & -98306 \\
\hline LWR Fuel Cycle & M\$ & 24288 & 45141 & 69710 & 100421 & 135241 \\
\hline H.L. Waste Repos & MS & 3305 & 6894 & 9051 & 10372 & 9885 \\
\hline less Waste Fee Revenue & M\$ & -0 & 0 & 0 & 0 & 0 \\
\hline Net Fuel Cost NPV & MS & -8855 & -4654 & 5840 & 24094 & 46821 \\
\hline
\end{tabular}

Fuel cost levelized over

2010 to:

all nuclear generation, mills/kwh

Fuel

less waste fee

Net fuel cost

H. I. waste repository

Total Levelized Fuel Cost

$\begin{array}{lllll}2030 & 2040 & 2050 & 2060 & 2070\end{array}$

$\begin{array}{lllll}2030 & 2040 & 2050 & 2060 & 2070\end{array}$

$\begin{array}{lllll}-1.13 & -0.75 & -0.17 & 0.62 & 1.51\end{array}$

$\begin{array}{llllll}-0.00 & 0.00 & 0.00 & 0.00 & 0.00\end{array}$

$\begin{array}{lllll}-1.13 & -0.75 & -0.17 & 0.62 & 1.51\end{array}$

$\begin{array}{llllll}0.31 & 0.45 & 0.47 & 0.47 & 0.40\end{array}$

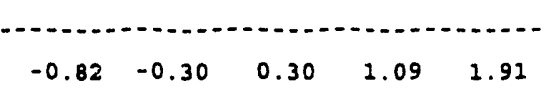

Decade Levelized Costs

Year Start

Year End

$\mathrm{mills} / \mathrm{kwh}$
2010- 2021- 2031- 2041- 2051- 2061-

$\begin{array}{llllll}2020 & 2030 & 2040 & 2050 & 2060 & 2070\end{array}$

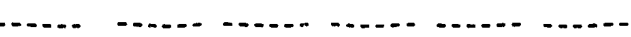

$\begin{array}{llllll}-0.76 & -0.89 & 0.92 & 2.75 & 6.01 & 9.72\end{array}$ 


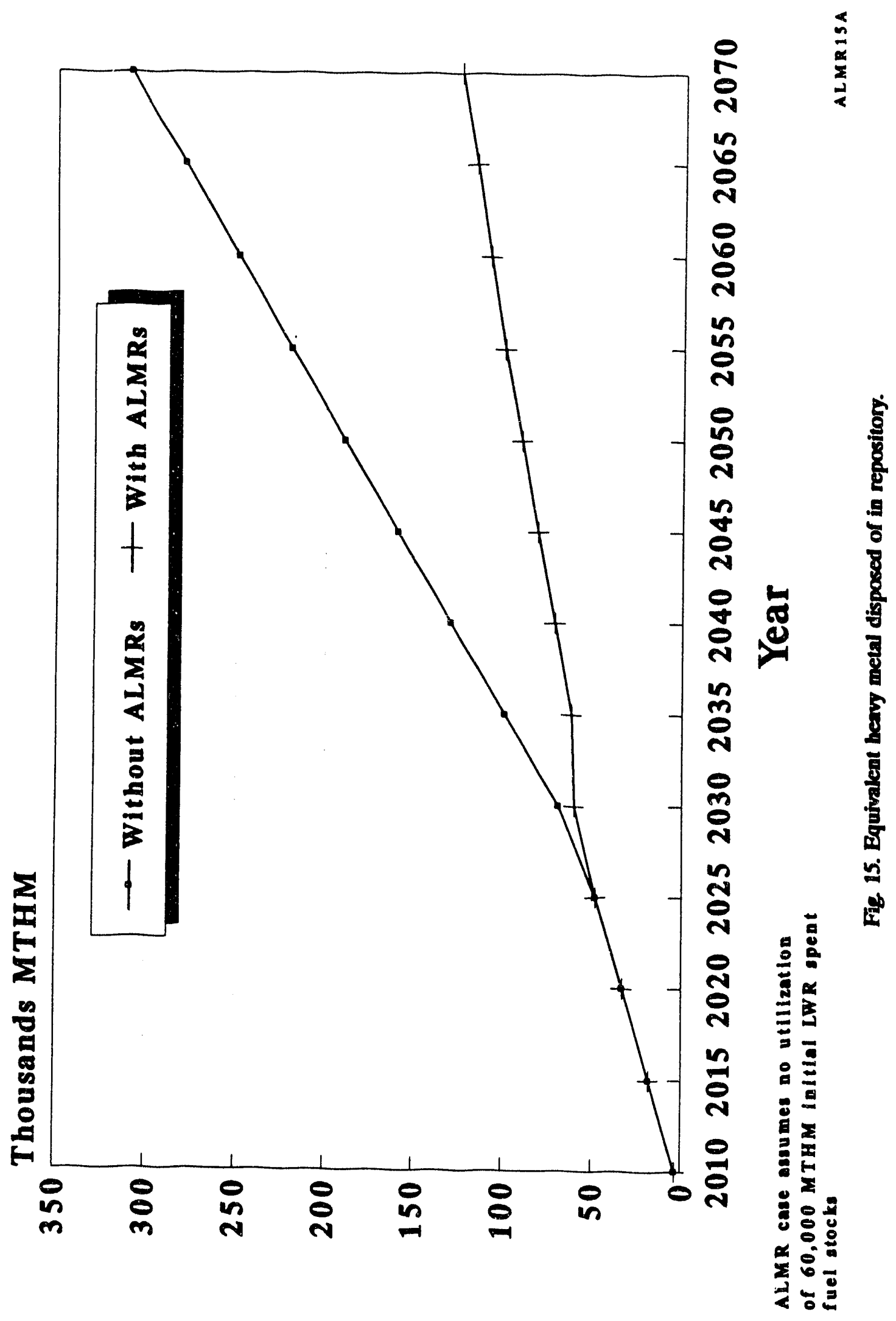


Table 45

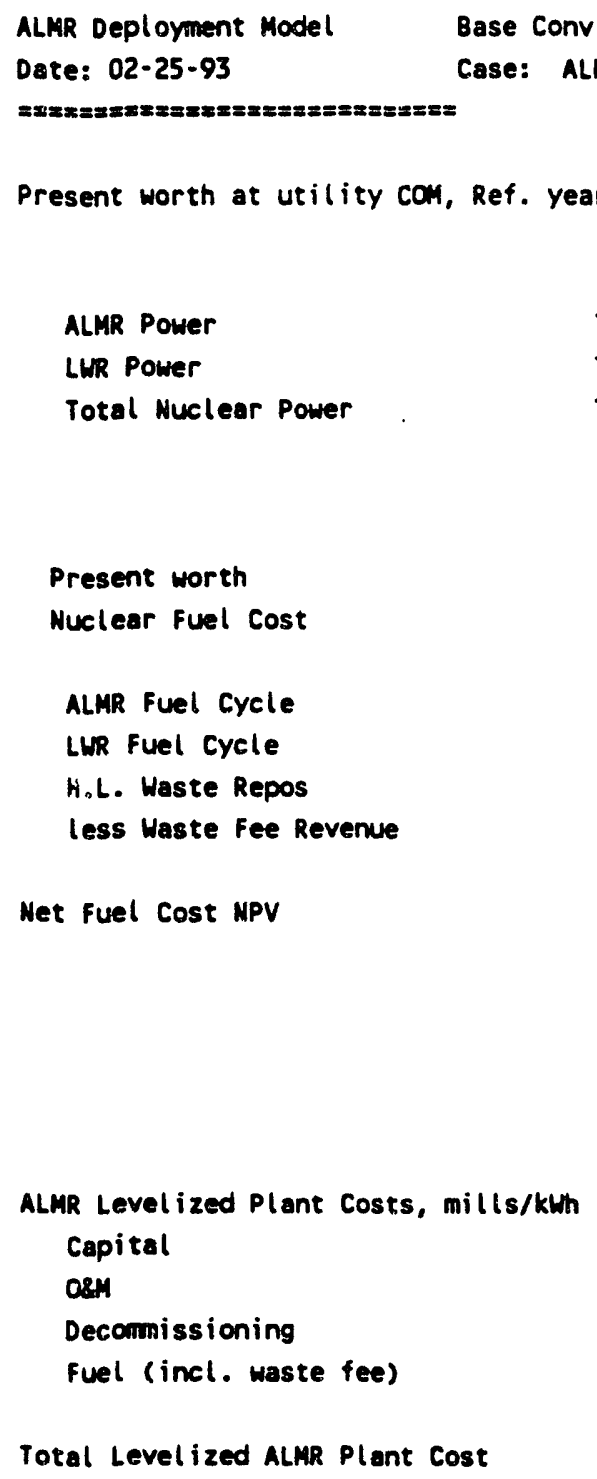

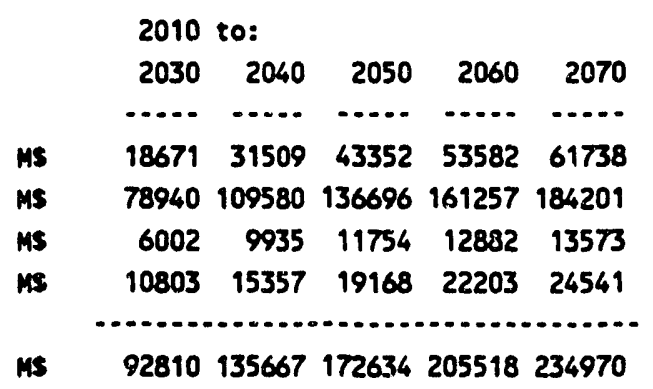

Fuel cost levelized over all nuclear generation, mills/kwh

Fuel

less waste fee

Net fuel cost

H. L. waste repository

TWh $\quad \begin{array}{llllll}1128 & 2081 & 3049 & 3918 & 4659\end{array}$

$\begin{array}{lrlllll}\text { TWh } & 9674 & 13276 & 16127 & 18285 & 19882 \\ \text { TWh } & 10803 & 15357 & 19168 & 22203 & 24541\end{array}$

$\begin{array}{rrrrrr}\text { TWh } & 9674 & 13276 & 16127 & 18285 & 19882 \\ \text { TWh } & 10803 & 15357 & 19168 & 22203 & 24541\end{array}$

2010 to:

$\begin{array}{lllll}2030 & 2040 \quad 2050 \quad 2060 \quad 2070\end{array}$

[....

92810135667172634205518234970

2010 to:

$\begin{array}{lllll}2030 & 2040 & 2050 & 2060 & 2070\end{array}$

$\begin{array}{llllll}\ldots . . . & \ldots . . . & \ldots . . . & \ldots . . . & \ldots . . .\end{array}$

$\begin{array}{lllll}31.6 & 27.2 & 24.1 & 21.9 & 20.4\end{array}$

$\begin{array}{lllll}9.0 & 8.5 & 8.4 & 8.3 & 8.2\end{array}$

$\begin{array}{lllll}1.2 & 1.2 & 1.2 & 1.2 & 1.2\end{array}$

$\begin{array}{lllll}16.5 & 15.1 & 14.3 & 13.7 & 13.2\end{array}$

$\begin{array}{lllll}58.4 & 52.1 & 47.9 & 45.1 & 43.1\end{array}$

Total Levelized fuel Cost

2010 to:

$\begin{array}{lllll}2030 & 2040 \quad 2050 \quad 2060 \quad 2070\end{array}$

....

$\begin{array}{lllll}9.04 & 9.19 & 9.39 & 9.68 & 10.02\end{array}$

$\begin{array}{lllll}1.00 & 1.00 & 1.00 & 1.00 & 1.00\end{array}$

$\begin{array}{llllll}8.04 & 8.19 & 8.39 & 8.68 & 9.02\end{array}$

$\begin{array}{lllll}0.56 & 0.65 & 0.61 & 0.58 & 0.55\end{array}$

Decade Levelized Costs

Year Start
Year End

$\begin{array}{lllll}8.59 & 8.83 & 9.01 & 9.26 & 9.57\end{array}$

2010-2021- 2031- 2041- 2051- 2061-

$\begin{array}{llllll}2020 & 2030 & 2040 & 2050 & 2060 & 2070\end{array}$

mills/kwh

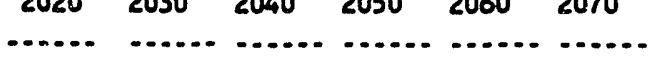




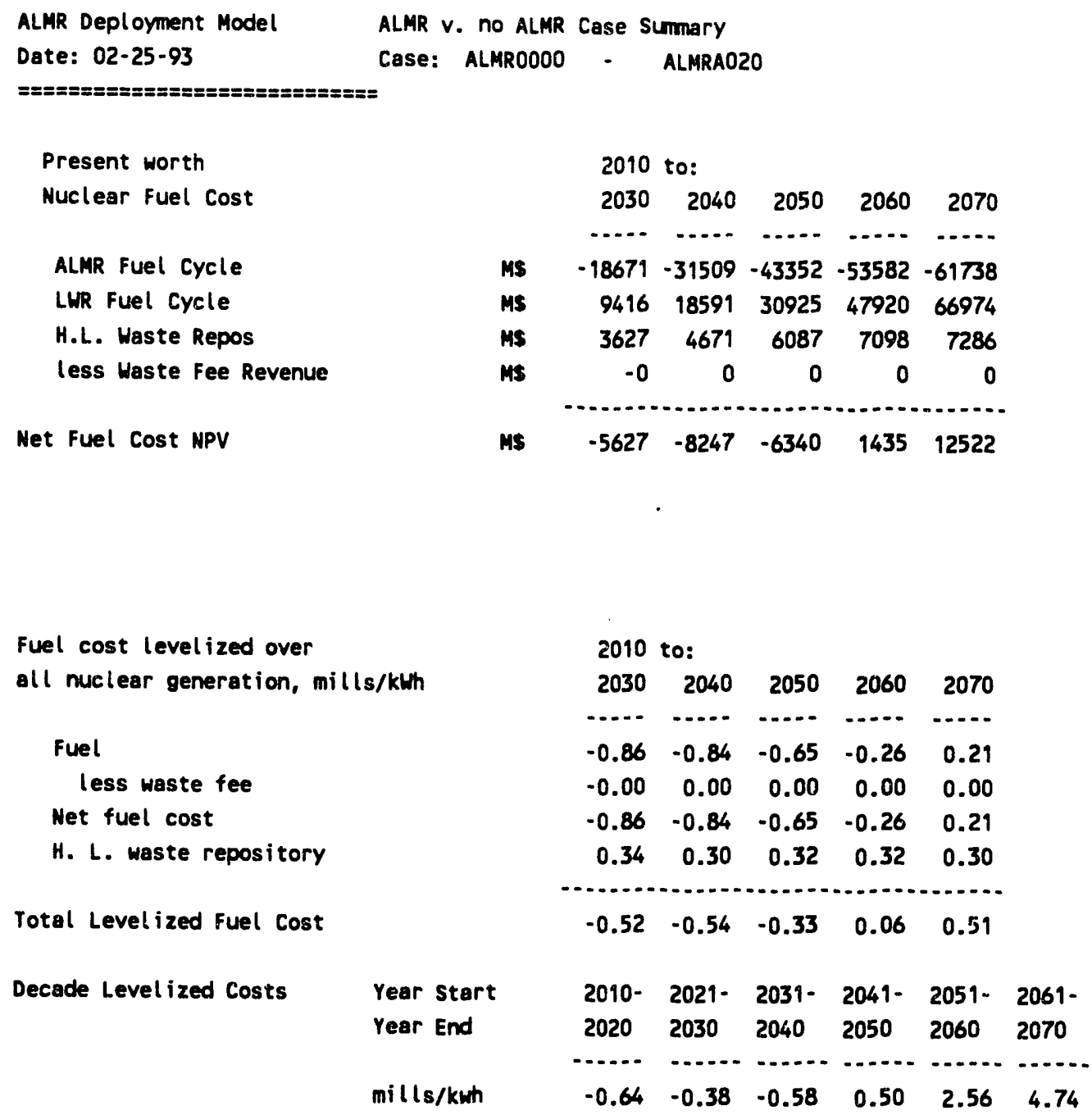




\section{REFERENCES}

1. Nuclear Energy Cost Data Base: A Reference Data Base for Nuclear and Coal-fired Powerplant Power Generation Cost Analysis, DOE/NE-0095 (September 1988).

2. ALMR Fuel Cycle Assessment-1991, GEFR-00898, GE Nuclear Energy (September 1991).

3. B. H. Hutchins, GE, personal communications with J. G. Delene, ORNL.

4. National Energy Strategy, Technical Annex 2, Integrated Analysis Supporting the National Energy Strategy: Methodology, Assumptions and Results, DOE/S-0086P, 1991/1992.

5. Review of 1991 Cost Estimate for the Advanced Liquid Metal Reactor, prepared by Oak Ridge National Laboratory for the U.S. Department of Energy (1992).

6. Personal communications from Y. I. Chang, ANL

7. Analysis of the Total System Life-Cycle Cost for the Civilian Radioactive Waste Management Program, DOE/RW-0236 (May 1989).

8. Allen G. Croff, A Concept for Increasing the Effective Capacity of a Unit Area of a Geological Repasitory, Oak Ridge National Laboratory Draft Report (December 8, 1992).

9. C. C. McPheeters and R. O. Pierce, Nuclear Waste from Phyrochemical Processing of LWR Spent Fuel for Actinide Recycle, ANL-IFR-165 (March 1992 draft).

10. World Nuclear Fuel Cycle Requirements 1991, DOE/ELA-0436 (91) (October 1991).

11. Uranium Industry Annual 1990, Energy Information Administration, DOE/EIA-0748 (90) (September 1991). 
ALMR0000 Null case with no ALMR deployment

ALMRA001" Base Case Scenario - Mod A burner with 86\% capacity factor, 27 GWe on line in $\mathbf{2 0 3 0}$

ALMRAO02 Base case with use of available defense Pu

ALMRA003 Base case with maximum possible ALMR deployment

ALMRAO04 Base case with 75\% capacity factor

ALMRAC05 Base case with $80 \%$ capacity factor

ALMRA006 Base case with \$200/kg LWR reprocessing cost

ALMRA007 Base case with S1000/kg LWR reprocessing cost

ALMRAC08 Base case with 0.5 waste equivalent mass factor

ALMRAOUy Base case with 0.5 repository disposal cost factor

ALMRA010 Base case with S15B cost for add-on repositories

ALMRA014 Base case with LWR reprocessing cost made part of waste system cost - 0 fissile cost to ALMR

ALMRA020 Base case without use of initial 60,000 MTHM LWR spent fuel

ALMRBO01 Mod A breakeven base case

ALMRBO03 Mod A breakeven case with maximum ALMR deployment

ALMRCO01 Mod B breeder base case

ALMRCO02 Mod B breeder with use of available defense Pu

ALMRC003 Mod B breeder with maximum ALAR deployment

\footnotetext{
- Fifth letter of name refers io particular fuel/core design:

ALMRA*** Mod A burner $(C . R=69)$.

ALMRB*: Mod A with breakeven fuel cycle (B.R.=1.04).

ALMRC".. Mod B breeder (B.R.=1.24).
} 


\section{Appendix B. SPREADSHEET ROW DESCRIPTIONS}

Bow Number

$1-44$

46-58

48

$50 *$

$51^{*}$

52

53

54

55

$57 *$

58

$60-165$

62

64-127

$128-130$

131

132

\section{Description}

Cost data and economic parameters. Those items marked with an asterisk "*" are input variables, other (non-marked) items are either fixed (such as 5 and 15 year tax depreciation schedules) or are calculated from other parameters.

ALMR deployment and power generation information.

Year

Full plants added in a given year (year on line 48).

Full plants removed from service in a given year (none shown in example calculation).

Number of ALMR plants on-line.

Reactor years of ALMR operation.

On-line ALMR capacity.

Energy generated by ALMRs in a given year.

Total nuclear generation in a given year.

The number of ALMR plants that can be added to the grid is constrained (not automatic in the present model) by the availability of fissile material. There must always be adequate fissile material available or an error (ERR) will appear in Cell "W5."

Nuclear power generated by sources other than ALMRs (assumed to be LWRs).

Capital Cost Model.

Capital investment cost at start-up for plants coming on-line in each year. There is learning until the fourth plant is reached which is assumed to be the NOAK plant.

Revenue requirements generated in each year for plants coming on-line in a specified year. This array uses year-by-year revenue requirements for the first commercial plants (lines 135-150) and for NOAK plants (lines 151-165).

Total revenue requirements for a given year in nominal (line 129) and constant (line 130) reference year dollars.

Average annual cost (constant \$) for capital in each year in Mills/kWh.

The levelized capital cost over the period from 2011 to 2050 in constant $\$$ mills/kWh. 
135-149 Year-by-year revenue requirements for FOAK ALMR plants normalized to S1 million initial investment (start of operation dollars).

151-165 Year-by-year revenue requirements for NOAK ALMR plants normalized to S1 million initial investment (start of operation dollars).

167-172 Annual O\&M costs. A learning factor is applied based on cumulative ALMR operating years (line 53).

174-180 Decommissioning cost for each year. No learning is assumed. Annual cost based on input decommissioning cost and sinking fund over plant book life.

181-301 Fuel cycle logistics and economies section.

184-186 ALMR driver assembly needs (line 186) for a full sized ALMR in each year relative to plant start-up (line 184). The initial core is assumed to be purchased one year before start-up and each reload is purchased at the beginning of the year in which it is needed.

188-200 Copy of lines 46-58.

The number of assemblies required in each year for initial cores.

205-265 The driver assemblies required in a given year for plant reloads for plants starting operation in a specified year.

Total reload driver assemblies required in each year.

269-272 Driver assemblies available for recycle with an assumed two-year (nominal) cooling period.

270 Driver assemblies becoming available for recycle in a given year. They lag discharge from the ALMR by two years in the current model.

271 Blanket assemblies available for recycle are also shown here, although all bookkeeping is done on driver assemblies since the ratio of blanket assemblies/driver assemblies is a coestant for recycle.

272 Net drivers available for reprocessing

= Old Balance - Drivers reprocessed during previous year (line 282)

+ Drivers becoming available this year (line 270).

274-301 ALMR Fuel Cycle Facility (FCF) Plants.

276-277 FCF plants started and shutdown in a given year.

Plant start-ups are input. The plants are assumed to have a 30-year life except for the first (25 MTHM/year) demo plant which is integrated into the first full size (nominally 200 MTHM/year) plant. Capacity additions are not automatic and are constrained by the availability of material to be recycled. 
Capital cost learning factor for FCF plants relative to FOAK FCF plant. Cumulative capital cost learning factor is specified in cell "AH32."

Fixed (capital) cost for FCF plants in a given year. This is based on FCF plant revenue requirements (lines 455-482), arriving at \& levelized annual constant $S$ cost for a nominal 200 MTHM/year FOAK FCF plant (cell "D485") escalated to the given year.

Driver assemblies reprocessed in given year. Blanket assemblies are assumed to be reprocessed along with these drivers.

Driver assemblies awaiting reprocessing at end of year.

Cumulative driver assemblies reprocessed from all FCF plants.

Number of driver assemblies that can be fabricated out of recovered material.

Labor learning based on cumulative driver assemblies reprocessed (line 284), and labor learning rate (cell "AH33").

290 Consumables learning based on cumulative driver assemblies reprocessed and consumables learning rate (cell "AH34").

Base consumables costs (Cell "AG25") adjusted for number of plants, inflation, and learning.

Driver assemblies, fabricated using recycled ALMR material, loaded into reactor. Drivers from recycle fuel are loaded first. Drivers from other alternative sources (e.g. defense plutonium) are next in line followed by drivers derived from LWR spent fuel actinides. Drivers are available first for makeup and then if any are left, for initial cores. Assemblies fabricated using material recovered during a given year is not assumed to be available for use until the end of the year.

End-of-year recycle assembly balance.

Costs in a given year are pro-rated to assemblies manufactured in that year. This gives a cost per assembly (before hardware costs).

LWR actinide recovery model.

LWR fuel actinide recovery plant start-ups. These additions are done manually in current model. Capacity additions must be such that adequate actinides are available for ALMR start-up and operation, but not so great as to use up the spent fuel inventory before the end of the plant life.

Plant shutdowns are automatic after plant book life is reached. 
On-line LWR fuel reprocessing capacity.

Cumulative LWR spent fuel mass reprocessed. Plants are assumed to run at full capacity output.

Fissile Pu recovered from spent $L W R$ fuel in a given year.

New LWR spent fuel becoming available for reprocessing in a given year.

Unreprocessed LWR spent fuel inventory.

Total fissile Pu (derived from LWR fuel) available for ALMR assemblies at beginning of year.

Equivalent driver assemblies that can be manufactured out of available $\mathrm{Pu}$.

Beginning of year inventory cost for fissile Pu inventory (based on cost of recovery and carrying charges on unused material).

Makeup and initial core driver assemblies manufactured in a given year using LWR spent fuel actinides.

Fissile $\mathrm{Pu}$ in driver assemblies derived from LWR spent fuel.

Cost per driver assembly from ALMR actinide source (before fabrication hardware).

LWR derived fissile Pu stockpile at end of year.

This line checks if enough fissile $\mathrm{Pu}$ is available to meet demand. If any value on line 306 is less than zero, an error ("ERR") will occur on this line and in cell "W5."

Assemblies derived from defense $\mathrm{Pu}$ source. Assemblies are manufactured until $\mathrm{Pu}$ used reaches the maximum available (cell "W11").

Unit assembly cost (before hardware cost) for assemblies derived from DP Pu. A plug number unit cost "W32" is assumed.

Assembly Fabrication. Fabrication labor, capital and consumables are assumed to be part of the reprocessing cost. Ha-dware cost is treated separately. Unit hardware cost will be the same no matter the source of the fissile material. Total driver (line 339) and blanket (line 341) assemblies fabricated are the sum of those from the 3 sources. Cinnulative assemblies fabricated are also estimated (lines 340 and 342). The hardware learning (line 343) is based on input learning factor (cell "AH35") and cumulative driver assemblies fabricated (line 340). The unit driver and blanket hardware costs (lines 344 and 345) are equal to the base input costs (cells "AG26" and "AG27") times the inflation escalation times the learning factor.

347-420 Fuel Cycle Revenue Requirements.

The amount paid in a given year for initial core fuel assemblies. 
The amount paid in a given year for reload fuel assemblies.

352-415 Fuel cycle revenue requirements in a given year for fuel assembly purchases for ALMR plant starting operation in a specific year.

Revenue requirements for assembly purchase (Nominal \$).

$418 \quad$ High-level waste fee (Nominal \$).

419-420 Total Revenue Requirements for ALM fuel cycle in each year in nominal and constant dollars.

Annual fuel cycle cost in Mills/kWh (constant S).

Levelized fuel cycle cost over the period from 2010-2050 (mills/kWh).

Year-by-year revenue requirements for initial core assemblies normalized to a \$1 million investment.

440-452 Year-by-year revenue requirements for reload core assemblies normalized to a $\$ 1$ million investment.

455-482 Revenue requirements calculation for FOAK FCF capital related costs.

Present worth of FCF plant capital related revenue requirements (cell D483).

D484-D487

Constant dollar levelized annual costs for a FOAK FCF by cost component.

D488-D493 Constant dollar per assembly levelized costs for a FOAK FCF by cost component.

495-536 Repository model.

Relative year for repository cash flows for capital, R\&D, siting, and regulatory costs for all repositories after first.

499 Cash flows (This information is presently not used).

501

Repeat of year.

Beginning of year cumulative non-reprocessed LWR spent fuel (same as line 314).

LWR spent fuel reprocessed during year (same as line 309).

$505 \quad$ LWR spent fuel assembly disposal during year.

Peak inventory of LWR spent fuel (before reprocessing or disposal) to date.

Un-reprocessed ALMR spent fuel inventory.

ALMR Spent fuel Reprocessed in year. 

two-year lag time between reprocessing and availability for disposal.

Repositories installed.

LWR Assembly capacity of all repositories commissions to date.

Reprocessing waste disposal in repository based on initial MTHM of fuel.

Equivalent LWR waste disposal. The additional repository capacity created by disposing of reprocessing wastes instead of full assemblies is accounted for here. If the repository can accommodate four times as much reprocessing wastes as spent fuel assemblies (0.25 factor in cell $\mathrm{AQ17}$ ) and there is no full assembly disposal (line 505), then the values on line 519 will be 0.25 times the numbers on line 509 .

Unused repository capacity in terms of full assembly LWR spent fuel disposal (initial MTHM).

High Level waste repository costs. Net present values for 2010-2050 are shown in Column D.

Pre-commissioning costs accounted for in year of repository commissioning. Note that first repository pre-2010 costs are not shown.

Fixed annual operating costs.

Variable operating cost. Cost proportional to quantity of material placed in repository.

Incremental costs associated with MRS.

Total cost for each year in nominal dollars. Cell "D527" is the Net Present Value of the costs from $2010-2050$.

Revenues from the $1 \mathrm{mill} / \mathrm{kwh}$ (escalated for inflation) high level waste disposal charge for all nuclear plants.

Cell "E536" gives the net present value (NPV) of the waste fee revenues from 2010-2050.

Cost summary table for ALMR deployment in 2010-2050 period. Both levelized cost and NPV are shown by cost component.

553-580 Uranium Fuel Model.

Annual uranium consumption for U.S. LWRs.

556 Curmulative U.S. uranium consumption from 1992 through date. Cell "E556" gives uranium consumption through 2009.

U.S. uranium price projected for given year. 
U.S. enrichment consumption for given year.

U.S. conversion for given year.

U.S. LWR Fuel Fabrication in given year.

562.567

Annual costs ior U.S. LWR fuel cycle components.

$570-571$

Total annual costs for U.S. LWR fuel on nominal and constant dollars.

C574-C580 Levelized LWR fuel cycle cost for 2010-2050 period in constant dollars.

583-646 Summary table.

588-593 Annual fuel cycle costs in nominal dollars.

593 Annual net fuel related costs for total nuclear system. Excludes high level waste fee but includes waste repository costs.

595-600 Present worth of nuclear power production by source for periods starting in 2010 and ending in years 2030, 2040, 2050, 2060, and 2070.

603-605 Present worth to 2010 (in reference years dollars) of ALMR capital, O\&M and decommissioning costs for same periods as for power (lines 598-600).

608-616 Present worth to 2010 (in reference years dollars) ALMR and LWR fuel costs, repository and waste fee for same periods as above. Net fuel cost includes repository cost but excludes waste fee.

623-629 Constant dollar levelized ALMR costs for periods starting in 2010 and ending in years 2030, 2040, 2050, 2060, and 2070. The fuel cost includes a 1 mill/kwh waste fee but excludes any direct repository costs or credits.

633-641 Levelized fuel cost for entire nuclear industry in constant dollars. Levelization periods are the same as above. The net fuel cost (line 638) excludes the waste fee and the total levelized cost includes the waste repository costs.

646 The levelized total fuel cost for decades starting in 2010 and ending in 2070.

649-682 A continuation of the LWR fuel cost model. This section takes a single LWR plant and calculates fuel cycle investments and revenue requirements for a 30-year period by cost component. Levelized costs were calculated for each component based on the input (cells AW14-AW17) commodity prices. The levelized cost, normalized to unit commodity price, is calculated in cells F677-F680. This normalized cost, together with the annual LWR power generation, commodity price in a given year, and inflation since reference year are used to calculate the annual fuel costs in line 563-566. The component fuel costs shown in cells D677-D680 were benchmarked against an AP-600 fuel cycle cost calculation using the PC version of the REFCO83 code and were found to be in excellent agreement. 
ORNL/TM-12344

Dist. Category UC-530

\section{Internal Distribution}

1. A. G. Croff

2-6. J. G. Delene

7. C. A. Forsberg

8. E. C. Fox

9-13. L. C. Fuller

14. W. J. Fulkerson

15. F. J. Homan

16-20. C. R. Hudson II

21. J. E. Jones Jr.

22 G. E. Michaels
23. R. L Reid

24. J. O. Steigler

25. C. L. Wagner

26. J. D. White

27. K. A. Williams

28. ORNL Patent Office

29. Central Research Library

30. Document Reference Section

31-32. Laboratory Records Department

33. Laboratory Records (RC)

\section{Extemal Distribution}

34. R. C. Berglund, General Electric Company, P.O. Box 530954, San Jose, CA 95153

35. L. F. Blankner, DOE-OR, P.O. Box 2001, Oak Ridge, TN 37831-8600.

36. E. C. Brolin, U.S. Department of Energy, NE.2, Washington, DC 20545

37. Y. I. Chang, Bldg. 208, Argonne National Laboratory, 9700 S. Cass Ave., Argonne, IL 60439

38. S. El Safwany, U.S. Department of Energy, San Francsico Operations Office, 1333 Broadway, Oakland, CA 94612

39. G. P. Eysymontt, AutEx, Inc., 7213 Chestnut St., Chevy Chase, MD 20815

40. L. K. Fletcher, DOE-Oak Ridge Operations, Oak Ridge, TN 37831

41. F. J. Goldner, U.S. Department of Energy, NE-45, Washington, DC 20545

42. J. N. Gonzaga, AutEx, Inc., 130 W. 67 St., Suite 1C, New York, NY 10023

43. J. Griffith, U.S. Department of Energy, NE-40, Washington, DC 20545

44. N. Grossman, U.S. Department of Energy, NE-45, Washington, DC 20545

45. P. B. Hemmig, U.S. Department of Energy, NE-462, Washington, DC 20545

46. B. A. Hutchins, General Electric Company, P.O. Box 530954, San Jose, CA 95153

47. J. D. Nulton, U.S. Department of Energy, NE-40, Washington, DC 20545

48. J. E. Quinn, General Electric Company, P.O. Box 530954, San Jose, CA 95153

49. E Rodwell, Electric Power Research Institute, P.O. Box 10412, Palo Alto, CA 94303

50. H. H. Rohm, U.S. Department of Energy, NE-40, Washington, DC 20545

51. C. R. Snyder, Bechtel National Incorporated, P.O. Box 3965, San Francisco, CA 94119

52. W. M. Sprecher, U.S. Department of Energy, RW-4, Washington, DC 20585

53. M. L. Thompson, General Electric Company, P.O. Box 530954, San Jose, CA 95153

54. C. E. Webber, U.S. Department of Energy, NE-14, Washington, DC 20545

55. John Williams, U.S. Department of Energy, NE-40, Washington, DC 20545

56. J. J. Zucchetto, National Academy of Sciences, 2101 Constitution Ave., NW, Washington, DC 20418

57. Office of Assistant Manager for Energy Research and Development, DOE-Oak Ridge Operations, Oak Ridge, TN 37831

58-114. Given distribution as shown in DOE/OSTI-4500-R75 under category UC-530 (Liquid Metal Fast Breeder Reactors) 

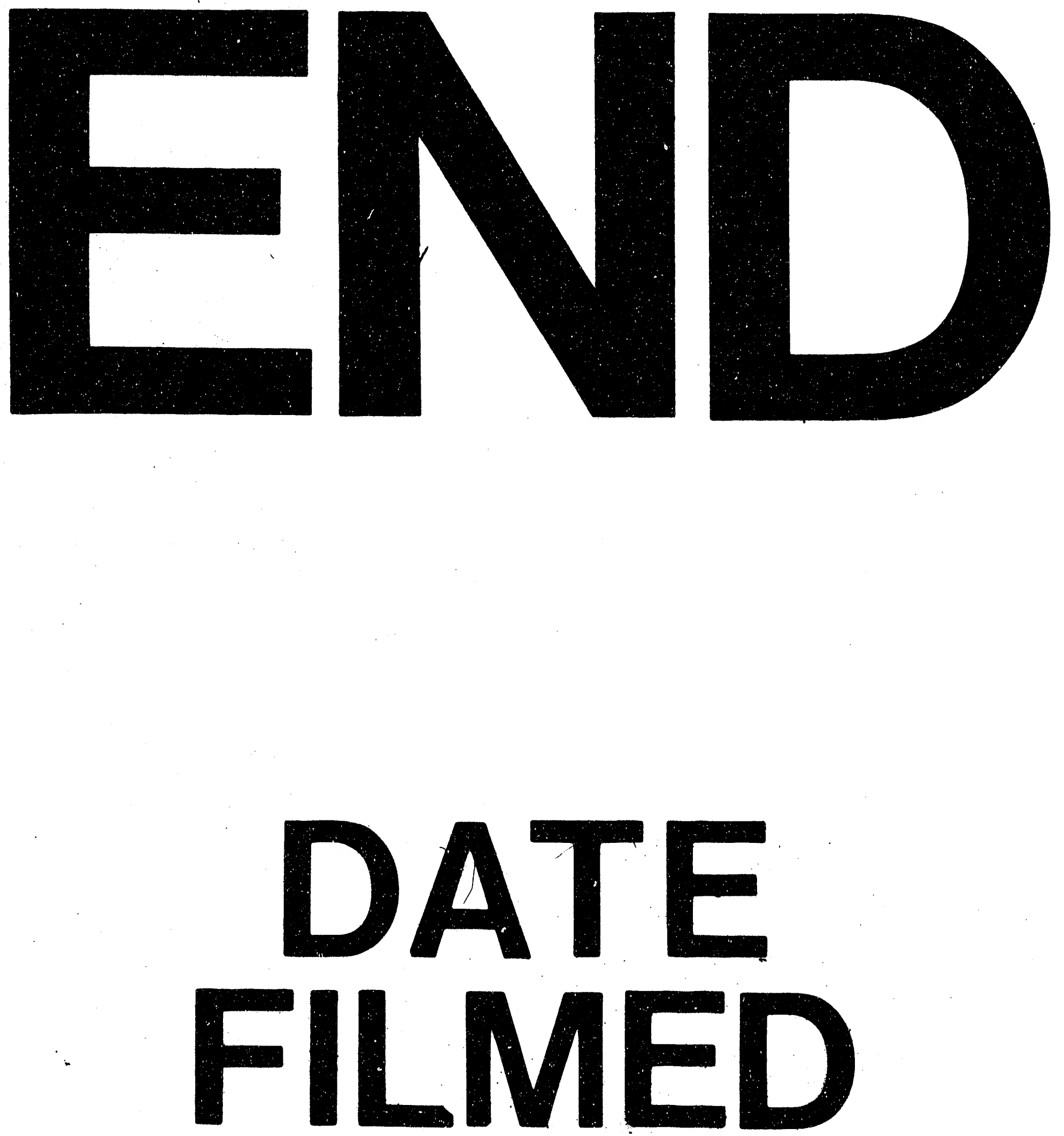

1

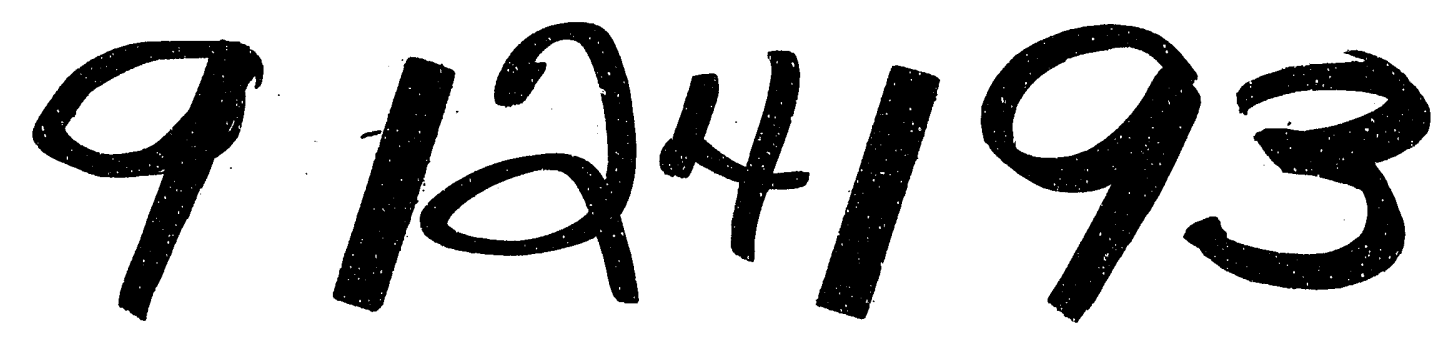


